
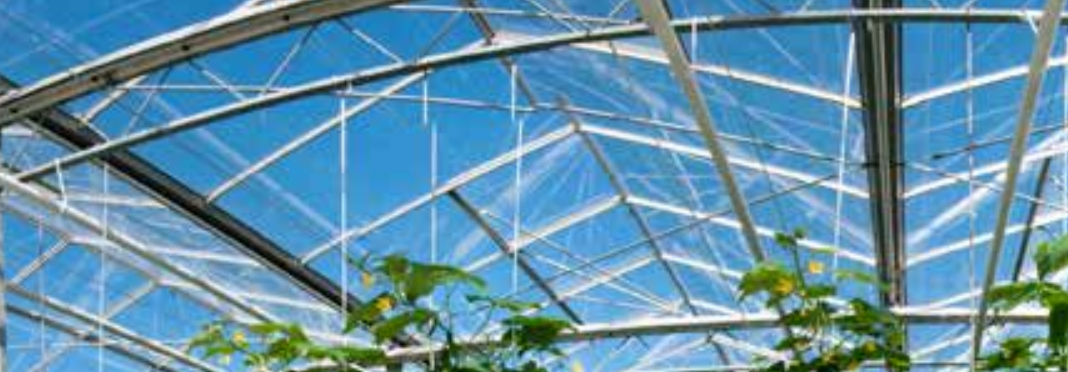

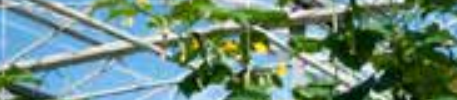

Energiemonitor van de Nederlandse glastuinbouw 2020 



\section{Energiemonitor van de Nederlandse glastuinbouw 2020}

Pepijn Smit en Nico van der Velden

Dit onderzoek is uitgevoerd door Wageningen Economic Research in opdracht van de Stichting Kennis in je Kas van de glastuinbouwsector en met subsidie van het Ministerie van Landbouw, Natuur en Voedselkwaliteit. 
Smit, Pepijn en Van der Velden, Nico, 2021. Energiemonitor van de Nederlandse glastuinbouw 2020. Wageningen, Wageningen Economic Research, Rapport 2021-127. 60 blz.; 25 fig.; 6 tab.; 14 ref.

Tussen de Nederlandse glastuinbouwsector en overheid is een doel voor de $\mathrm{CO}_{2}$-emissie in 2020 afgesproken. In 2017 is dit doel technisch gecorrigeerd van 6,2 naar 4,6 Mton. In 2020 steeg de $\mathrm{CO}_{2-}$ emissie naar 6,1 Mton en lag hiermee wel onder het oorspronkelijke doel uit 2014, maar boven het actuele doel na technische correctie uit 2017. Uit onderzoek van Wageningen Economic Research (2021) is gebleken dat recente ontwikkelingen aanleiding geven een nieuwe technische correctie van het doel voor 2020 te overwegen.

In 2020 steeg de $\mathrm{CO}_{2}$-emissie vooral door toename van het areaal, maar ook doordat er meer elektriciteit verkocht werd en de inkoop van niet-duurzame warmte afnam. De groei van duurzame energie en van inkoop elektriciteit compenseerden een deel van deze stijging. De energie-efficiëntie verslechterde in 2019 met 1 procentpunt. Het aandeel duurzame energie groeide naar 10,4\%. Het aandeel van energievoorzieningen zonder $\mathrm{CO}_{2}$-emissie voor de glastuinbouw (duurzame energie, inkoop warmte en inkoop elektriciteit) kwam in 2020 op 22,5\%, bijna een verdubbeling sinds 2010.

Trefwoorden: Glastuinbouw, energie, $\mathrm{CO}_{2}$-emissie, emissiereductie, energietransitie, energievoorziening, energie-efficiëntie, duurzame energie, warmtekrachtkoppeling

Dit rapport is gratis te downloaden op https://doi.org/10.18174/555540 of op www.wur.nl/economicresearch (onder Wageningen Economic Research publicaties).

(C) 2021 Wageningen Economic Research

Postbus 29703, 2502 LS Den Haag, T 07033583 30, E communications.ssg@wur.nl, www.wur.nl/economic-research. Wageningen Economic Research is onderdeel van Wageningen University \& Research.

\section{(cc) BY-NC}

Dit werk valt onder een Creative Commons Naamsvermelding-Niet Commercieel 4.0 Internationaallicentie.

(C) Wageningen Economic Research, onderdeel van Stichting Wageningen Research, 2021 De gebruiker mag het werk kopiëren, verspreiden en doorgeven en afgeleide werken maken. Materiaal van derden waarvan in het werk gebruik is gemaakt en waarop intellectuele eigendomsrechten berusten, mogen niet zonder voorafgaande toestemming van derden gebruikt worden. De gebruiker dient bij het werk de door de maker of de licentiegever aangegeven naam te vermelden, maar niet zodanig dat de indruk gewekt wordt dat zij daarmee instemmen met het werk van de gebruiker of het gebruik van het werk. De gebruiker mag het werk niet voor commerciële doeleinden gebruiken.

Wageningen Economic Research aanvaardt geen aansprakelijkheid voor eventuele schade voortvloeiend uit het gebruik van de resultaten van dit onderzoek of de toepassing van de adviezen.

Wageningen Economic Research is ISO 9001:2015 gecertificeerd.

Wageningen Economic Research Rapport 2021-127 | Projectcode 2282200621

Foto omslag: Shutterstock 


\section{Inhoud}

Woord vooraf $\quad 5$

$\begin{array}{ll}\text { Samenvatting } & 6\end{array}$

S.1 $\mathrm{CO}_{2}$-emissie glastuinbouw in 2020 gestegen $\quad 6$

S.2 Energiegebruik en -voorziening glastuinbouw in beweging 7

$\begin{array}{lll}\text { S.3 Werkwijze Energiemonitor } & 8\end{array}$

$\begin{array}{ll}\text { Summary } & 9\end{array}$

S.1 $\mathrm{CO}_{2}$ emissions from greenhouse horticulture increased in $2020 \quad 9$

S.2 Energy consumption and energy sources in greenhouse horticulture in motion 10

$\begin{array}{ll}\text { S.3 Method Energy Monitor } & 11\end{array}$

1

Inleiding

1.1 Energiemonitor van de Nederlandse glastuinbouw biedt inzicht

1.2 Meerjarenafspraak Energietransitie Glastuinbouw en programma Kas als Energiebron

1.3 Glastuinbouw, energie en $\mathrm{CO}_{2}$-emissie continu in ontwikkeling

2.1 Totale $\mathrm{CO}_{2}$-emissie en $\mathrm{CO}_{2}$-emissie teelt per $\mathrm{m}^{2}$ gestegen 15

$\begin{array}{lll}2.2 & \text { Energie-efficiëntie verslechterd } & 17\end{array}$

$\begin{array}{lll}2.3 & \text { Aandeel duurzame energie gegroeid } & 19\end{array}$

2.4 Kwantitatieve analyse ontwikkeling $\mathrm{CO}_{2}$-emissie $\quad 20$

$\begin{array}{lll}2.5 & \text { Energiekosten gedaald } & 22\end{array}$

$\begin{array}{lll}2.6 & \text { Energiegebruik toegenomen } & 23\end{array}$

3.1 Duurzame energie is vanuit meerdere hoeken te belichten 25

3.2 Inzet duurzame energiebronnen bleef in beweging 25

3.2.1 Totale inzet duurzame energiebronnen groeit door $\quad 25$

3.2.2 Ontwikkelingen verschillen sterk per duurzame energiebron 26

3.2.3 Stijging van productie, inkoop, verkoop en consumptie duurzame energie 29

3.2.4 Bijna $20 \%$ van het glastuinbouwareaal gebruikt duurzame energie $\quad 30$

$3.3 \mathrm{CO}_{2}$-emissiereductie door duurzame energie in 2020 verder gegroeid 32

3.4 Warmtedekking vaak beperkt tot basislast 33

4.1 Inzet wkk heeft ook buiten de glastuinbouw effect 36

4.2 Gelijke productie wkk, minder eigen toepassing en meer verkoop 36

4.3 Elektriciteitsbalans toont verschuiving van toepassing uit eigen productie naar $\begin{array}{ll}\text { verkoop } & 38\end{array}$

4.4 Inkoop van niet-duurzame warmte wederom gedaald 40

4.5 Effect inzet wkk en inkoop warmte op de $\mathrm{CO}_{2}$-emissie $\quad 41$

5.1 Emissiereductie en energietransitie langs twee hoofdlijnen 43

5.2 Aandeel energievoorzieningen zonder $\mathrm{CO}_{2}$-emissie gegroeid en beheer aan het verschuiven

5.3 Inkoop $\mathrm{CO}_{2}$ licht gedaald door leveringsonderbreking $\quad 44$ 
$\begin{array}{ll}\text { Bronnen en literatuur } & \mathbf{4 8}\end{array}$

Bijlage 1 Definities, methode en bronnen 49

Bijlage 2 Kenmerken en energie-indicatoren glastuinbouw 53

Bijlage 3 Energiegebruik glastuinbouw (totaal glastuinbouwareaal en niet gecorrigeerd voor temperatuur) a)

54

Bijlage 4 Gebruik en $\mathrm{CO}_{2}$-emissiereductie per duurzame energiebron

Bijlage 5 Inkoop externe $\mathrm{CO}_{2}$, gebruik en $\mathrm{CO}_{2}$-emissiereductie wkk en inkoop van warmte

Bijlage 6 Effecten aanpassingen areaal CBS Landbouwtelling op de Energiemonitor 


\section{Woord vooraf}

Voor de Nederlandse glastuinbouw is energie een belangrijk productiemiddel. Energie geproduceerd met fossiele brandstof brengt $\mathrm{CO}_{2}$-emissie met zich mee en dat versterkt het broeikaseffect. Tussen de glastuinbouw en de overheid is in de Meerjarenafspraak Energietransitie Glastuinbouw 2014-2020 een $\mathrm{CO}_{2}$-doelstelling voor 2020 voor de glastuinbouw overeengekomen. Hiermee kwam reductie van de $\mathrm{CO}_{2}$-emissie centraal te staan in het energiebeleid van de glastuinbouw. In het programma Kas als Energiebron werken Glastuinbouw Nederland (GTNL) en het ministerie van Landbouw, Natuur en Voedselkwaliteit (LNV) samen om de $\mathrm{CO}_{2}$-doelstelling te realiseren.

De oorspronkelijke $\mathrm{CO}_{2}$-doelstelling voor 2020 in de Meerjarenafspraak was 6,2 Mton. In 2017 werd de doelstelling technisch gecorrigeerd naar 4,6 Mton. Uit onderzoek van Wageningen Economic Research uit 2021 is gebleken dat recente ontwikkelingen van aanpassing van het areaal in de Landbouwtelling (CBS) en groei van de verkoop van elektriciteit (beide externe factoren) aanleiding geven een nieuwe technische correctie te overwegen. In juli 2021 heeft de Minister van LNV dit onderzoek gedeeld met de Tweede Kamer.

Om realistische keuzes te kunnen maken, is het voor de overheid en het glastuinbouwbedrijfsleven belangrijk de werkelijke ontwikkelingen met hun achtergronden in beeld te hebben. De Energiemonitor van de Nederlandse Glastuinbouw kwantificeert, analyseert en duidt de ontwikkeling van het energiegebruik en bijbehorende energie-indicatoren.

Voor velen was 2020 door de coronapandemie een bijzonder jaar. Ook in de glastuinbouwsector heeft men moeten reageren op de effecten hiervan op de markt voor tuinbouwproducten en de energiemarkt. Hiernaast was 2020 een bijzonder jaar voor de convenantpartners GNL en LNV omdat hun meerjarenafspraak afliep. Aan nieuwe afspraken wordt nog gewerkt. Met historisch hoge energieprijzen zal ook het jaar 2021 een bijzonder jaar voor de Nederlandse glastuinbouwsector kunnen gaan worden.

Voor de Energiemonitor was 2020 ook een bijzonder jaar, omdat dit de laatste editie is met de bezielende medewerking van Nico van der Velden. Wij danken Nico voor de doorlopende ontwikkeling van de Energiemonitor, het ontsluiten van de noodzakelijke data, zijn nieuwsgierigheid naar het verhaal bij de cijfers en een goede relatie met de opdrachtgevers en bronnen. Nico vormde al lang een team met Pepijn Smit en draagt met deze editie aan hem de projectleiding over.

Wageningen Economic Research maakt de Energiemonitor van de Nederlandse glastuinbouw in opdracht van de Stichting Kennis in je Kas van de glastuinbouwsector en met subsidie van het ministerie van LNV in het kader van Kas als Energiebron. De begeleidingscommissie bestond uit Piet Broekharst (Glastuinbouw Nederland), Klaas de Vries (LNV) en Olaf Hietbrink (Wageningen Economic Research). Vele partijen hebben informatie aangeleverd; hiervan is dankbaar gebruikgemaakt.

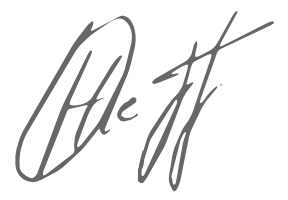

Ir. O. (Olaf) Hietbrink

Business Unit Manager Wageningen Economic Research Wageningen University \& Research 


\section{Samenvatting}

\section{S.1 $\mathrm{CO}_{2}$-emissie glastuinbouw in 2020 gestegen}

In 2020 steeg de totale $\mathrm{CO}_{2}$-emissie van de glastuinbouw naar 6,1 Mton. Er was net als in 2019 een stijging van 0,2 Mton. Hiermee lag de emissie boven het actuele doel na technische correctie uit 2017 (4,6 Mton), maar onder het oorspronkelijke doel uit 2014 (6,2 Mton). Onderzoek van Wageningen Economic Research uit 2021 heeft aangetoond dat recente ontwikkelingen aanleiding geven een nieuwe technische correctie te overwegen. De totale $\mathrm{CO}_{2}$-emissie was $11 \%$ lager in vergelijking met 1990.

De toename van de $\mathrm{CO}_{2}$-emissie in 2020 kwam doordat emissie-stuwende factoren samen een groter effect hadden dan emissie-verlagende factoren. De factoren die de $\mathrm{CO}_{2}$-emissie deden toenemen in 2020 waren de verdere toename van het areaal in de Landbouwtelling, de stijging van de elektriciteitsverkoop met wkk, de afname van de inkoop niet-duurzame warmte en de toename van het energiegebruik per $\mathrm{m}^{2}$. De factoren die de $\mathrm{CO}_{2}$-emissie verlaagden waren de groei van de inzet van duurzame energie en de groei van de inkoop elektriciteit.

De $\mathrm{CO}_{2}$-emissie van de teelt per $\mathrm{m}^{2}$ na temperatuurcorrectie steeg in 2020 met 0,3 kg naar 45,7 kg $\mathrm{CO}_{2}$. Deze stijging $(+0,7 \%)$ is minder dan de stijging van de totale $\mathrm{CO}_{2}$-emissie zonder temperatuurcorrectie $(+3,3 \%)$. Dit komt doordat deze eerste indicator onafhankelijk is van de buitentemperatuur, het areaal en de elektriciteitsverkoop en juist de laatste twee hadden in 2020 de grootste invloed op de stijging van de totale $\mathrm{CO}_{2}$-emssie. Hieruit blijkt dat de stijging van de totale $\mathrm{CO}_{2}$-emissie in 2020 vooral voortkwam uit factoren waarop de glastuinbouw minder invloed heeft.

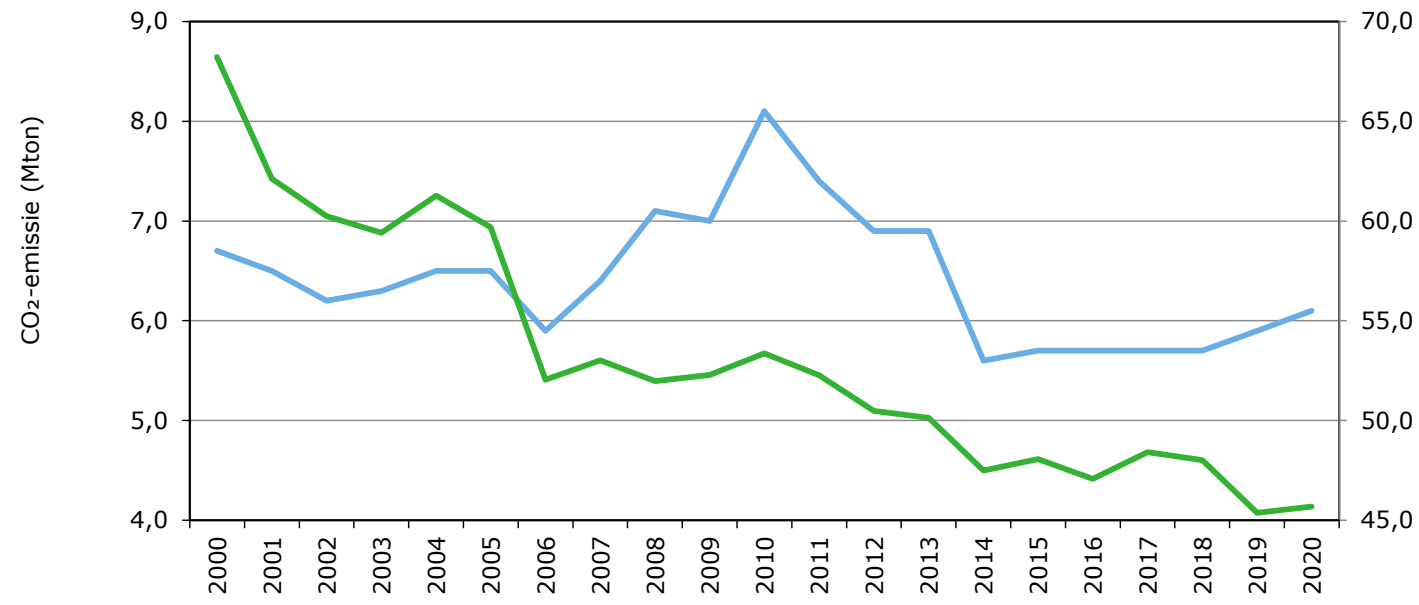

Figuur S.1 Totale $\mathrm{CO}_{2}$-emissie en $\mathrm{CO}_{2}$-emissie teelt na temperatuurcorrectie per $m^{2}$ per jaar van de Nederlandse glastuinbouw $v$ )

v) Cijfers 2020 voorlopig. 


\section{S.2 Energiegebruik en -voorziening glastuinbouw in beweging}

\section{Energiegebruik toegenomen}

Het totaal energiegebruik steeg in 2020 naar 110 PJ. Deze stijging kwam vooral door toename van het areaal in de Landbouwtelling. Het energiegebruik per $\mathrm{m}^{2}$ was met $1,1 \mathrm{GJ} / \mathrm{m}^{2}$ ten opzichte 2019 weliswaar globaal stabiel, maar het aandeel elektriciteit in het energiegebruik daalde van 26 naar $24 \%$. Deze daling kwam mede voort uit de effecten van coronamaatregelen (incidenteel effect) en de hogere ODE-heffing op elektriciteit (structureel effect).

Groei energievoorzieningen zonder $\mathrm{CO}_{2}$-emissie inclusief duurzame energie zet door Het aandeel van de energievoorzieningen zonder $\mathrm{CO}_{2}$-emissie in de glastuinbouw groeide in 2020 met een half procentpunt naar $22,5 \%$. Sinds 2010 is dit aandeel bijna verdubbeld. Het aandeel duurzame energie hierbinnen nam in 2020 toe met bijna 1 procentpunt naar 10,4\%.

De totale hoeveelheid toegepaste duurzame energie groeide van 10,0 naar 11,5 PJ. Iets meer dan helft van de hoeveelheid energie uit voorzieningen zonder $\mathrm{CO}_{2}$-emissie betrof warmte, iets minder dan de helft elektriciteit. Bij het deel warmte wordt circa de helft door de glastuinbouw zelf opgewekt en de andere helft ingekocht bij partijen van buiten de sector. Hierbij is aardwarmte de belangrijkste warmtebron. Het deel elektriciteit wordt hoofdzakelijk ingekocht.

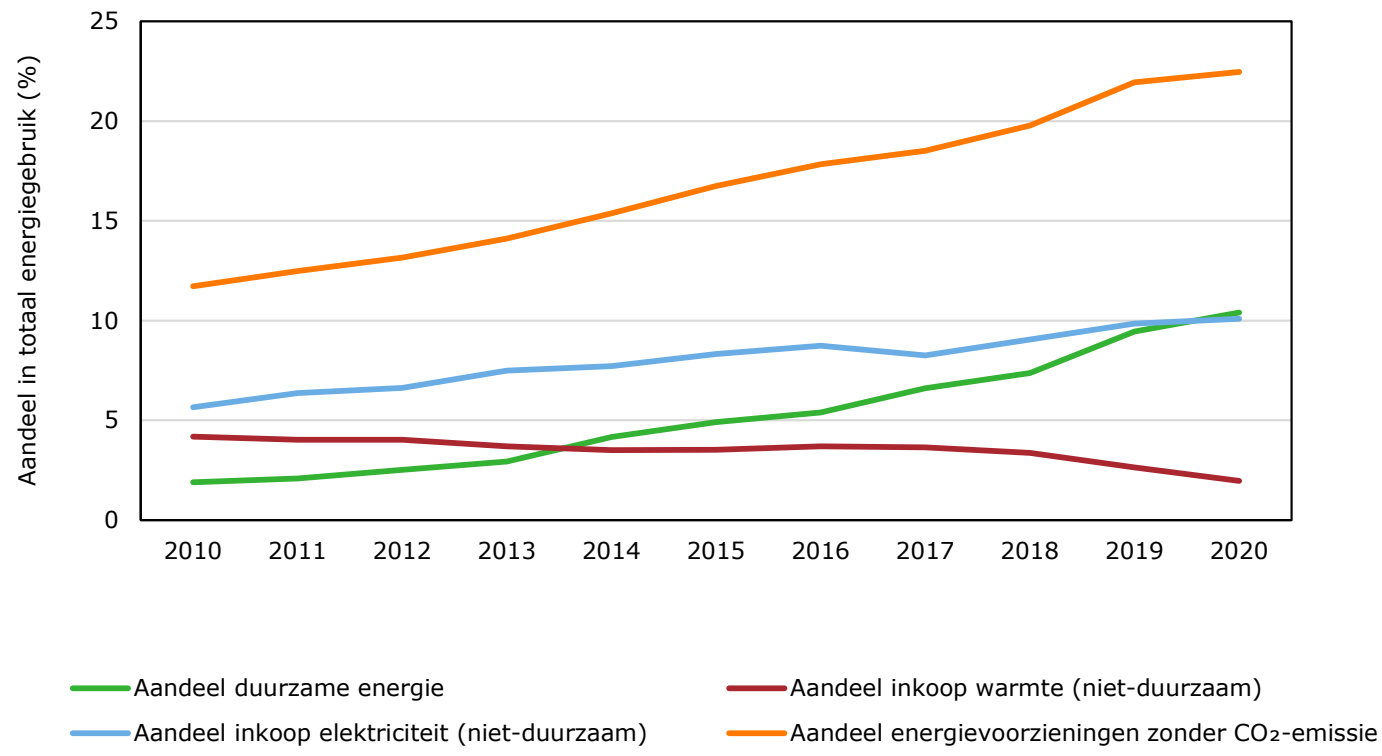

Figuur S.2 Ontwikkeling van het aandeel van energievoorzieningen zonder $\mathrm{CO}_{2}$-emissie voor de glastuinbouwsector 2010-2020 v)

v) Cijfers 2020 voorlopig.

Inzet aardgas wkk licht verschoven

Productie van elektriciteit met aardgas wkk was met 10,3 miljard kWh in 2020 iets lager in vergelijking met 2019 (-1\%). Wel was er in 2020 een verschuiving van eigen consumptie van geproduceerde elektriciteit naar verkoop die mede voortkwam uit de effecten van coronamaatregelen en de gemiddeld gunstige sparkspread; het verschil tussen de prijs van de input (aardgas) en de output (elektriciteit).

Door de inzet van wkk's in de glastuinbouw lag in 2020 de $\mathrm{CO}_{2}$-emissie van de glastuinbouw 2,8 Mton hoger, maar werd er buiten de glastuinbouw 4,4 Mton $\mathrm{CO}_{2}$-emissie vermeden. Dit betekent een nationale reductie door wkk in de glastuinbouw van 1,6 Mton. 


\section{S.3 Werkwijze Energiemonitor}

In de Energiemonitor glastuinbouw worden jaarlijks de energie-indicatoren $\mathrm{CO}_{2}$-emissie, energieefficiëntie en aandeel duurzame energie gekwantificeerd. Hiervoor worden de energiebalans en de fysieke productie in kaart gebracht en samen met de indicatoren en achtergronden geanalyseerd en geduid in de context van de ontwikkelingen. Voor deze monitor is een methodiek ontwikkeld waarin sectordeskundigen een reeks van informatiebronnen combineren. De methodiek is vastgelegd in een protocol dat naast de Energiemonitor wordt gepubliceerd. 


\section{Summary}

\section{S.1 $\mathrm{CO}_{2}$ emissions from greenhouse horticulture increased in 2020}

In 2020 the total $\mathrm{CO}_{2}$ emissions of Dutch greenhouse horticulture have risen to 6.1 Mtonne in 2020. The increase by 0.2 Mton was equal to that of 2019 . With this the total $\mathrm{CO}_{2}$ emissions were above the current target after technical correction (4.6 Mton), but under the original target for 2020 (6.2 Mtonne). Research by Wageningen Economic Research from 2021 has indicated that recent developments give cause to consider a new technical correction. The total $\mathrm{CO}_{2}$ emissions were at a $11 \%$ lower level compared to 1990 .

The increase of $\mathrm{CO}_{2}$ emissions in 2020 was caused by emission-pushing factors having a larger effect than emission-damping effects. The factors pushing the total $\mathrm{CO}_{2}$ emissions were further growth of crop area in the Agricultural Census (LBT), the increase of electricity sale from gas engines (CHP), the drop in purchase of non-sustainable heat from third parties and the increase of the energy consumption per $\mathrm{m}^{2}$. Factors that lowered the $\mathrm{CO}_{2}$ emissions were the growth of renewable energy consumption and the increase of electricity purchase. This proves that the increase of total $\mathrm{CO}_{2}$ emissions was caused by factors mostly outside the influence of the greenhouse sector.

$\mathrm{CO}_{2}$ emissions for crop growth per $\mathrm{m}^{2}$ after temperature correction increased in 2020 with $0.3 \mathrm{~kg}$ to $45.7 \mathrm{~kg} \mathrm{CO}$. This increase $(+0.7 \%)$ is less compared to the increase of the total $\mathrm{CO}_{2}$ emissions without temperature correction $(+3.3 \%)$. This is due to the first indicator being independent from outside temperature, crop area and electricity sale and these last two had a major impact on the total $\mathrm{CO}_{2}$ emissions.

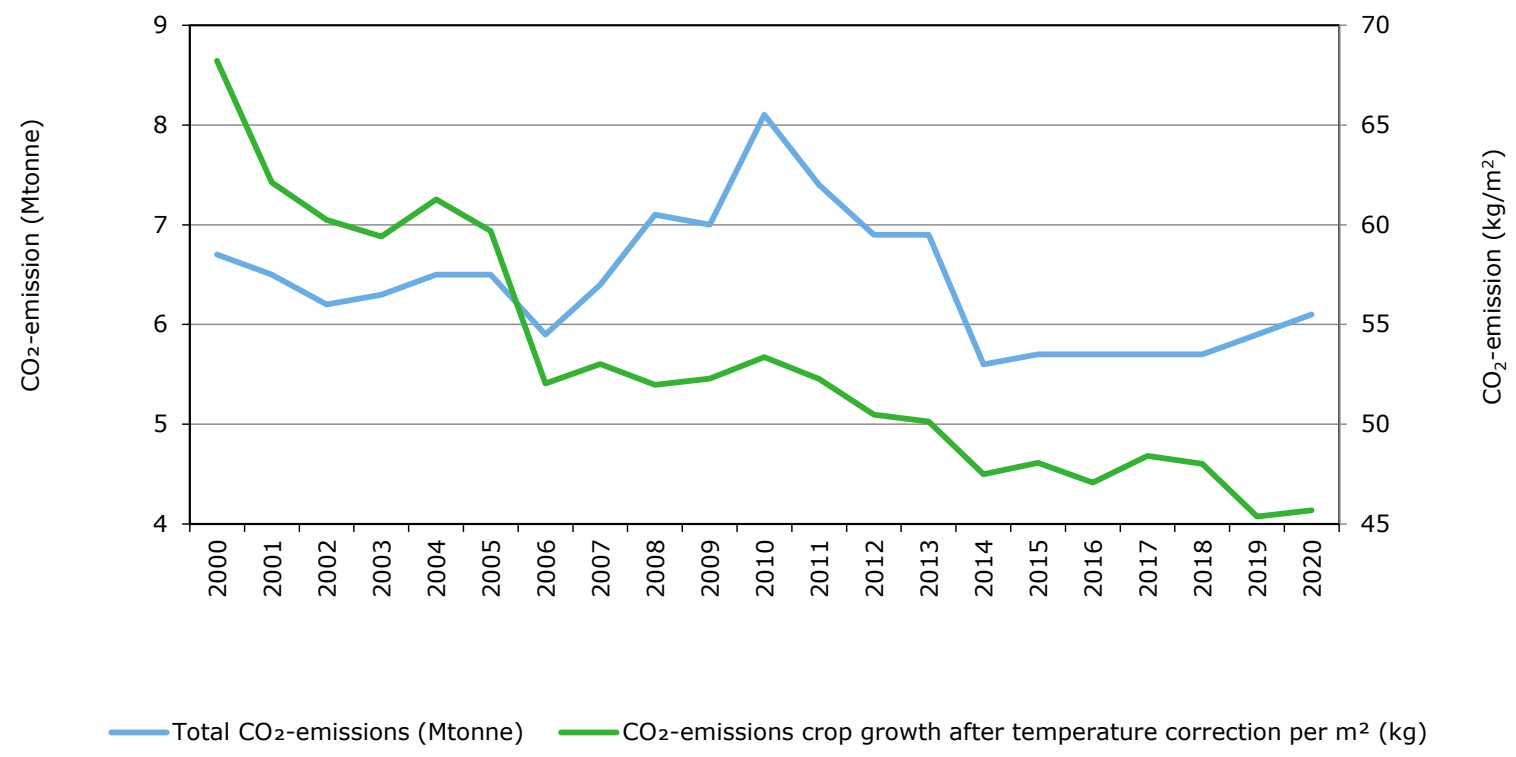

Figure S.1E Total $\mathrm{CO}_{2}$ emissions and $\mathrm{CO}_{2}$ emissions for crop growth per $\mathrm{m}^{2}$ after temperature correction per year of Dutch greenhouse horticulture $v$ )

v) Results for 2020 are provisional. 


\section{S.2 Energy consumption and energy sources in greenhouse horticulture in motion}

Energy consumption has increased

The total consumption of energy has in 2020 increased to $110 \mathrm{PJ}$. This growth was mostly caused by the increase of area in the LBT. Although the energy consumption per $\mathrm{m}^{2}$ was stable compared to 2019 at $1.1 \mathrm{GJ} / \mathrm{m}^{2}$, the share of electricity in energy consumption fell from $26 \%$ to $24 \%$. This decrease was mostly due to the effects of corona measures (incidental effect) and higher ODE taxes on electricity (structural effect).

Growth of energy sources without $\mathrm{CO}_{2}$ emissions including renewable energy continues The share of energy sources without $\mathrm{CO}_{2}$ emissions for the greenhouse horticulture sector increased by half a percent-point to $22.5 \%$. Since 2010 this year has almost doubled. The share of renewable sources within this share grew with one percentage point to $10.4 \%$.

The total amount of applied renewable energy grew from 10.0 to $11.5 \mathrm{PJ}$. Slightly more than half of the amount of energy applied from sources without $\mathrm{CO}_{2}$ emission was heat, the rest was electricity. Half of the heat coming from sources without $\mathrm{CO}_{2}$ emissions is produced by greenhouse growers themselves, the rest is purchased from third parties outside the sector. Geothermal heat is the most important source. Electricity is mostly purchased.

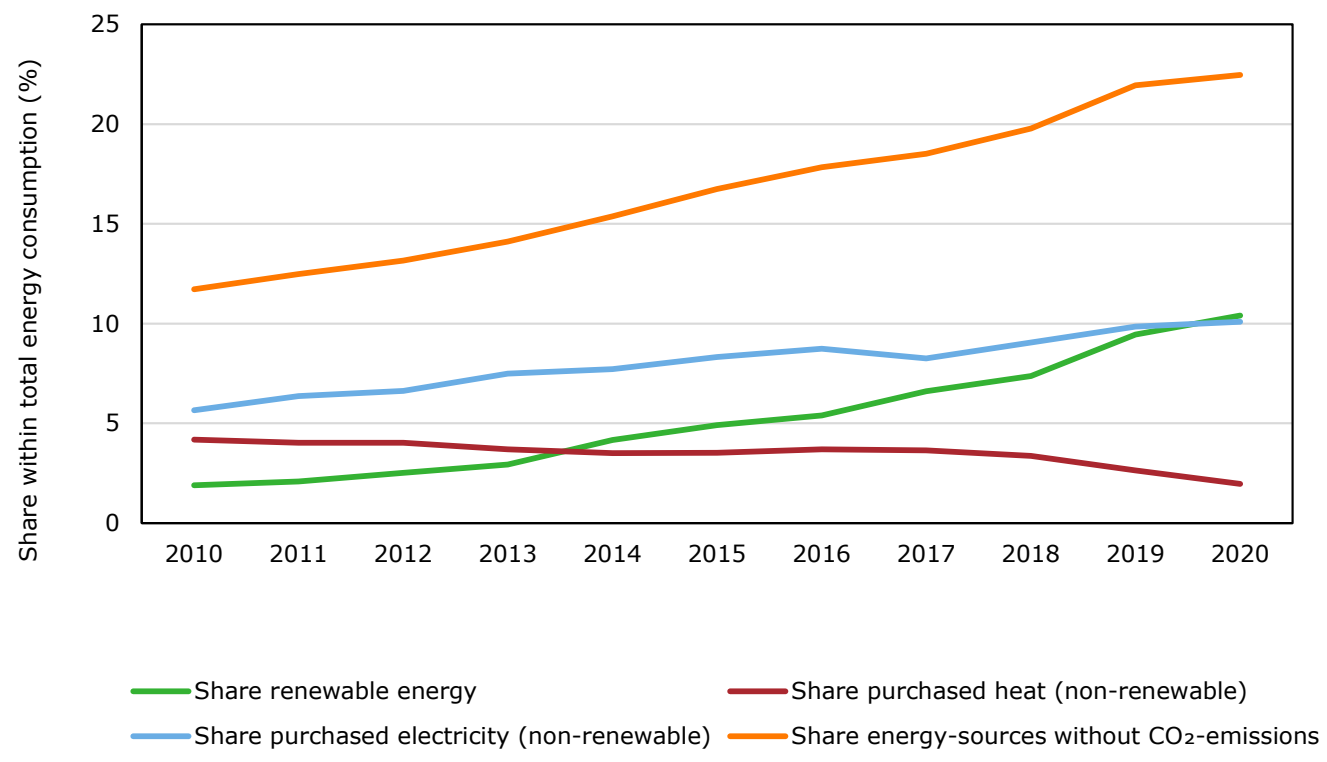

Figure S.2E Development of the share of energy-sources without $\mathrm{CO}_{2}$-emissions 2010-2020 v) v) Results for 2020 are provisional.

Deployment of natural gas CHP slightly shifted

Production of electricity using natural gas fired CHP (10.3 billion kWh) was slightly lower compared to $2019(-1 \%)$. There was however a shift from application of produced electricity to sale, partly caused by effects of corona measures and the average favourable sparkspread; the price-difference between input (natural gas) and output (electricity). By deploying $\mathrm{CHP}$ the total $\mathrm{CO}_{2}$ emissions of greenhouse horticulture were 2.8 Mtonne higher at sector level, but at a national level 4.4 Mtonne of $\mathrm{CO}_{2}$ emissions were prevented. This means a national reduction by use of CHP in greenhouse horticulture of 1.6 Mtonne. 


\section{S.3 Method Energy Monitor}

The Energy monitor for Dutch greenhouse horticulture annually quantifies the energy indicators $\mathrm{CO}_{2}$ emission, energy efficiency and the proportion of sustainable energy in greenhouse horticulture. To do this, the energy balance and physical production are surveyed and analysed together with the indicators and interpreted in the context of the corresponding developments. A method has been developed for these activities in which sector experts combine a range of information sources. The method is laid down in a protocol that is published in parallel with the Energy Monitor. 


\section{$1 \quad$ Inleiding}

\subsection{Energiemonitor van de Nederlandse glastuinbouw biedt inzicht}

De energietransitie van de glastuinbouw die moet leiden tot reductie van de $\mathrm{CO}_{2}$-emissie is complex en is voor de sector en de overheid een grote uitdaging. Hiervoor zijn inzichten nodig. De Energiemonitor van de Nederlandse glastuinbouw biedt een deel van deze inzichten. De ontwikkeling van de $\mathrm{CO}_{2}$-emissie wordt gekwantificeerd en van achtergronden voorzien. Uitkomsten worden geduid kijkend naar de beleidscontext en de praktijk van de Nederlandse glastuinbouw. Dit wordt gedaan voor indicatoren van de $\mathrm{CO}_{2}$-emissie, energie-efficiëntie, het aandeel duurzame energie en het aandeel van de energievoorziening zonder $\mathrm{CO}_{2}$-emissie.

Deze rapportage bevat de definitieve resultaten tot en met 2019 en de voorlopige resultaten van 2020 op basis van de medio 2021 beschikbare informatie. Hiernaast bevat de Energiemonitor van diverse indicatoren reeksen over een langjarige periode die inzicht geven in de ontwikkelingen.

De ontwikkeling van de $\mathrm{CO}_{2}$-emissie en de achterliggende factoren van invloed hierop komen aan bod in hoofdstuk 2. In hoofdstuk 3 is het gebruik van duurzame energie omschreven. Wkk, inkoop van warmte van partijen buiten de glastuinbouw en de elektriciteitsbalans van de glastuinbouw worden behandeld in hoofdstuk 4 . In hoofdstuk 5 komt de energievoorziening zonder $\mathrm{CO}_{2}$-emissie aan bod. Hierin wordt inzicht gegeven in het deel van de energietransitie van de glastuinbouwsector, waarbij de sector zich beweegt van een hoofdzakelijk fossiele energievoorziening naar een energievoorziening zonder $\mathrm{CO}_{2}$-emissie. Hierbij komen ook de belangrijkste ontwikkelingen van de gehele conventsperiode 2010-2020 aan bod. In hoofdstuk 6 volgen de conclusies.

De definities van de indicatoren, de werkwijze en de gebruikte bronnen voor de monitor zijn vastgelegd in het Protocol Energiemonitor Glastuinbouw (Smit en Van der Velden, 2021) en zijn in bijlage 1 samengevat. In het protocol staan zowel de conceptuele methodiek en de praktische werkwijze beschreven. De werkwijze kan in de loop der jaren wijzigen, onder andere door beschikbaarheid van databronnen en veranderingen van omrekeningsfactoren. Hierdoor wordt er jaarlijks naast de Energiemonitor glastuinbouw een update van het Protocol gepubliceerd.

\subsection{Meerjarenafspraak Energietransitie Glastuinbouw en programma Kas als Energiebron}

\section{Meerjarenafspraak Energietransitie Glastuinbouw}

De Nederlandse glastuinbouw en de Nederlandse overheid hebben in 2014 de Meerjarenafspraak Energietransitie Glastuinbouw 2014-2020 gemaakt. Deze afspraak geldt in combinatie met het Convenant $\mathrm{CO}_{2}$-emissieruimte binnen het $\mathrm{CO}_{2}$-sectorsysteem glastuinbouw. In beide convenanten staat de $\mathrm{CO}_{2}$-emissie centraal. Als onderdeel van de Nederlandse taakstelling voor het Europese doel om in $202020 \%$ minder $\mathrm{CO}_{2}$ uit te stoten in vergelijking met 1990 was het $\mathrm{CO}_{2}$-emissiedoel voor de Nederlandse glastuinbouw bepaald op 6,2 Mton in 2020. Na de technische correctie voor mutaties van het areaal en de verkoop van elektriciteit is in 2017 het doel aangepast naar 4,6 Mton. In de periode na deze correctie is duidelijk geworden dat een nieuwe technische correctie relevant is (Van der Velden en Smit, 2020)(Kamerbrief, 2021). Hierover is echter door de convenantspartijen nog geen besluit genomen. Hierdoor kan deze monitor geen antwoord geven op de vraag of de glastuinbouw het doel voor 2020 gerealiseerd heeft. 
Voorgaande convenanten

In eerdere convenanten waren ook doelen opgenomen over de energie-efficiëntie, het aandeel duurzame energie, de $\mathrm{CO}_{2}$-emissie van de teelt en de reductie van de $\mathrm{CO}_{2}$-emissie door wkk. In de Meerjarenafspraak van 2014 werden deze doelen weliswaar verlaten, maar het blijven elementen die van invloed zijn op de $\mathrm{CO}_{2}$-emissie. Het blijft daarom belangrijk om ook de ontwikkeling van deze indicatoren in beeld te brengen.

\section{Programma Kas als Energiebron}

Om het doel van de Meerjarenafspraak te bereiken, werken de glastuinbouw en de rijksoverheid samen in het programma Kas als Energiebron (KaE). Dit programma stimuleert met kennisontwikkeling, kennisuitwisseling en subsidies de energiebesparing en de inzet van duurzame energie. Voor 2050 heeft KaE de ambitie dat de glastuinbouw een volledig duurzame en economisch rendabele energievoorziening zonder $\mathrm{CO}_{2}$-emissie heeft. De glastuinbouw heeft hiernaast zelf de ambitie uitgesproken om al in 2040 geen $\mathrm{CO}_{2}$ meer uit te stoten en deze ambitie is ook een element van het Klimaatakkoord.

\section{$\mathrm{CO}_{2}$-emissie}

De $\mathrm{CO}_{2}$-emissie in de Meerjarenafspraak heeft betrekking op de absolute uitstoot van $\mathrm{CO}_{2}$. Deze wordt bepaald volgens de IPCC-methode (Intergovernmental Panel on Climate Change) en heeft betrekking op het fossiele brandstofverbruik op locatie. In- en verkoop van energie (elektriciteit en warmte) door de glastuinbouw tellen niet mee. Ook de uitstoot van andere broeikasgassen valt buiten de Meerjarenafspraak en deze monitor.

\section{$\mathrm{CO}_{2}$-emissieruimte en $\mathrm{CO}_{2}$-sectorsysteem}

Naast de Meerjarenafspraak bestaat er voor de glastuinbouw het $\mathrm{CO}_{2}$-sectorsysteem (Convenant, 2011) In de jaren dat de $\mathrm{CO}_{2}$-emissie van de gehele glastuinbouwsector boven de emissieruimte komt, wordt door de glastuinbouwbedrijven een heffing aan de overheid betaald. Deze kosten worden door de sector opgebracht middels het $\mathrm{CO}_{2}$-sectorsysteem. In dit systeem worden de kosten doorberekend aan de individuele bedrijven op basis van hun aardgasverbruik. Het $\mathrm{CO}_{2}$-sectorsysteem borgt hiermee het $\mathrm{CO}_{2}$-doel van de glastuinbouw.

\subsection{Glastuinbouw, energie en $\mathrm{CO}_{2}$-emissie continu in ontwikkeling}

Ontwikkeling $\mathrm{CO}_{2}$-emissie

De jaarlijkse $\mathrm{CO}_{2}$-emissie van de glastuinbouw wordt in de praktijk beïnvloed door 7 factoren (Van der Velden en Smit, 2017): de buitentemperatuur, het areaal kassen, verkoop van elektriciteit, gebruik van duurzame energie, inkoop van warmte, inkoop van elektriciteit en de energiegebruik per $\mathrm{m}^{2}$. Achter het energiegebruik per $\mathrm{m}^{2}$ zitten processen verbonden aan de teelt, namelijk intensivering, extensivering en energiebesparing.

\section{Intensivering en extensivering}

De energievraag van de glastuinbouw verandert door intensivering en extensivering. Het gematigde klimaat in Nederland met relatief koele zomers en zachte winters is gunstig voor de teelt van glastuinbouwproducten. De Nederlandse glastuinbouw kenmerkt zich door een relatief hoge fysieke productie en waarde, maar ook door hoge kosten per $\mathrm{m}^{2}$ kas. Vanuit marktvraag en door internationale concurrentie is in de Nederlandse glastuinbouw een doorlopend proces van intensivering gaande om de hoge productie en waarde van de producten in stand te houden en uit te bouwen. Innovatie van kassen, teeltsystemen, kennis en technologische hulpmiddelen zijn vooral gericht op verdere optimalisatie van de productie. Hiermee richt de sector zich op de wensen van de internationale markt. Dit leidt onder andere tot meer gewassen met een grotere energiebehoefte, maar ook tot toenemende productie in de winterperiode met groeilicht. Intensivering is hiermee een economisch gedreven proces dat ook leidt tot een toename van de energiebehoefte per $\mathrm{m}^{2}$ kas. Naast intensivering vinden er ontwikkelingen plaats waardoor er juist minder energie-intensief geteeld wordt, bijvoorbeeld door een verminderde vraag naar energie-intensievere producten, buitenlandse 
concurrentie of een sterkere vraag naar energie-extensievere gewassen. In deze gevallen daalt het gemiddelde energiegebruik per $\mathrm{m}^{2}$ kas.

\section{Energiebesparing}

Naast extensivering kan de energievraag per $\mathrm{m}^{2}$ kas ook dalen door energiebesparing. Door bijvoorbeeld de inzet van nieuwe kassen, (extra) energieschermen, efficiëntere lampen en energiezuinige teeltstrategieën zoals Het Nieuwe Telen (HNT). HNT is een innovatieve energiezuinige teeltstrategie voor regeling van het kasklimaat waarbij gebruik wordt gemaakt van natuur- en plantkundige kennis om de teelt optimaal te sturen voor wat betreft temperatuur, vocht, $\mathrm{CO}_{2}$-niveau, licht en het gebruik van schermen. Ook energiezuinige teeltstrategieën zijn doorlopend in ontwikkeling.

\section{Energievoorzieningen}

Naast de energievraag is de wijze waarop in deze vraag wordt voorzien van grote invloed op de ontwikkeling van de $\mathrm{CO}_{2}$-emissie van de glastuinbouw. Warmte uit aardgasgestookte ketels is al lange tijd niet meer de belangrijkste energievoorziening. Vandaag de dag wordt door de tuinders een mix ingezet van aardgas-wkk, ketels, duurzame energiebronnen en wordt er warmte en elektriciteit gekocht van partijen buiten de sector. Ook wordt er elektriciteit en in geringe mate warmte verkocht. Door het gebruik van duurzame energie en de inkoop van warmte en elektriciteit bestaat een deel van energievoorziening uit bronnen zonder fossiel brandstofverbruik door de glastuinbouw. Voorbeelden van duurzame energiebronnen in de glastuinbouw zijn aardwarmte, zonne-energie en biobrandstof. Daarnaast brengt de inkoop van warmte en elektriciteit van partijen van buiten de glastuinbouwsector geen $\mathrm{CO}_{2}$-emissie voor de glastuinbouwsector met zich mee.

\section{Areaal kassen}

De omvang en de kenmerken van de verzameling bedrijven met glastuinbouw in Nederland zijn van invloed op de $\mathrm{CO}_{2}$-emissie. De ontwikkeling van het totaal areaal glastuinbouw is primair afhankelijk van de vraag en productie van Nederlandse glastuinbouwproducten en de omstandigheden waarbij het aanbod wordt geproduceerd. Dit resulteert in nieuwbouw, sloop en bestemmingswijziging van kassen. Bovendien spelen hiernaast aanpassingen in de Landbouwtelling van het CBS een rol (bijlage 6).

\section{Buitentemperatuur}

De $\mathrm{CO}_{2}$-emissie van de glastuinbouw hangt voor een groot deel samen met het verwarmen van kassen. Hierdoor is de buitentemperatuur van invloed op de $\mathrm{CO}_{2}$-emissie. 


\section{Energie-indicatoren glastuinbouw}

\subsection{Totale $\mathrm{CO}_{2}$-emissie en $\mathrm{CO}_{2}$-emissie teelt per $\mathrm{m}^{2}$ gestegen}

Totale $\mathrm{CO}_{2}$-emissie gestegen

In 2020 is de $\mathrm{CO}_{2}$-emissie op sectorniveau, evenals in 2019, met 0,2 Mton toegenomen en uitgekomen op 6,1 Mton. De $\mathrm{CO}_{2}$-emissie lag in 2020 daarmee 0,1 Mton onder het oorspronkelijke doel in de Meerjarenafspraak van 6,2 Mton voor 2020. In vergelijking met het $\mathrm{CO}_{2}$-doel voor 2020 na technische correctie (4,6 Mton) lag de $\mathrm{CO}_{2}$-emissie in 2020 1,5 Mton boven het doel. De stijging in 2019 en 2020 ging vooraf door een sterke daling in de periode 2010 t/m 2014 en stabilisatie op een niveau van 5,7 Mton in periode 2015 t/m 2018 (figuur 2.1).

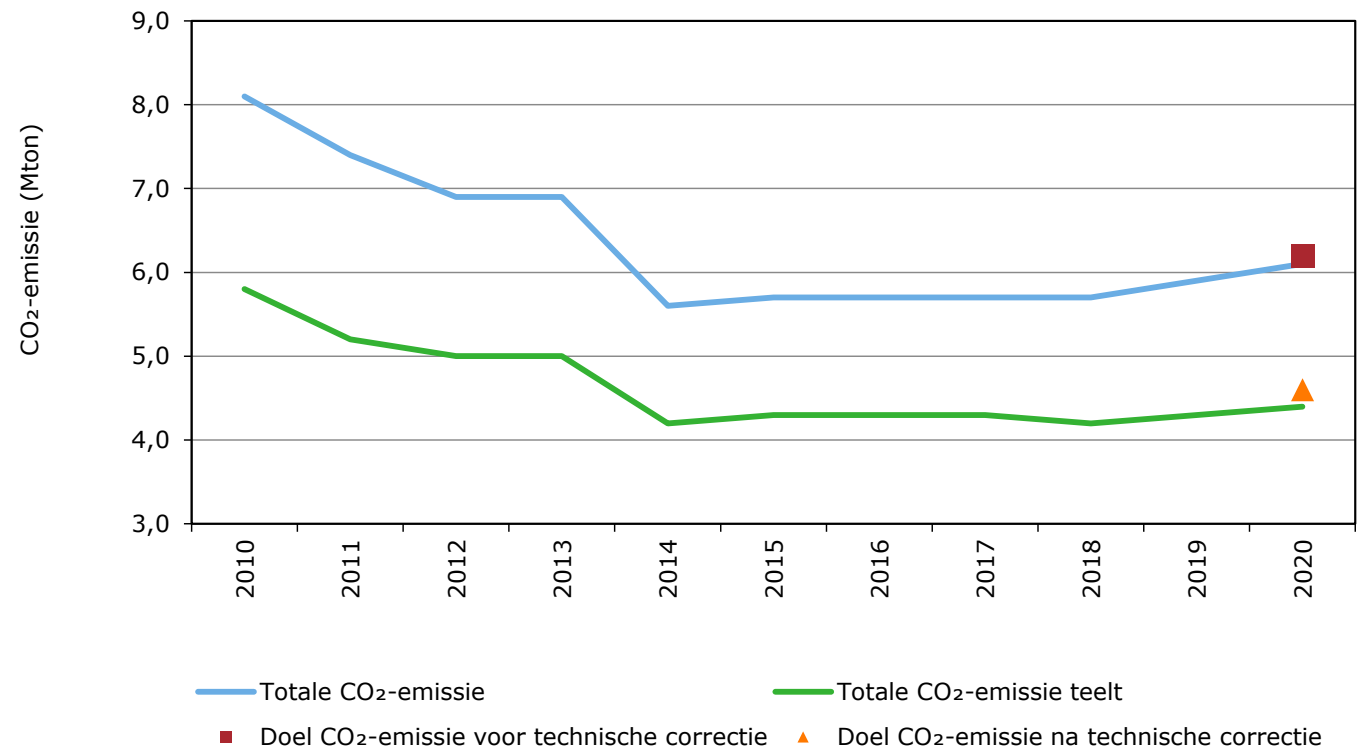

Figuur 2.1 $\mathrm{CO}_{2}$-emissie per jaar, $\mathrm{CO}_{2}$-emissie teelt zonder temperatuurcorrectie van de Nederlandse glastuinbouw en de doelen voor $2020 \mathrm{v}$ )

v) Cijfers 2020 voorlopig.

Interne en externe factoren beïnvloeden de $\mathrm{CO}_{2}$-emissie

De factoren van invloed op de $\mathrm{CO}_{2}$-emissie kunnen worden ingedeeld naar externe en interne factoren. De ontwikkeling van het areaal is vooral afhankelijk van de vraag naar glastuinbouwproducten en de verkoop elektriciteit is vooral afhankelijk van de energiemarkt. Beide worden beïnvloed door internationale economische ontwikkelingen. Glastuinbouwbedrijven hebben hierop weinig invloed. De ontwikkeling van de invloedsfactoren areaal en verkoop elektriciteit worden daardoor geschaard onder externe factoren. De invloedsfactoren duurzame energie, inkoop warmte, inkoop elektriciteit en energiegebruik per $\mathrm{m}^{2}$ zitten meer binnen de invloedsfeer van de glastuinbouw en worden hierom geschaard onder de interne factoren.

Areaal glastuinbouw toegenomen

In de Meerjarenafspraak Energietransitie Glastuinbouw 2014-2020 en in het Protocol van de Energiemonitor van de Nederlandse glastuinbouw is de sector glastuinbouw gedefinieerd als het areaal glastuinbouw in de Landbouwtelling (LBT) van het Centraal Bureau voor de Statistiek (CBS). Na 2019 
steeg ook in 2020 het areaal in de LBT. In 2020 was de stijging met $4 \%$ half zo groot in vergelijking met 2019. Deze stijging komt voort uit het saldo van nieuwbouw, sloop en bestemmingswijziging van kassen, maar ook door aanpassingen in de LBT. Mede omdat in de Energiemonitor geaggregeerd wordt met het areaal uit de LBT ligt hierdoor het aardgasverbruik en de $\mathrm{CO}_{2}$-emissie op sectorniveau in 2019 en 2020 op een hoger niveau dan in eerdere jaren (bijlage 6).

Temperatuurcorrectie na relatief warm jaar

De $\mathrm{CO}_{2}$-emissie wordt volgens de afspraken in het convenant niet gecorrigeerd voor verschillen in de buitentemperatuur tussen jaren. Het jaar 2020 was relatief warm. De toename van de $\mathrm{CO}_{2}$-emissie na temperatuurcorrectie in 2020 ten opzichte van 2019 bedraagt 0,3 Mton. Dit is 0,1 Mton meer dan de toename zonder temperatuurcorrectie.

\section{$\mathrm{CO}_{2}$-emissie teelt per $\mathrm{m}^{2}$ na temperatuurcorrectie in 2020 licht gestegen}

De $\mathrm{CO}_{2}$-emissie van de teelt per $\mathrm{m}^{2}$ na temperatuurcorrectie steeg in 2020 met 0,3 naar 45,7 kg. Deze stijging $(+0,7 \%)$ is minder dan de stijging van de totale $\mathrm{CO}_{2}$-emissie zonder temperatuurcorrectie $(+3,3 \%)$. Dit komt doordat de indicator $\mathrm{CO}_{2}$-emissie van de teelt per $\mathrm{m}^{2}$ na temperatuurcorrectie geen invloed ondervindt van de buitentemperatuur, het areaal, en de elektriciteitsverkoop. De laatste twee factoren hadden bij de mutatie van de totale $\mathrm{CO}_{2}$-emissie in 2020 juist de grootste invloed. Hieruit blijkt dat de stijging van de totale $\mathrm{CO}_{2}$-emissie in 2020 vooral voortkwam uit externe factoren. De indicator $\mathrm{CO}_{2}$-emissie van de teelt per $\mathrm{m}^{2}$ na temperatuurcorrectie geeft meer inzicht in de emissiereductie door inspanningen van de glastuinbouw zelf.

De $\mathrm{CO}_{2}$-emissie van de teelt per $\mathrm{m}^{2}$ na temperatuurcorrectie (figuur 2.2) daalde in de periode 2010 t/m $2014(-5,9 \mathrm{~kg})$, in de periode $2015 \mathrm{t} / \mathrm{m} 2018$ was deze min of meer stabiel $(-0,1 \mathrm{~kg})$ gevolgd door een daling $(-2,3 \mathrm{~kg})$ in de periode 2019 t/m 2020. In de jaren 2019 en 2020 werd de ontwikkeling van de $\mathrm{CO}_{2}$-emissie per $\mathrm{m}^{2}$ na temperatuurcorrectie sterker gedempt door de groei van het gebruik van energiebronnen zonder $\mathrm{CO}_{2}$-emissie voor de glastuinbouw (duurzame energie, inkoop elektriciteit en inkoop warmte van derden) dan in de periode hiervoor.

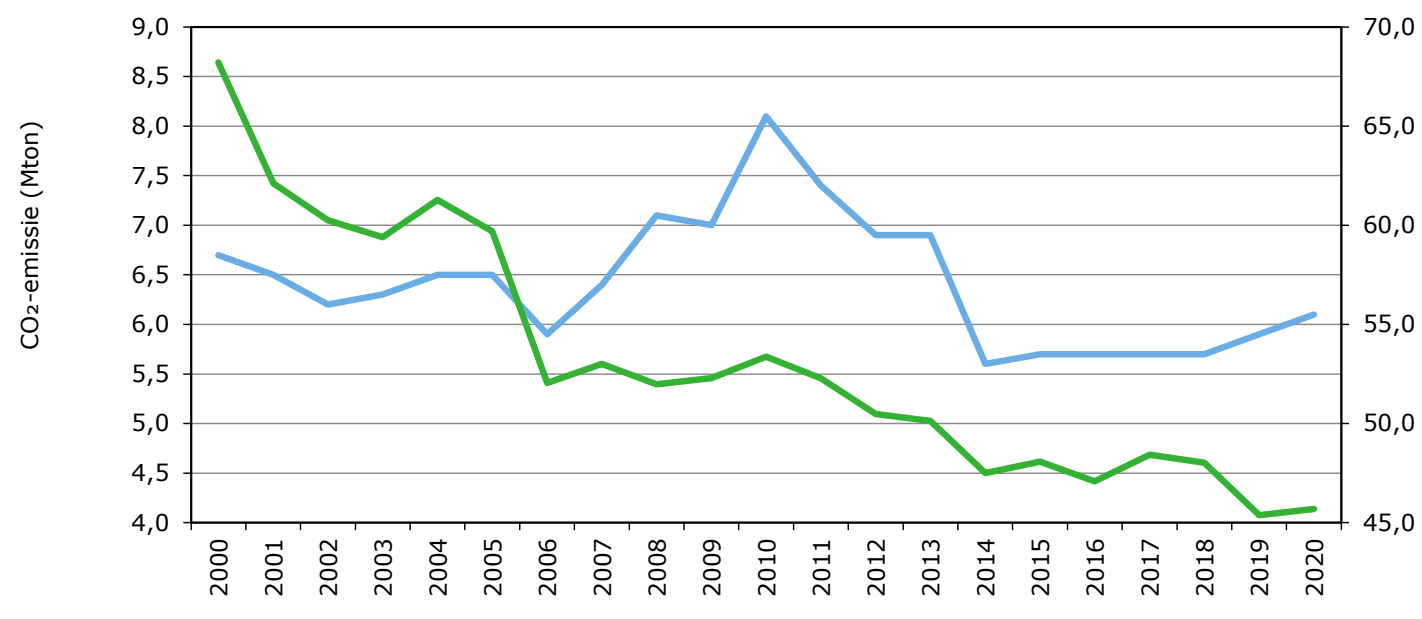

Totale $\mathrm{CO}_{2}$-emissie (Mton) $-\mathrm{CO}_{2}$-emissie teelt na temperatuurcorrectie per $\mathrm{m}^{2}(\mathrm{~kg})$

Figuur 2.2 $\mathrm{CO}_{2}$-emissie totaal en $\mathrm{CO}_{2}$-emissie teelt per $\mathrm{m}^{2}$ na temperatuurcorrectie $v$ ) v) Cijfers 2020 voorlopig.

$\mathrm{CO}_{2}$-emissiereductie glastuinbouw op niveau landelijke ontwikkeling

Voor Nederland als geheel kwam de $\mathrm{CO}_{2}$-emissie (exclusief overige broeikasgassen) in 2020 uit op 138,1 Mton (CBS, bijlage 2). Dit is $90 \%$ van de $\mathrm{CO}_{2}$-emissie in 1990 ; een reductie van $10 \%$. In de glastuinbouw lag de $\mathrm{CO}_{2}$-emissie in $202011 \%$ onder het niveau van 1990 . Het reduceren van de $\mathrm{CO}_{2}-$ 
emissie in de glastuinbouw lag in 2020 dus globaal op hetzelfde niveau als landelijk. Dit terwijl de sector op nationaal niveau met aardgas wkk een substantiële hoeveelheid elektriciteit met aardgas produceert en verkoopt. Ook was er in 2020 een sterke daling de landelijke $\mathrm{CO}_{2}$-emissie mede door corona-omstandigheden (CBS).

Wordt alleen gekeken naar de $\mathrm{CO}_{2}$-emissie van de teelt zonder temperatuurcorrectie, dan lag deze in $202035 \%$ onder het niveau van 1990 en daalde dus sterker dan landelijk.

Warmtekrachtkoppeling van grote invloed op de $\mathrm{CO}_{2}$-emissie

De glastuinbouw produceerde in 2020 circa 10,3 miljard kWh elektriciteit met aardgas-wkk (hoofdstuk 4). De productie was in 2020 bijna gelijk aan die van het recordjaar 2019 (-1\%). Door deze productie werd in 2020 op nationaal niveau op basis van het primair brandstofverbruik (paragraaf 2.3) 1,6 Mton $\mathrm{CO}_{2}$-emissie vermeden. Deze vermeden $\mathrm{CO}_{2}$-emissie kwam door het benutten van de warmte die geproduceerd wordt in combinatie met elektriciteitsproductie met wkk. Hierdoor was het brandstofverbruik in elektriciteitscentrales circa 2,4 miljard $\mathrm{m}^{3}$ aardgasequivalenten lager en lag het aardgasverbruik in de glastuinbouw circa 1,6 miljard $\mathrm{m}^{3}$ hoger. Dit laatste is het saldo van het extra aardgasverbruik in de wkk's $\left(2,9\right.$ miljard $\left.\mathrm{m}^{3}\right)$ minus het verminderde verbruik in verwarmingsketels $\left(1,3\right.$ miljard $\mathrm{m}^{3}$ ). Per saldo werd er op nationaal niveau circa 0,8 miljard $\mathrm{m}^{3}$ aardgasequivalenten aan primair brandstof bespaard met inzet van aardgas-wkk's in de glastuinbouw.

\subsection{Energie-efficiëntie verslechterd}

De energie-efficiëntie-index is in 2020 ten opzichte van 2019 met 2 procentpunten verslechterd naar $50 \%$ (figuur 2.3). De glastuinbouw gebruikte daarmee in 2020 circa de helft minder primair brandstof per eenheid product in vergelijking met 1990. De verslechtering in $2020 \mathrm{kwam}$ doordat het primair brandstofverbruik per $\mathrm{m}^{2}$ steeg en de fysieke productie per $\mathrm{m}^{2}$ daalde.

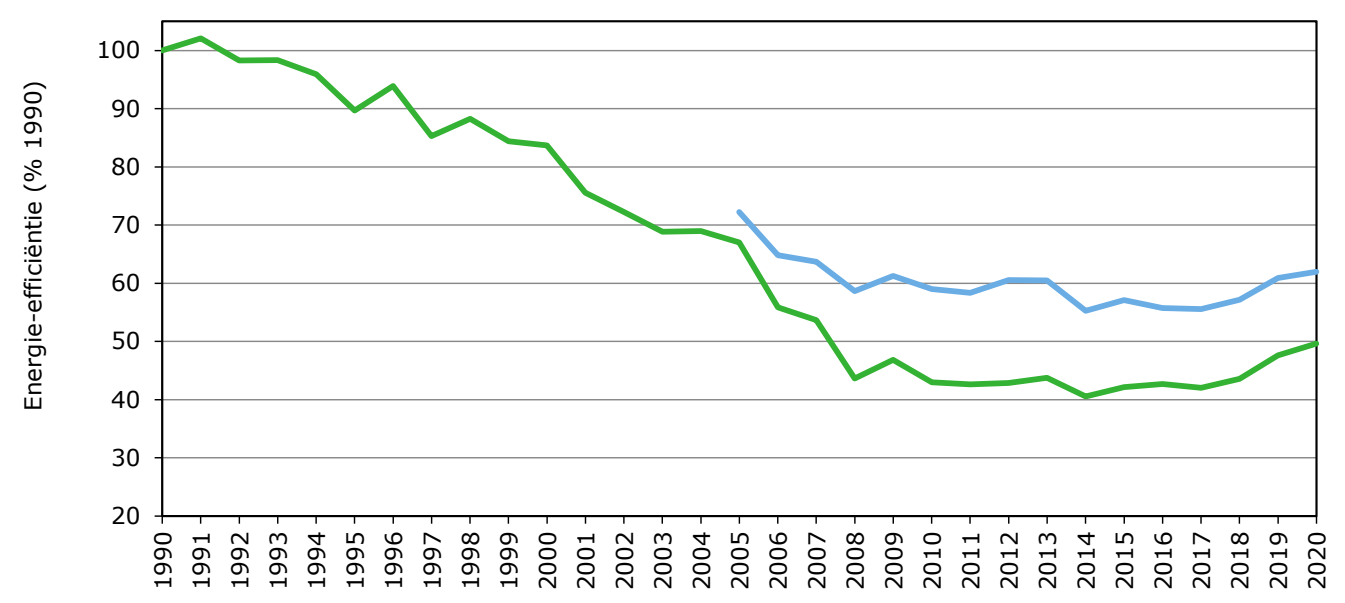

Werkelijke ontwikkeling _ _ Fictieve ontwikkeling (exclusief wkk glastuinbouw)

Figuur 2.3 Energie-efficiëntie van de productieglastuinbouw per jaar met en zonder wkk glastuinbouw $v$ )

v) Cijfers 2020 voorlopig.

Als de achterliggende jaren worden beschouwd, was de energie-efficiëntie in de periode $2010 \mathrm{t} / \mathrm{m}$ 2014 min of meer stabiel en verslechterde in de periode 2014-2020 (figuur 2.3). Naast het toegenomen areaal in de Landbouwtelling (LBT) komt deze ontwikkeling ook door het nastreven van een hogere waarde per eenheid product en door telen voor de marktvraag (winterproductie met belichting). Deze processen remmen de ontwikkeling van de fysieke productie (minder eenheden product) en doen het primair brandstofverbruik toenemen. 


\section{Primair brandstofverbruik gestegen}

Het primair brandstofverbruik per $\mathrm{m}^{2}$ in 2020 steeg met 0,5\% ten opzichte van 2019 (figuur 2.4). De toename van het gebruik van duurzame warmte (hoofdstuk 3 ) en de toename van de verkoop van elektriciteit (hoofdstuk 4) deden het primair brandstofverbruik dalen. De toename van de inkoop van elektriciteit en daling van de inkoop niet-duurzame warmte zorgden daarentegen voor een stijging. Over de gehele periode 2010-2020 nam het primair brandstofverbruik per $\mathrm{m}^{2}$ geleidelijk toe. In de eerste helft van deze periode was deze ontwikkeling wat minder sterk dan in de tweede helft. Dit kwam vooral door de daling van het energiegebruik per $\mathrm{m}^{2}$ die werd gevolgd door een stijging. Daarnaast hadden de verminderde hoeveelheid elektriciteit die werd verkocht in de eerste helft en de geleidelijke toename van inkoop elektriciteit over de gehele periode een negatieve invloed. De toename van duurzame energie had over de gehele periode een positieve invloed.

\section{Fysieke productie afgenomen}

De fysieke productie per $\mathrm{m}^{2}$ vertoont vanaf 1990 een stijgende trend, maar is sinds 2017 dalende. In 2020 daalde de fysieke productie met 3,7\%. Er zijn duidelijk verschillen tussen de jaren (figuur 2.4 en bijlage 2). Over de periode 1990-2017 nam de fysieke productie per $\mathrm{m}^{2}$ met circa de helft toe. Dat is gemiddeld 1,5\% per jaar. In de periode 1990-2008 was dit 2\% per jaar. Vanaf 2008 vlakte de groei af. In de periode 2008-2017 was de groei gemiddeld 1,0\% per jaar. Dit hangt samen met de vraag vanuit de afzetmarkt naar kwaliteitsproducten en de planning van de afzet van de productie, oftewel een verschuiving van kwantiteit naar kwaliteit afgestemd op de klantvraag. Na 2017 en vooral in 2019 en 2020 nam de fysieke productie af. Dit laatste kwam mede door aanpassingen in de LBT (paragraaf 2.1). Verder hebben in 2020 coronamaatregelen bij bepaalde productgroepen en segmenten een negatieve invloed gehad op de fysieke productie.

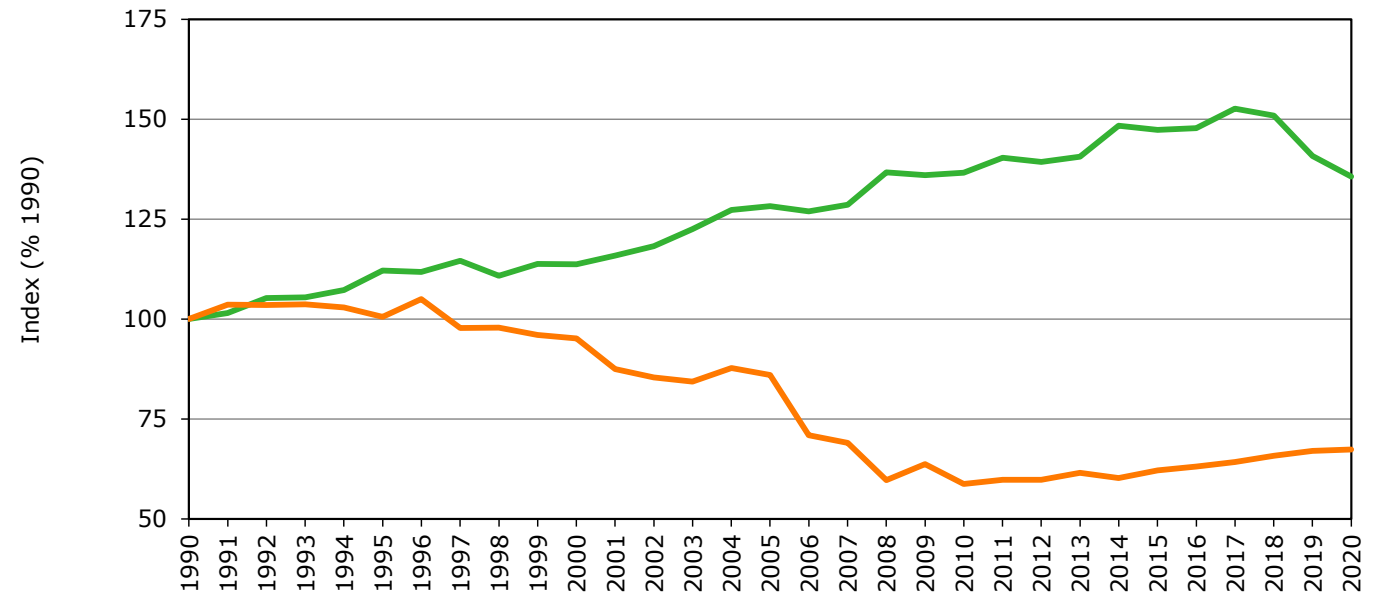

Index fysieke productie per $\mathrm{m}^{2} \quad$ Index primair brandstofverbruik per $\mathrm{m}^{2}$

Figuur 2.4 Fysieke productie en primair brandstofverbruik in de productieglastuinbouw per $m^{2}$ kas v) v) Cijfers 2020 voorlopig.

\section{Effect warmtekrachtkoppeling toegenomen}

Het gebruik van wkk heeft een positief effect op de energie-efficiëntie, omdat bij de productie van elektriciteit ook de vrijkomende warmte nuttig wordt ingezet. Dit in tegenstelling tot de productie in elektriciteitscentrales waar de vrijkomende warmte voor een groot deel niet wordt benut (hoofdstuk 4). In 2012 lag het effect van het gebruik van wkk op ongeveer 18 procentpunten in vergelijking met een situatie zonder wkk (figuur 2.3). In de periode 2012-2016 was dit effect teruggelopen tot 13 procentpunten. De vermindering hangt samen met de verminderde elektriciteitsproductie door wkk voor de verkoop in die periode door een ongunstige spark spread (het verschil tussen de prijs van de input (aardgas) en de output (elektriciteit). Na 2016 nam het effect van 
wkk op de energie-efficiëntie weer toe naar 14 procentpunten in 2020. De spark spread was gunstig en mede hierdoor nam de elektriciteitsverkoop na 2016 toe. Dit effect werd geremd door toename van de eigen consumptie van de elektriciteit geproduceerd met de wkk.

\subsection{Aandeel duurzame energie gegroeid}

Gebruik duurzame energie wederom toegenomen

Het gebruik van duurzame energie in het totaal energiegebruik is ook in 2020 gegroeid. Het aandeel groeide van 9,5 naar 10,4\% (figuur 2.5), doordat het gebruik van duurzame energie meer toenam dan het totaal energiegebruik steeg. Het absolute gebruik van duurzame energie nam toe van 10,0 naar 11,5 PJ. De groei nam af van 2,1 PJ in 2019 naar 1,0 PJ in 2020. Dit verschil hangt mede samen met het ongelijkmatige verloop in de beginfase van de energietransitie waarin de glastuinbouw zich bevindt; enkele projecten meer of minder kunnen nog een relatief groot verschil maken.

Zowel het absolute gebruik van duurzame energie als het aandeel duurzaam in het totaal energiegebruik vertonen vanaf 2000 groei. In de periode 2010-2020 groeide het aandeel met ruim 8 procentpunten en het absolute gebruik van duurzame energie vervijfvoudigde bijna.

Duurzame energie die door de glastuinbouw werd toegepast, bestond voor circa $93 \%$ uit warmte en voor $7 \%$ uit elektriciteit. De toegepaste hoeveelheid duurzame energie werd voor circa $58 \%$ door de sector zelf geproduceerd en voor circa $42 \%$ ingekocht bij partijen buiten de glastuinbouwsector. Van de toegepaste duurzame warmte kwam $61 \%$ uit productie door de sector zelf. Duurzame elektriciteit werd voor $94 \%$ ingekocht. De hoeveelheid duurzame energie die door de glastuinbouw aan afnemers buiten de sector werd verkocht was beperkt van omvang.

Groei aandeel duurzame energie glastuinbouw volgt landelijke ontwikkeling

Voor Nederland als geheel bedroeg het aandeel duurzame energie in 2019 8,7 en in $202011,1 \%$ (CBS). Het aandeel duurzame energie in de glastuinbouw lag in 2020 met 10,4\% iets onder het aandeel op nationaal niveau. De ontwikkeling van het aandeel in de glastuinbouw volgt hiermee de ontwikkeling van het landelijk aandeel. Hierbij moet vermeld worden dat het landelijk aandeel het aandeel in productie betreft en dat van de glastuinbouw het aandeel in de consumptie betreft. De groei van het landelijk aandeel werd in 2020 naast groei van de duurzame energieproductie ook beïnvloed door lagere consumptie door corona-omstandigheden.

In 2010 bedroeg het aandeel in de glastuinbouw nog maar de helft van het aandeel in geheel Nederland. Het aandeel in de glastuinbouw groeide in de periode 2010-2020 sterker dan landelijk.

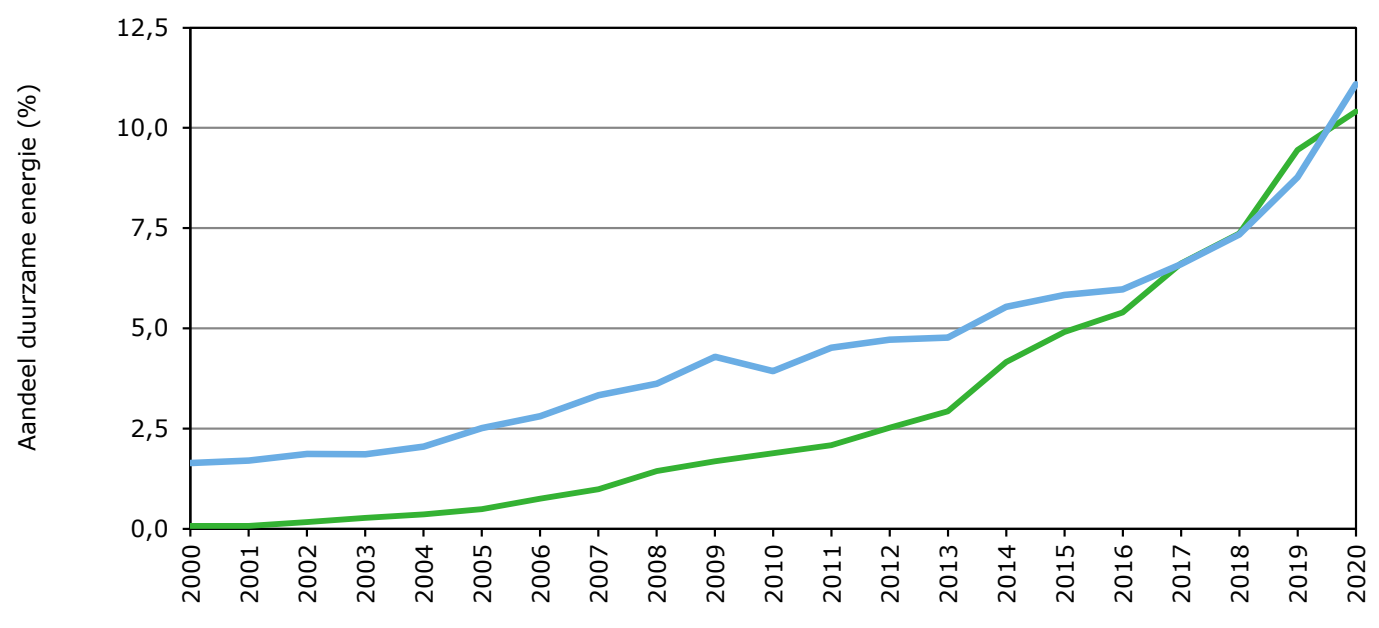

Aandeel duurzame energie glastuinbouw _ Aandeel duurzame energie Nederland

Figuur 2.5 Aandeel duurzame energie per jaar in de glastuinbouw en landelijk $v$ )

v) Cijfer 2020 voorlopig. 
Het gebruik van duurzame energie had in 2020 een positief effect op de $\mathrm{CO}_{2}$-emissie op sectorniveau van bijna 0,6 Mton. Op de energie-efficiëntie was het effect ruim 5 procentpunten (paragraaf 3.4).

\subsection{Kwantitatieve analyse ontwikkeling $\mathrm{CO}_{2}$-emissie}

Drie perioden met eigen kenmerkende ontwikkelingen

In de jaren 2010 t/m 2020 kunnen drie perioden worden onderscheiden met verschillen in ontwikkeling van de $\mathrm{CO}_{2}$-emissie. In de periode $2010 \mathrm{t} / \mathrm{m} 2014$ daalde de $\mathrm{CO}_{2}$-emissie van de glastuinbouw met 2,4 Mton en in de periode 2015 t/m 2018 was er stabilisatie met een toename van minder dan 0,1 Mton (figuur 2.1). Zowel in 2019 als in 2020 steeg de $\mathrm{CO}_{2}$-emissie. Over de periode 2019 t/m 2020 nam de $\mathrm{CO}_{2}$-emissie met 0,4 Mton toe. In deze paragraaf worden de achtergronden van de ontwikkelingen in deze perioden geanalyseerd.

\section{Buitentemperatuur is van invloed}

De jaren 2014, 2018, 2019 en 2020 waren relatief warm en 2010 was relatief koud. Als voor de buitentemperatuur gecorrigeerd wordt, bedroeg de daling van de $\mathrm{CO}_{2}$-emissie in de periode $2010 \mathrm{t} / \mathrm{m}$ 2014 1,9 Mton in plaats van 2,5 Mton. In de periode 2015 t/m 2018 was er na temperatuurcorrectie een lichte daling van de $\mathrm{CO}_{2}$-emissie van 0,1 Mton, waar dit voor correctie een lichte stijging was 0,1 Mton was. In de periode $2019 \mathrm{t} / \mathrm{m} 2020$ steeg de $\mathrm{CO}_{2}$-emissie na temperatuurcorrectie ten opzichte van 2018 met 0,5 Mton, waar dit zonder correctie 0,4 Mton was. De $\mathrm{CO}_{2}$-emissie na temperatuurcorrectie is het vertrekpunt voor de analyse van de overige invloedsfactoren (tabel 2.1).

Tabel 2.1 Ontwikkeling van de invloedsfactoren a) op de $\mathrm{CO}_{2}$-emissie van de glastuinbouw in de periode 2010-2020 v)

\begin{tabular}{llrrrrr} 
Invloedsfactor & eenheid & 2010 & 2014 & 2018 & 2019 & $2020 \mathrm{v})$ \\
Areaal & ha & 10.307 & 9.488 & 8.990 & 9.688 & 10.078 \\
\hline Verkoop elektriciteit & TWh & 8,2 & 5,2 & 5,4 & 5,8 & 6,1 \\
\hline Inzet duurzame energie & PJ & 2,4 & 4,0 & 6,7 & 10,0 & 11,5 \\
\hline Inkoop elektriciteit a) & TWh & 2,0 & 2,1 & 2,5 & 2,9 & 3,1 \\
\hline Inkoop warmte a) & PJ & 5,3 & 3,4 & 3,4 & 2,8 & 2,2 \\
\hline
\end{tabular}

a) Exclusief duurzaam (dat wordt meegenomen bij 'Inzet duurzame energie').

b) Exclusief energiegebruik per $\mathrm{m}^{2}$ (intensivering, extensivering en besparing).

v) Cijfers 2020 voorlopig.

Analyse van invloedsfactoren $\mathrm{CO}_{2}$-emissie na temperatuurcorrectie

$\mathrm{Na}$ de invloed van de buitentemperatuur wordt de ontwikkeling van de $\mathrm{CO}_{2}$-emissie bepaald door de zes invloedsfactoren (zie ook paragraaf 1.3). Dit zijn: (1) het areaal glastuinbouw, (2) de verkoop van elektriciteit, (3) de inzet van duurzame energie, (4) de inkoop van warmte, (5) de inkoop van elektriciteit en (6) het energiegebruik per $\mathrm{m}^{2}$. Van de eerste vijf factoren is voor analyse kwantitatieve informatie beschikbaar. De laatste factor, het energiegebruik per $\mathrm{m}^{2}$, wordt bepaald door intensivering, extensivering en energiebesparing (zie ook paragraaf 1.3). Door intensivering neemt het energiegebruik toe en door extensivering en energiebesparing neemt het energiegebruik af. Van deze drie achterliggende, afzonderlijke factoren is weinig kwantitatieve informatie beschikbaar. Dit komt doordat deze processen gelijktijdig achter de energiemeters plaatsvinden. Het effect wordt daarom als saldo gekwantificeerd. ${ }^{1}$

Voor verdere toelichting over de kwantificering van de effecten wordt verwezen naar de Energiemonitor Glastuinbouw 2017 (Van der Velden en Smit, 2017b) en voor de nadere analyse van

1 In 2017 is door Wageningen Economic Research de studie Effect intensivering, extensivering en energiebesparing op CO ${ }_{2}-$ emissie Nederlandse glastuinbouw uitgevoerd. In deze studie is een methodiek ontwikkeld voor de kwantificering van het effect van intensivering, extensivering en energiebesparing, zijn de effecten over de periode 2010-2015 gekwantificeerd en zijn de achtergronden van de ontwikkelingen geduid (Van der Velden en Smit, 2017). 
intensivering, extensivering en energiebesparing naar (Van der Velden en Smit, 2017). Hieronder volgen de invloeden over 3 kenmerkende perioden.

Tabel 2.2 Effect op de $\mathrm{CO}_{2}$-emissie door de invloedsfactoren in de afzonderlijke perioden 20102020 (Mton) v)

\begin{tabular}{lccc} 
Invloedsfactor & $2010 \mathrm{t} / \mathrm{m} 2014$ & $2015 \mathrm{t} / \mathrm{m} 2018$ & $2019 \mathrm{t} / \mathrm{m} 2020$ \\
Areaal & $-0,42$ & $-0,24$ & 0,51 \\
\hline Verkoop elektriciteit & $-0,86$ & 0,05 & $-0,21$ \\
\hline Inzet duurzame energie & $-0,09$ & $-0,21$ & $-0,15$ \\
\hline Inkoop elektriciteit a) & $-0,02$ & $-0,13$ & 0,07 \\
\hline Inkoop warmte a) & 0,11 & $-0,00$ & 0,41 \\
\hline Subtotaal & $-1,28$ & 0,39 & $\mathbf{0 , 0 6}$ \\
\hline Energiegebruik per $\mathrm{m}^{2}$ & $-0,58$ & $\mathbf{- 0 , 1 3}$ & $\mathbf{0 , 4 7}$ \\
\hline Totaal & $\mathbf{- 1 , 8 6}$ & & \\
\hline
\end{tabular}

v) Cijfers 2019 t/m 2020 voorlopig.

Periode 2010 t/m 2014; Daling van de $\mathrm{CO}_{2}$-emissie

De krimp van het areaal, de daling van de elektriciteitsverkoop (wkk), de toename van het gebruik van duurzame energie en de groei van de inkoop van elektriciteit deden de $\mathrm{CO}_{2}$-emissie in de periode 2010 t/m 2014 dalen (tabel 2.2). De afgenomen inkoop warmte had een stijgend effect. De effecten van de afname van de verkoop van elektriciteit en de krimp van het areaal hadden het grootste effect. Het gezamenlijk effect van deze eerste vijf invloedsfactoren bedroeg in de periode $2010 \mathrm{t} / \mathrm{m} 2014$ $-1,3 \mathrm{Mton} \mathrm{CO}_{2}$. Dit verklaart 53\% van de totale reductie van 1,9 Mton in deze periode. De resterende reductie van 0,6 Mton $\mathrm{CO}_{2}$ was het saldo-effect van intensivering, extensivering en energiebesparing; oftewel de mutatie van het energiegebruik per $\mathrm{m}^{2}$. De daling van het energiegebruik per $\mathrm{m}^{2}$ betekende dat het gezamenlijk effect van energiebesparing en extensivering in de periode $2010 \mathrm{t} / \mathrm{m} 2014$ groter was dan het effect van intensivering.

Periode 2015 t/m 2018; Lichte daling van de $\mathrm{CO}_{2}$-emissie

De krimp van het areaal in de LBT, de groei van de inzet van duurzame energie en de toegenomen inkoop van elektriciteit zorgden in de periode $2015 \mathrm{t} / \mathrm{m} 2018$ voor een daling van de $\mathrm{CO}_{2}$-emissie (tabel 2.2). Doordat de verkoop van elektriciteit toenam, steeg de $\mathrm{CO}_{2}$-emissie. Ook door de daling van de inkoop van warmte nam de $\mathrm{CO}_{2}$-emissie toe. De krimp van het areaal en de groei van de inzet van duurzame energie hadden de grootste invloed.

In de periode 2015 t/m 2018 bedroeg het gezamenlijk effect van deze 5 invloedsfactoren -0,5 Mton $\mathrm{CO}_{2}$. Het gezamenlijk effect van intensivering, extensivering en energiebesparing (mutatie van het energiegebruik per $\mathrm{m}^{2}$ ) was $0,4 \mathrm{Mton} \mathrm{CO}_{2}$. De toename van het energiegebruik per $\mathrm{m}^{2}$ dempte de daling van de $\mathrm{CO}_{2}$-emissie, dit in tegenstelling tot de periode $2010 \mathrm{t} / \mathrm{m} 2014$ toen deze de daling versterkte. De stijging van het energiegebruik per $\mathrm{m}^{2}$ betekende dat het effect van intensivering in de periode 2015 t/m 2018 groter was dan het gezamenlijk effect van energiebesparing en extensivering.

Stijging van de $\mathrm{CO}_{2}$-emissie in 2019 werd in 2020 voortgezet

In de periode 2019 t/m 2020 steeg de $\mathrm{CO}_{2}$-emissie zonder temperatuurcorrectie met 0,4 Mton en na temperatuurcorrectie met 0,5 Mton. De ontwikkelingen van de factoren die de $\mathrm{CO}_{2}$-emissie hebben beïnvloed in deze periode volgen hieronder.

- Areaal nam toe: Volgens de LBT van het CBS steeg het areaal glastuinbouw in 2019 met $8 \%$ (700 ha) en in 2020 met 4\% (390 ha). De verschillen in de mutaties per gewasgroep tussen 2018 en 2020 zijn dusdanig dat de groei van het areaal glastuinbouw grofweg evenredig verdeeld is over de sector. Door de toename in het areaal nam de $\mathrm{CO}_{2}$-emissie met 0,51 Mton toe.

- Verkoop elektriciteit steeg: De verkoop van elektriciteit nam in 2020 opnieuw toe. In 2020 was de stijging iets minder sterk dan in 2019 ( $+5 \%$ versus $+7 \%$ ). Door de groei van de verkoop van elektriciteit nam de $\mathrm{CO}_{2}$-emissie in met 0,19 Mton toe. 
- Inzet duurzame energie groeide: Het gebruik van duurzame energie is blijven groeien. In 2020 was de toename wel minder sterk dan in 2019 (+15\% versus $+37 \%)$. Door de groei van het gebruik van duurzame energie nam de $\mathrm{CO}_{2}$-emissie met 0,21 Mton af.

- Inkoop warmte daalde: De inkoop van warmte (exclusief duurzame warmte) is in 2020 opnieuw afgenomen. Deze daling komt hoofdzakelijk door de groei van de fractie duurzaam bij centrale restwarmteprojecten (wordt meegenomen bij duurzame energie), het toegenomen gebruik van wkk en energiebesparing. Door de daling bij inkoop warmte nam de $\mathrm{CO}_{2}$-emissie met 0,07 Mton toe.

- Inkoop elektriciteit steeg: $\mathrm{Na}$ een sterkere stijging van de inkoop elektriciteit in $2019(+12 \%)$ nam in 2020 de inkoop van elektriciteit minder sterk toe $(+1 \%)$. Door groei van de hoeveelheid ingekochte elektriciteit nam de $\mathrm{CO}_{2}$-emissie in met 0,15 Mton af.

- Energiegebruik per $\mathrm{m}^{2}$ : Het effect van energiegebruik per $\mathrm{m}^{2}$ is het saldo van de effecten van intensivering, extensivering en energiebesparing. Dit totaal effect nam in 2019 licht af en in 2020 toe. De intensivering en extensivering wordt mede beïnvloed door de areaalmutaties per gewas. In zowel 2019 als 2020 nam het warmtegebruik per $\mathrm{m}^{2}$ af en het gebruik van elektriciteit per $\mathrm{m}^{2}$ toe. Per saldo nam de $\mathrm{CO}_{2}$-emissie als gevolg van verandering van het energiegebruik per $\mathrm{m}^{2}$ toe met 0,06 Mton. Hieruit blijkt dat het gezamenlijk effect van extensivering en energiebesparing in de periode 2019 t/m 2020 kleiner geweest dan het effect van intensivering. De stijging van het energiegebruik per $\mathrm{m}^{2}$ was in de periode $2019 \mathrm{t} / \mathrm{m} 2020$ wel minder sterk dan in de periode 2015 $\mathrm{t} / \mathrm{m} 2018$.

Samengevat: De $\mathrm{CO}_{2}$-emissie is in de periode $2019 \mathrm{t} / \mathrm{m} 2020$ vooral gestegen door de toename van het areaal, toename van verkoop van elektriciteit en in mindere mate door daling van de inkoop van warmte van derden en de toename van het energiegebruik per $\mathrm{m}^{2}$. De stijging werd gedempt door de groei van de inzet van duurzame energie en de toename van inkoop elektriciteit.

\subsection{Energiekosten gedaald}

Wkk blijft dominante factor

Voor de gemiddelde energiekosten van de glastuinbouw op sectorniveau is het gebruik van aardgas in wkk's (gasmotoren) de dominante factor. Het gebruik van aardgas wkk gaat samen met de inkoop van aardgas en de productie van elektriciteit voor eigen gebruik en verkoop. In 2020 namen de wkk's circa $85 \%$ van het aardgasverbruik voor hun rekening. Meer dan de helft van de elektriciteitsconsumptie werd met wkk opgewekt. Hiernaast wordt meer dan de helft van de met wkk geproduceerde elektriciteit verkocht. De netto-energiekosten zijn het saldo van de kosten van de energie die wordt gekocht (inclusief inkoop $\mathrm{CO}_{2}$ ) en de opbrengsten van de energie die wordt verkocht.

Het areaal met wkk (circa 60\%) is vooral te vinden bij de grotere bedrijven. Hiernaast zijn er een groot aantal vooral kleinere bedrijven zonder wkk die vooral met een gasketel in hun warmtevraag voorzien.

Inkoop en verkoop beïnvloed door de inzet van wkk

De kosten voor de inkoop van energie bestaan uit de prijs voor de commodity's (eenheden; $\mathrm{m}^{3}$ aardgas, kWh elektriciteit, GJ warmte), de dienstenkosten (netwerk) en heffingen. De opbrengsten van de verkoop betreffen de commodity prijs. De dienstenkosten en heffingen komen bij verkoop voor rekening van de afnemer en niet voor de producent.

De door tuinders betaalde gemiddelde commodityprijs voor aardgas nam in de periode voor 2017 af, daarna toe en in 2019 en 2020 weer af. De gemiddelde commodityprijs voor de inkoop en verkoop van elektriciteit liet een overeenkomstige ontwikkeling zien. De laatste jaren was echter de stijging bij verkoop en inkoop elektriciteit groter dan de stijging bij inkoop aardgas. Hierdoor werd de spark spread gunstiger en verbeterde het exploitatieresultaat om met de aardgas-wkk elektriciteit te produceren voor de verkoop en voor eigen gebruik. De gebruiksduur van de wkk's nam hierdoor toe, in 2018 met circa 3\% en in 2019 met circa 4\%. In 2020 lag de gebruiksduur net boven de 4.000 uur. Het gebruik van de wkk's wordt begrensd vanuit de warmtevraag op de bedrijven met als gevolg dat door toename van de elektriciteitsvraag door intensivering van de belichting ook de inkoop van elektriciteit toenam. Door de gunstige sparkspread voor zowel de productie van elektriciteit voor de verkoop als voor eigen gebruik was het exploitatieresultaat in de recente jaren (vooral 2019 en 2020) voor wkk's gunstig. 


\section{Netto energiekosten gedaald}

$\mathrm{Na}$ een toename in 2017 en 2018 daalden de netto-energiekosten zowel in 2019 en 2020 tot gemiddeld circa $€ 6,50$ per $\mathrm{m}^{2}$ in 2020 (figuur 2.6). In 2019 en 2020 zijn zowel de kosten voor de inkoop als de opbrengsten van de verkoop gedaald. De daling bij de inkoop was sterker dan de verkoop, waardoor de netto-energiekosten in 2020 lager waren dan in 2018.

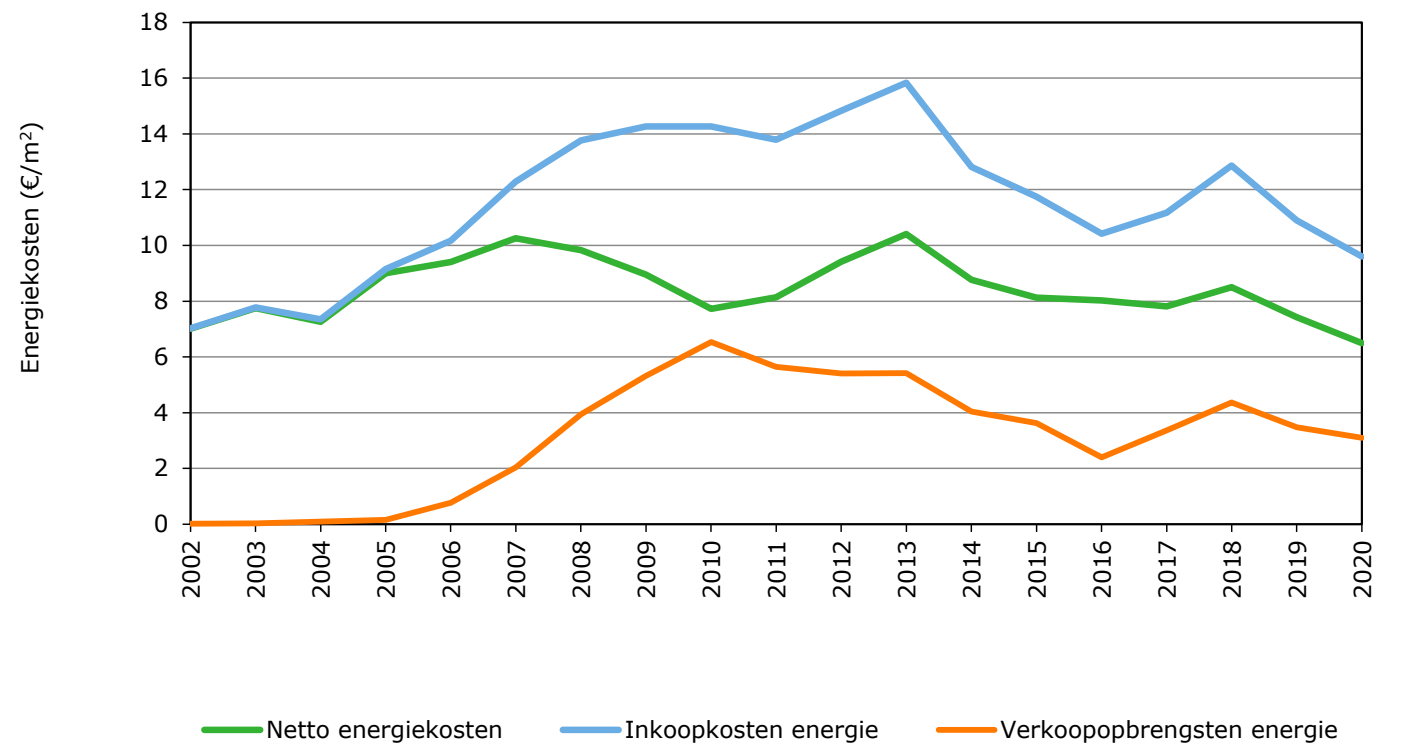

Figuur 2.6 Gemiddelde inkoopkosten, verkoopopbrengsten en netto saldo voor de glastuinbouw $\left.\left(€ / m^{2}\right)^{2} v\right)$

v) Cijfers 2020 voorlopig.

Bron: Bedrijveninformatienet van Wageningen Economic Research.

Door de effecten van coronamaatregelen op de productie en afzet van glastuinbouwproducten en de energiemarkt is 2020 een grillig jaar wat betreft de energievraag en de energieprijzen. Dit laatste betrof vooral de korte termijnmarkt. Hiernaast kregen vooral bedrijven met belichting te maken met de sterk verhoogde ODE-heffing. Op deze veranderingen hebben glastuinbouwbedrijven verschillend gereageerd bij de planning van hun teelt en de inzet van energie.

Overige kosten verbonden aan de energievoorziening nemen toe

Naast de directe kosten voor inkoop en verkoop van energie (zoals weergegeven in figuur 2.6), maken glastuinbouwbedrijven ook andere kosten voor hun energievoorziening. Dit zijn onder andere onderhoudskosten voor energie-installaties, inkoopkosten voor externe $\mathrm{CO}_{2}$ en kosten verbonden aan de investeringen in energievoorzieningen (afschrijving, rente, huur, lease). Vooral door de groei van de inzet van duurzame energie zijn deze kosten de laatste jaren toegenomen.

\subsection{Energiegebruik toegenomen}

Totaal energiegebruik nam in periode $2019 \mathrm{t} / \mathrm{m} 2020$ toe Het totaal energiegebruik van de glastuinbouw liet in de periode $2010 \mathrm{t} / \mathrm{m} 2014$ een dalende trend zien, in de periode 2015 t/m 2018 bleef het min of meer stabiel en in de periode $2019 \mathrm{t} / \mathrm{m} 2020$ nam het toe. De toename in de laatste periode hing vooral samen met de toename van het areaal in de LBT. Het totaal energiegebruik lag in 2020 wel onder het niveau van de jaren voor 2013, het jaar waarna de toename van het energiegebruik wijzigde in een daling.

\footnotetext{
2 De netto-energiekosten zijn het saldo van de nominale kosten voor inkoop minus verkoop.
} 
Energiegebruik per $\mathrm{m}^{2}$ in 2020 licht gestegen

Het gemiddelde energiegebruik per $\mathrm{m}^{2}$ na temperatuurcorrectie daalde in de periode $2000 \mathrm{t} / \mathrm{m} 2014$ met $10 \%$ en nam in de periode 2015 t/m 2018 toe met 7\% (figuur 2.7). In 2019 daalde het totaal energiegebruik per $\mathrm{m}^{2}$ na temperatuurcorrectie naar $1,12 \mathrm{GJ}$ per $\mathrm{m}^{2}(-3 \%)$ om in 2020 licht te stijgen naar $1,13 \mathrm{G}$ ] per $\mathrm{m}^{2}(+1 \%)$. Dit laatste komt overeen met het gemiddelde niveau in de jaren 2010 tot en met 2018.

De energievraag wordt in beginsel niet beïnvloed door de energievoorziening of de herkomst van de energie (fossiel of duurzaam). Door uit te gaan van het energiegebruik per $\mathrm{m}^{2}$ na correctie voor buitentemperatuur, hebben veranderingen in areaal en verschillen in buitentemperatuur geen invloed en resteert de invloed van intensivering, extensivering en energiebesparing op het energiegebruik per $\mathrm{m}^{2}$.

Verhouding warmte en elektriciteit in 2020 verschoven door mutatie areaal en corona effecten Het energiegebruik per $\mathrm{m}^{2}$ na correctie voor de buitentemperatuur is in figuur 2.7 vanaf 2006 opgesplitst in warmte en elektriciteit. Uit het verloop blijkt dat de toename van het totaal energiegebruik per $\mathrm{m}^{2}$ kas in de periode $2014-2018$ (+7\%) voortkwam uit een beperkte groei van het warmtegebruik $(+2 \%)$ en een sterke groei van de elektriciteitsconsumptie $(+29 \%$.) In 2019 nam de warmteconsumptie af $(-4 \%)$ en de elektriciteitsconsumptie toe $(+5 \%)$. In 2020 trad een trendbreuk op; de warmteconsumptie per $\mathrm{m}^{2}$ nam toe $(+5 \%)$ en de elektriciteitsconsumptie nam af $(-8 \%)$. In 2020 bestond circa $76 \%$ van het totale energiegebruik uit warmte en circa $24 \%$ uit elektriciteit; in 2010 was dit $90 \%$ en $10 \%$. Over de afgelopen 10 jaar is er dus een verschuiving opgetreden van warmte- naar elektriciteitsconsumptie. De groei van de elektriciteitsconsumptie per $\mathrm{m}^{2}$ vanaf 2010 komt hoofdzakelijk door intensivering van het gebruik van groeilicht. Er wordt een toenemend areaal belicht $\left(\mathrm{m}^{2}\right)$ en de intensiteit $\left(\mathrm{W} / \mathrm{m}^{2}\right)$ neemt toe. Hiernaast neemt de elektriciteitsconsumptie toe door het gebruik van duurzame energiebronnen, mechanisatie, automatisering en verdere optimalisatie van het kasklimaat (Van der Velden en Smit, 2013).

De trendbreuk in 2020 houdt enerzijds verband met de mutaties van het areaal in de LBT per gewas en anderzijds met anticipatie op de dynamiek van marktvraag in het tweede kwartaal bij de eerste fase van de coronacrisis (incidenteel; een deel van de ondernemers heeft in deze periode het gebruik groeilicht verminderd). Bovendien waren ondernemers in 2020 kritisch ten aanzien van de waarde van het gebruik van groeilicht door onzekerheid van opbrengsten van de oogst en de gestegen kosten voor inkoop elektriciteit (structureel). Dit betrof zowel de commodityprijs als na de verhoging van de Opslag Duurzame Energie- en Klimaattransitie (ODE heffing) op inkoop elektriciteit.

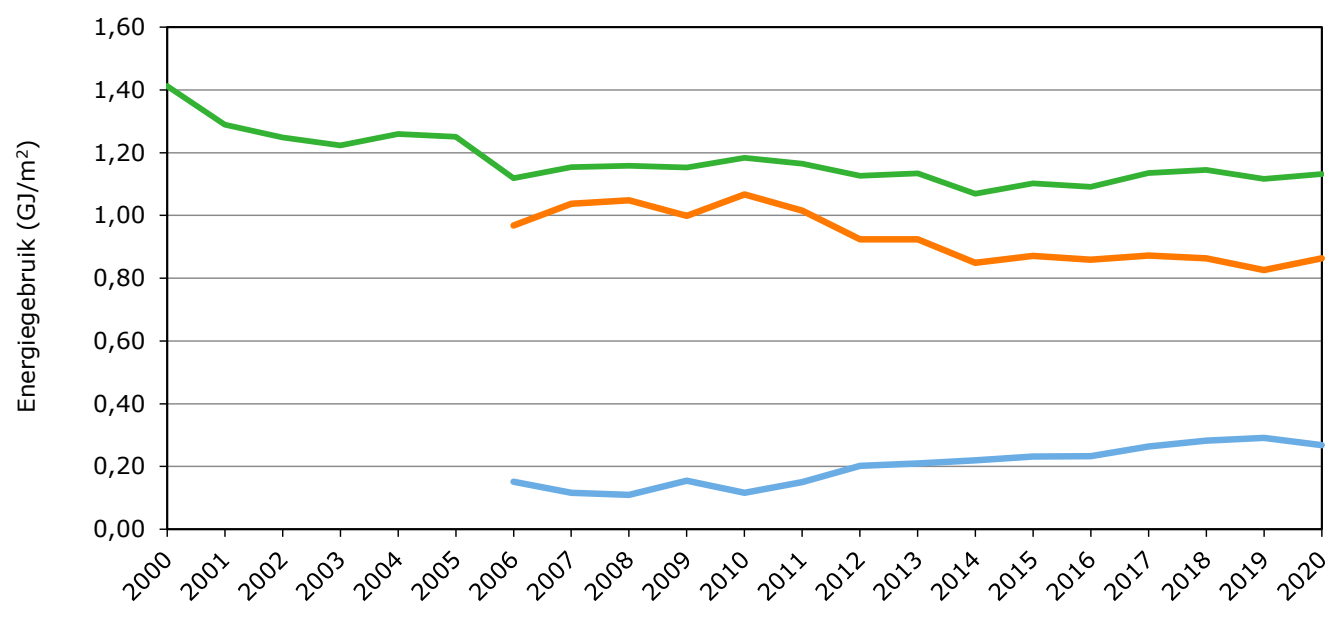

$$
\text { Energiegebruik Warmtegebruik } \longrightarrow \text { Elektriciteitsgebruik }
$$

Figuur 2.7 Gemiddeld energiegebruik per $m^{2}$ na temperatuurcorrectie $v$ )

v) Cijfers 2020 voorlopig. 


\section{Inzet duurzame energie}

\subsection{Duurzame energie is vanuit meerdere hoeken te belichten}

Glastuinbouwbedrijven zijn met partners actief om meer energie uit duurzame energievoorzieningen toe te passen. Dit komt voort uit eigen duurzaamheidsmotieven, het streven te voldoen aan duurzaamheidseisen van klanten of omdat het duurzame alternatief bedrijfseconomisch aantrekkelijker is dan de gangbare fossiele energiebron. In de volgende paragrafen komen achtereenvolgens de toepassing en de ontwikkeling van de afzonderlijke duurzame energiebronnen, de bedrijfsstructuur, de warmtedekking en de $\mathrm{CO}_{2}$-emissiereductie aan bod.

\subsection{Inzet duurzame energiebronnen bleef in beweging}

\subsubsection{Totale inzet duurzame energiebronnen groeit door}

In 2020 werd door de glastuinbouw 11,5 PJ duurzame energie toegepast. Het gebruik van duurzame energie is hiermee in de laatste vijf jaar meer dan verdubbeld (figuur 2.4). De toegepaste duurzame energie bestond voor bijna 93\% uit warmte en voor 7\% uit elektriciteit (tabel 3.1). De duurzame warmte wordt nog steeds vooral door de sector zelf geproduceerd (in $202061 \%$ ) en duurzame elektriciteit wordt vooral buiten de sector ingekocht (in 2020 94\%). De Nederlandse glastuinbouw paste in 2020 zes bronnen van duurzame energie toe. Aardwarmte (37\%) en inkoop van duurzame warmte van derden (36\%) waren de voornaamste bronnen (tabel 3.1 en figuur 3.2). Andere bronnen waren: biobrandstof (13\%), inkoop duurzame elektriciteit $(7 \%)$, herwinning van zonnewarmte $(7 \%)$ en inkoop duurzaam gas $(<1 \%)$ (tabel 3.1$)$.

Tabel 3.1 Toepassing van duurzame energievormen in de Nederlandse glastuinbouw in $2020 \mathrm{v}$ )

\begin{tabular}{|c|c|c|c|c|c|c|c|}
\hline \multirow[t]{2}{*}{ Duurzame energievorm } & \multirow{2}{*}{$\begin{array}{c}\text { Bedrijven a) } \\
\text { Aantal }\end{array}$} & \multirow{2}{*}{$\begin{array}{c}\text { Areaal } \\
\text { ha }\end{array}$} & \multirow{2}{*}{$\begin{array}{l}\text { Gemiddeld } \\
\text { ha per bedrijf }\end{array}$} & \multicolumn{2}{|c|}{ Toepassing } & \multirow{2}{*}{$\begin{array}{c}\text { Totaal } \\
\text { PJ }\end{array}$} & \multirow{2}{*}{$\begin{array}{c}\text { Aandeel } \\
\%\end{array}$} \\
\hline & & & & PJ warmte & TWh elektriciteit & & \\
\hline Aardwarmte & 85 & 964 & 11,3 & 4,2 & - & 4,2 & 37 \\
\hline - warmte & 45 & 371 & 8,3 & 1,3 & - & 1,3 & 11 \\
\hline - warmte en elektriciteit & 6 & 45 & 7,4 & 0,2 & $<, 1$ & 0,2 & 2 \\
\hline - elektriciteit & b) & b) & - & - & 0,2 & 0,8 & 7 \\
\hline - gas & b) & b) & - & 0,0 & - & 0,0 & 0 \\
\hline - warmte & b) & b) & - & 4,1 & - & 4,1 & 36 \\
\hline .waarvan centraal & b) & b) & - & $(1,1)$ & - & $(1,1)$ & (9) \\
\hline - warmte & 61 & 212 & 3,5 & 0,8 & - & 0,8 & 7 \\
\hline Totaal c) & 336 & 1.990 & 5,9 & 10,6 & 0,2 & 11,5 & 100 \\
\hline
\end{tabular}
a) Peildatum eind 2020 .
b) Cijfers niet bekend.
c) Als meerdere vormen van duurzame energie op een bedrijf worden toegepast is dat eenmaal meegenomen in het totaal.
v) Voorlopige cijfers. 
In 2020 is het totale gebruik van duurzame energie gegroeid met 1,15PJ. De groei was het saldo van nieuwe projecten, aanpassing van bestaande projecten, projectbeëindiging en verandering van de inkoop. De groei is minder sterk dan in 2019, toen het gebruik met 1,37 PJ toenam. Vooral de hoeveelheden inkoop van duurzame warmte en de inzet van biobrandstof namen toe (figuur 3.1). De inzet van aardwarmte geëxploiteerd door de glastuinbouw liet een lichte stijging zien. De toepassing van zelf opgewekte zonne-elektriciteit groeide door, maar bleef qua hoeveelheid beperkt. De inkoop van duurzaam gas en de inzet van zonnewarmte waren stabiel. De inkoop van duurzame elektriciteit daalde voor het derde jaar op rij.

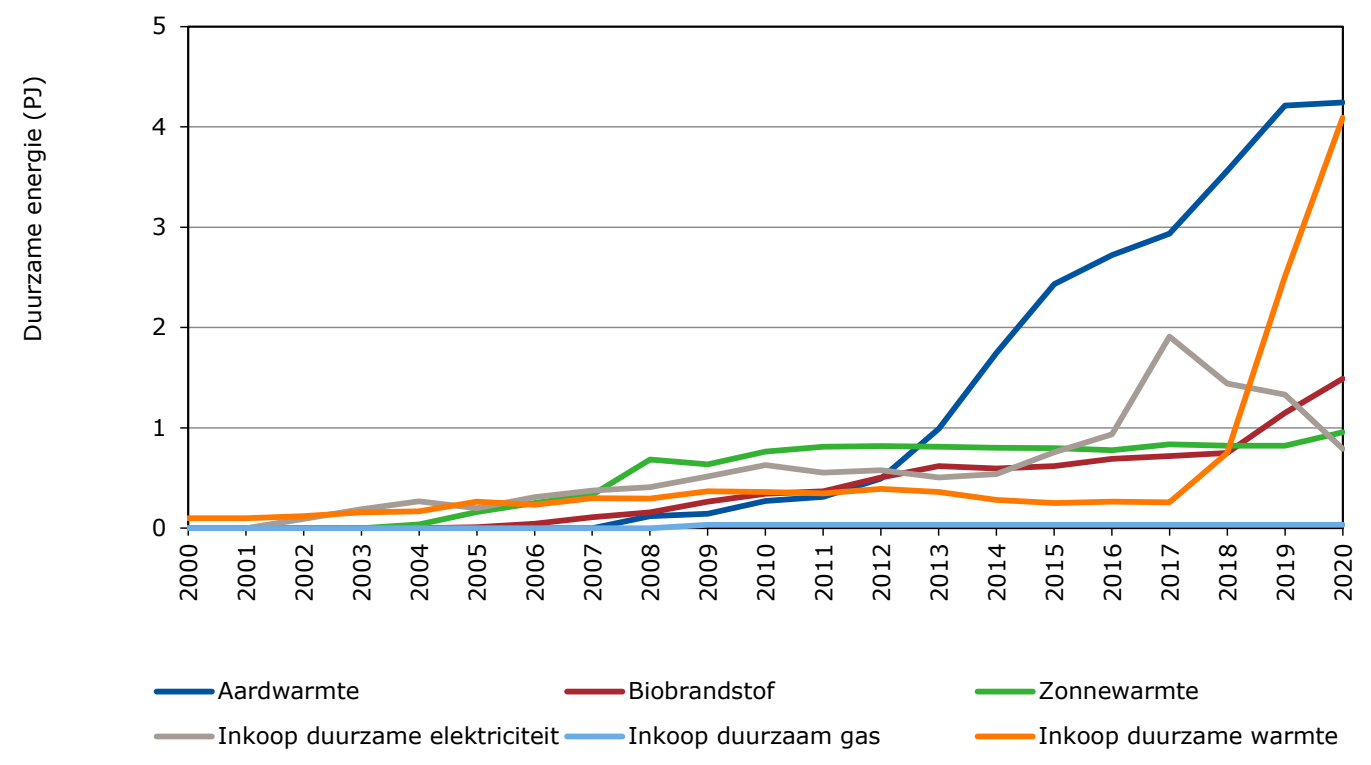

Figuur 3.1 Ontwikkeling van het gebruik van duurzame energie in de glastuinbouw per bron per jaar (PJ) v)

v) Cijfers 2020 voorlopig.

\subsubsection{Ontwikkelingen verschillen sterk per duurzame energiebron}

\section{Aardwarmte}

In 2020 was de stijging van de hoeveelheid toegepaste geothermie die door de glastuinbouw zelf werd geproduceerd beperkt (1\%). Dit kwam doordat er projecten in onderhoud waren, er geen nieuwe projecten in eigen beheer in gebruik werden genomen en de bestaande projecten samen per saldo een globaal gelijke productie hadden. De inzet van aardwarmte uit projecten geëxploiteerd door partijen buiten de glastuinbouw nam wel toe. Dit komt aan bod bij 'Inkoop van duurzame energie' en hoofdstuk 5 .

Eind 2020 waren er 19 aardwarmtedoubletten door de glastuinbouw in beheer en deze leverden aan 85 bedrijven aardwarmte. Hiervan waren er 63 risicodragend deelnemer (exploitant) en 22 afnemer. Het areaal glastuinbouw met aardwarmte groeide naar 964 ha, 94\% hiervan was van de glastuinbouwexploitanten en $6 \%$ van glastuinbouwbedrijven die aardwarmte bij hun collega's inkochten. Hiermee werd in 2020 op bijna $10 \%$ van het totaal areaal glastuinbouw in Nederland door de sector geproduceerde aardwarmte toegepast. Op circa $85 \%$ van dit areaal werd groente geteeld. Dit hangt onder meer samen met de warmtevraag bij groenteteelt in combinatie met de schaalgrootte van deze bedrijven.

In 2020 waren niet alle projecten het volledige jaar of met het ontwerpvermogen in bedrijf. Dit kwam doordat nieuwe projecten in de loop van het jaar werden opgestart en bestaande projecten te maken hadden met onderhoud, storingen en andere onderbrekingen. De gemiddelde inzet van aardwarmte 
per $\mathrm{m}^{2}$ kas was met 0,44 GJ (circa $14 \mathrm{~m}^{3}$ a.e.) in 2020 iets lager dan in 2019. Het areaal met aardwarmte steeg meer dan de hoeveelheid toegepaste warmte.

\section{Zonne-energie}

De toepassing van herwonnen zonnewarmte was in 2020 stabiel. Er kon door relatief veel zoninstraling en hoge buitentemperaturen veel warmte gewonnen worden. Echter het was door diezelfde hoge instraling en warmte een opgave om de herwonnen warmte ook toe te passen. Dit werd versterkt door warmte beschikbaar uit het eveneens warme vorige jaar.

In totaal werd zonnewarmte toegepast door 61 bedrijven met een gezamenlijk glasareaal van 212 ha. Herwinning zonnewarmte ontwikkelt zich al jaren alleen nog bij bedrijven waarbij koude nodig is voor koeling van de teelt. De zonnewarmte werd vooral toegepast bij plantenbedrijven (56\%), op afstand gevolgd door bloemen (22\%) en groente (17\%). Bij bloemen waren alle bedrijven met herwinning van zonnewarmte uit grondkoeling te vinden, hoofdzakelijk bij de gewassen alstroemeria, amaryllis en freesia. Bij planten betreft het hoofdzakelijk de teelt van phalaenopsis. Op circa de helft van het totale areaal van deze vier gewassen wordt koeling gecombineerd met herwinning van zonnewarmte. Ook passen enkele bedrijven met uitgangsmateriaal herwinning van zonnewarmte toe.

In 2020 groeide het aantal bedrijven met winning van elektriciteit via fotovoltaïsche cellen (zon PV) verder door. De toepassing groeide door het toegenomen vermogen en door de grote hoeveelheid zonlicht in de lente en zomer met meer dan de helft. Bij toepassing van duurzame elektriciteit vanuit eigen productie door de glastuinbouw is zonne-elektriciteit sinds 2017 de voornaamste bron. De gewonnen elektriciteit werd voor circa driekwart toegepast op de bedrijven en de rest werd verkocht. Zonne-elektriciteit groeit mede doorstimuleringsregelingen. Het aandeel van zon-elektrische energie in de totale hoeveelheid toegepaste, duurzame elektriciteit blijft met $5 \%$ ondanks de groei nog beperkt. Deze beperkte hoeveelheid komt enerzijds doordat kasdekken niet gebruikt kunnen worden, omdat het licht essentieel is voor de groei het gewas. Anderzijds zit de elektriciteitsvraag van de glastuinbouw vooral in perioden waarin het zonlicht beperkt of afwezig is (winter en nacht).

\section{Biobrandstof}

Het aantal glastuinbouwbedrijven dat in 2020 biobrandstof toepaste, steeg naar 51 en het areaal naar 416 ha. Hiervan gebruikten 6 bedrijven met een gezamenlijk areaal van 45 ha biobrandstof in een wkk. Van het areaal met biobrandstof in ketels was 307 ha te vinden bij de teelt van groenten, 83 ha bij planten en 25 ha bij bloemen. Hout is al jaren de voornaamste biobrandstof voor de glastuinbouw. Er gebruikten 46 bedrijven resthout uit industrie of snoeihout uit groenbeheer als brandstof. Drie bedrijven haalden hun biobrandstof uit vergisting en zetten deze met een bio-wkk om naar warmte en elektriciteit. In 2020 namen 48 glastuinbouwbedrijven deel aan de exploitatie van een installatie op biobrandstof. Vanuit deze projecten werd aan 3 andere glastuinbouwbedrijven warmte geleverd. De combinatie van een onzekere en relatief hoge biobrandstofprijs en een relatief lage aardgasprijs leidde vooral bij bestaande projecten vaker tot stevige bedrijfseconomische afwegingen tussen de inzet van biobrandstof en de inzet van aardgas met wkk. Hiernaast zijn voor de toekomstonzekerheden vanuit het stikstof-dossier en het maatschappelijk debat rondom de beoordeling van biomassa als duurzame energiebron relevant.

Per saldo steeg de toepassing van energie uit biobrandstof in 2020 met bijna 30\%. Dit kwam doordat nieuwe relatief grote projecten in gebruik zijn genomen en de gebruiksduur van bestaande installaties toenam. De inzet van energie uit biobrandstof vanuit projecten geëxploiteerd door partijen buiten de glastuinbouw nam eveneens toe. Dit wordt verder behandeld bij 'Inkoop van duurzame energie' en hoofdstuk 5 .

\section{Inkoop van duurzame energie}

Door de glastuinbouw wordt naast eigen productie ook duurzame elektriciteit, duurzame warmte en duurzaam gas ingekocht. Dit vindt plaats vanuit lokale projecten en door inkoop vanuit openbare netten.

De duurzaamheid van ingekochte duurzame elektriciteit en duurzaam gas uit openbare netten wordt met Garanties van Oorsprong (GVO) gewaarborgd. Glastuinbouwbedrijven kopen duurzame 
elektriciteit in vanuit eigen motieven of om te voldoen aan regelingen en keurmerken waarbij een mate van duurzaamheid een vereiste is.

De inkoop van duurzame elektriciteit daalde in 2020, net als in 2019. Er werd in 2020220 miljoen kWh ingekocht. De hogere kosten voor de inkoop van duurzame elektriciteit ten opzichte van gangbare elektriciteit speelt hierbij een rol, maar ook de groei van eigen opwekking met zonnepanelen.

Inkoop van duurzame warmte vindt plaats vanuit centrale en decentrale projecten. Centrale inkoop betreft warmte waarbij bij de opwekking een deel biobrandstof worden ingezet of warmte die wordt bijgemengd met warmte uit duurzame bronnen (aardwarmte en biobrandstof). Bij decentrale projecten wordt op kleinere schaal lokaal duurzame warmte uit biobrandstof door exploitanten van installaties van buiten de sector geleverd aan glastuinbouwbedrijven.

Sterke groei was er wederom bij de inkoop van duurzame warmte: van 2,5 PJ in 2019 naar 4,1 PJ in 2020. Hiermee was meer dan de helft van alle warmte ingekocht bij derden door tuinders van duurzame oorsprong. Deze groei kwam enerzijds door de ingebruikname van nieuwe, relatief grote, decentrale installaties in de directe nabijheid van glastuinbouwbedrijven en anderzijds door verdere toename van de duurzame fractie bij centrale warmtelevering (hoofdstuk 5). Het areaal met lokale inkoop duurzame warmte is in 2020 uitgekomen op 950 ha. Het areaal met centrale inkoop van duurzame warmte is geschat op circa 375 ha.

Meer dan $46 \%$ van de duurzame warmte ingekocht bij derden betrof in 2020 aardwarmte, de overige $54 \%$ komt van biobrandstof. De toegepaste aardwarmte in de glastuinbouw was hiermee voor ruim $30 \%$ afkomstig van projecten die worden geëxploiteerd door partijen van buiten de sector. Bij biobrandstof was dit aandeel ruim $40 \%$.

Duurzaam gas betreft biogas dat is geproduceerd en geconverteerd naar een standaardkwaliteit, waardoor gas met GVO via het aardgasnet gekocht kan worden door de eindverbruiker. De aankoopmotieven voor de inkoop van duurzaam gas zijn globaal gelijk aan die voor de inkoop van duurzame elektriciteit. De kosten voor de inkoop van duurzaam gas zijn in vergelijking met duurzame elektriciteit hoog, mede hierdoor bleef het gebruik van duurzaam gas in 2020 net als in eerdere jaren zeer beperkt.

Samenwerking en economische afwegingen meer bepalend voor de inzet van duurzame energie Een belangrijke ontwikkeling uit 2018 en 2019 zette zich in 2020 voort: Samenwerking. Projecten met duurzame energie worden de laatste jaren vooral in samenwerking ontwikkeld. Dit kan zijn tussen glastuinbouwbedrijven onderling, maar ook met partijen van buiten de sector zoals leveranciers van installaties, energiebedrijven en andere externe exploitanten.

Tot 2010 kwamen duurzame energieprojecten vooral tot stand door inspanningen van tuinders die als pionier gekarakteriseerd konden worden. In de periode hierna tot circa 2015 werden duurzame energieprojecten steeds vaker gerealiseerd door het gezamenlijk optrekken van glastuinbouwbedrijven gevestigd in elkaars nabijheid. Hiermee konden grotere, efficiëntere projecten worden gerealiseerd en werden projectrisico's beter beheersbaar. Na 2015 zijn met dezelfde motieven en de kansen die duurzame energie voor partijen buiten de glastuinbouw bieden de volgende stappen gezet. Glastuinbouwbedrijven realiseerden met partners van buiten de sector gezamenlijk projecten. Hierbij zijn er projecten waarbij zowel de betrokken tuinders als de derde partij risicodragend deelnemen. Ook zijn er projecten waarbij tuinders zich beperken tot aankoop van duurzame energie en de exploitatie volledig in handen is van de partij van buiten de sector. Mede door deze samenwerking en betrokkenheid van partijen van buiten de sector konden projecten gerealiseerd worden met een groter vermogen. In combinatie met het aanleggen van lokale warmtedistributie kon het areaal met duurzame energie verder doorgroeien. De groei van 'Inkoop duurzame energie' (bijna $85 \%$ ten opzichte van 2019) en de stijging van het aandeel inkoop van buiten de sector (in drie jaar van $30 \%$ naar $42 \%$ ) illustreren dit. De energietransitie wordt hiermee steeds meer een cross-sectoraal proces van glastuinbouwbedrijven samen met energiepartners en andere lokale betrokkenen. 
Een ander aspect dat de ontwikkeling van de toepassing van duurzame energie beïnvloedt, zijn de bedrijfseconomische mogelijkheden in vergelijking met gangbare energievoorzieningen. De toepassing van duurzame energie is in de glastuinbouw hoofdzakelijk warmte (93\%). Duurzame warmte concurreert in economisch opzicht met gangbare bronnen. In de glastuinbouw zijn dit vooral de aardgas wkk's. Vanaf 2017 is door de verbeterde spark spread het bedrijfseconomisch voordeel van aardgas wkk ten opzichte van duurzame bronnen versterkt (hoofdstuk 4). Dit kwam door de relatief lage gasprijs in combinatie met relatief hogere elektriciteitsprijs. Voor gebruik van elektriciteit kwam hier de gestegen ODE-heffing vanaf 2019 bij. Ook spelen lopende financieringsverplichtingen voor bestaande wkk's een belangrijke rol. Als de afgelopen jaren duurzame warmtebronnen door ondernemers op enkel economische gronden werden afgewogen tegen aardgas wkk dan waren uitkomsten voor de duurzame warmtebronnen vaak ongunstig.

Omdat bij de start van de ontwikkeling van duurzame energieprojecten andere bedrijfseconomische veronderstellingen actueel waren, het aspect van duurzaamheid meeweegt en er naast de warmte die aardgas wkk kan produceren nog meer warmtevraag is, zijn er wel projecten gerealiseerd. Dit resulteerde dan vaak in een verschuiving van eigen productie met aardgas wkk naar gebruik van duurzame warmte, inkoop van elektriciteit en inkoop van externe $\mathrm{CO}_{2}$. In de actuele situatie lopen bedrijven die duurzame warmtebronnen willen exploiteren tegen grenzen aan als zij het perspectief van voldoende bedrijfseconomisch rendement beoordelen. Dit remt initiatieven voor verdere groei van duurzame warmte in de glastuinbouw bij tuinders en hun partners.

\subsubsection{Stijging van productie, inkoop, verkoop en consumptie duurzame energie}

De productie, inkoop, verkoop en consumptie van duurzame energie in 2020 is samengevat in figuur 3.2. Deze balans laat zien dat de consumptie van duurzame energie voor meer dan de helft gedekt werd door eigen productie en voor ruim een derde werd ingekocht bij partijen buiten de sector. De door de glastuinbouw zelf geproduceerde, duurzame energie (6,9 PJ) werd voor een klein deel $(10 \%)$ verkocht. Verkoop vond plaats aan glastuinbouwbedrijven en aan partijen buiten de sector. De inkoop van duurzame energie van buiten de sector groeide ook in 2020; met circa $25 \%$. Deze groei was sterker dan de groei van de eigen productie die circa $10 \%$ bedroeg. Per saldo steeg het aandeel inkoop in de consumptie van duurzame energie in 2020 van 39 naar 42\% (figuur 3.3). Dit aandeel nam sinds 2014 toe en onderschrijft het belang van partijen van buiten de sector bij de energietransitie van de glastuinbouw.

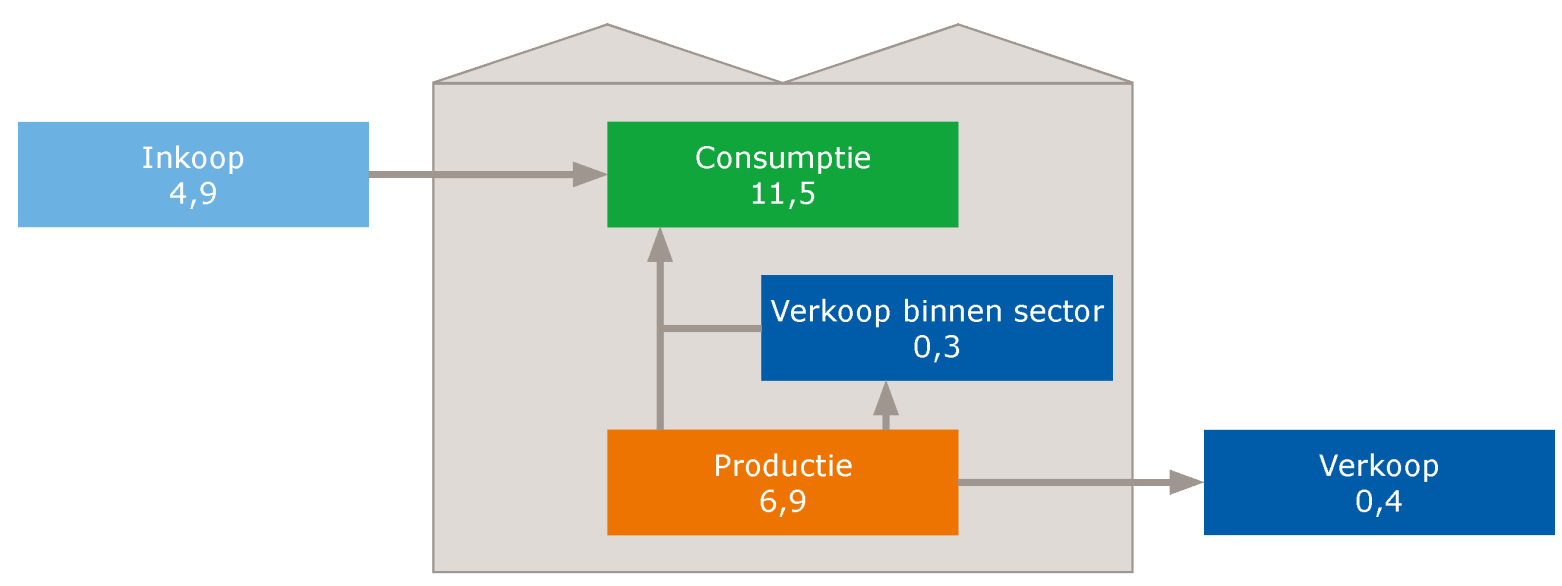

Figuur 3.2 Balans voor duurzame energie van de Nederlandse glastuinbouw in 2020 (PJ) v) v) Cijfers voorlopig. 


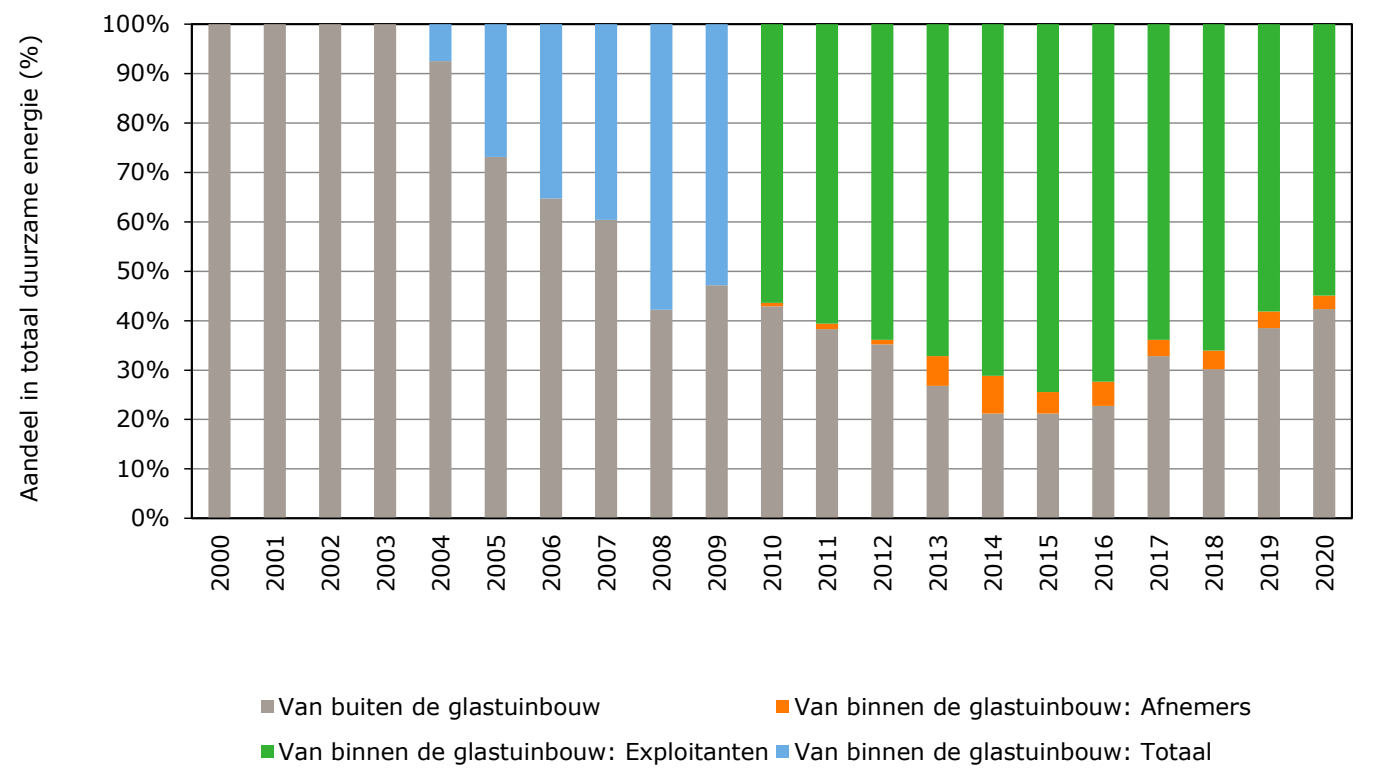

Figuur 3.3 Verdeling van de aandelen toegepaste duurzame energie naar herkomst per jaar (\%) a), v) a) Vanaf 2010 is toepassing van door de sector geproduceerde duurzame energie opgesplitst naar exploitanten en afnemers.

v) Cijfers 2020 voorlopig.

\subsubsection{Bijna $20 \%$ van het glastuinbouwareaal gebruikt duurzame energie}

\section{Areaal en aantal bedrijven met duurzame energie stijgt door}

Het totaal areaal met gebruik van duurzame energie bedraagt in 2020 bijna 2.000 ha (tabel 3.1). Dit is exclusief inkoop duurzame elektriciteit, duurzaam gas en centraal geleverde duurzame warmte. Dit betekent dat in 2020 circa een vijfde van het totaal areaal glastuinbouw gebruik maakt van duurzame energie. Van het areaal met duurzame energie past circa $85 \%$ duurzame warmte toe.

Het aantal bedrijven met gebruik van duurzame energie (exclusief inkoop uit openbare netten) groeide in 2020 met 10\% naar 336). Deze groei was het saldo van de start van nieuwe projecten, continuering van bestaande projecten en projecten die werden beëindigd. De bedrijven omvatten een areaal van 1990 ha en bijna $20 \%$ van totale areaal glastuinbouw in Nederland. De groei komt vooral doordat meer bedrijven zijn aangesloten op bronnen die meerdere bedrijven of zelfs op gebiedsniveau duurzame warmte kunnen leveren. Ook was er groei bij decentrale duurzame warmte-inkoop en zijn er nieuwe projecten waar zonne-elektriciteit wordt ingezet. In 2020 was de gemiddelde omvang van een glastuinbouwbedrijf met duurzame energie 6 ha; dit is meer dan twee keer de gemiddelde bedrijfsomvang in de sector (figuur 3.5). De groei van de gemiddelde omvang van bedrijven met duurzame energie werd gedempt door de groei van de toepassing van zonne-elektriciteit op kleinere bedrijven. 


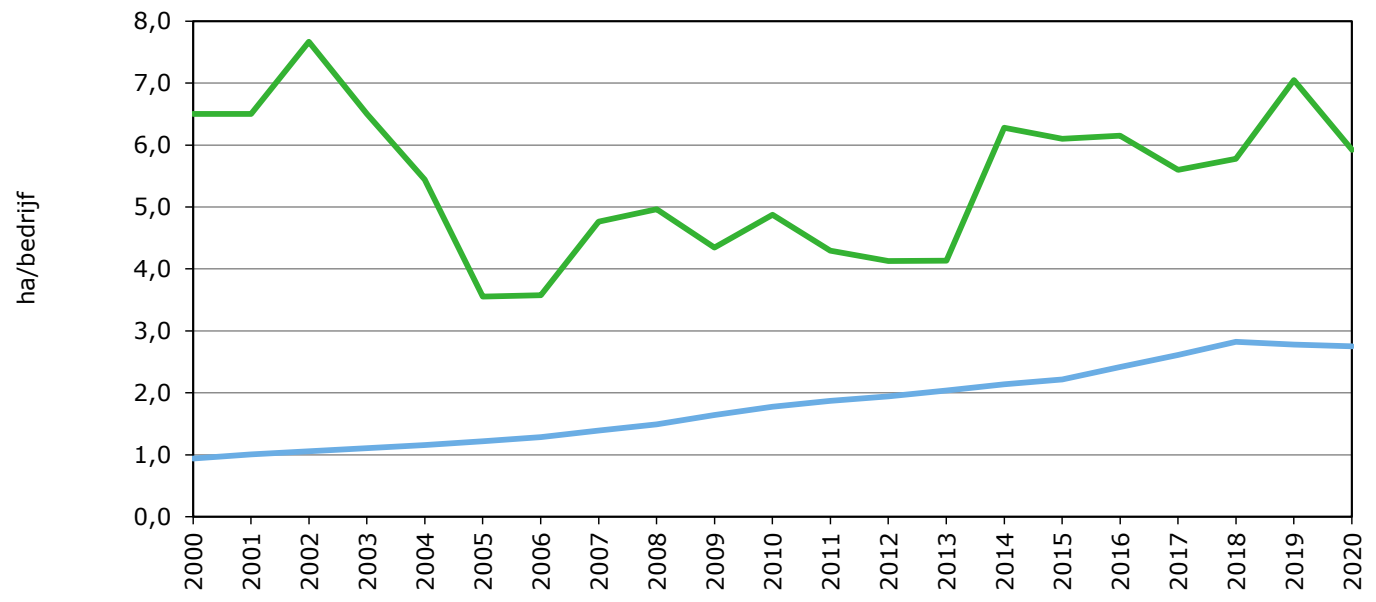

Gemiddeld areaal van glastuinbouwbedrijven met toepassing van duurzame energie

Gemiddeld glasareaal van bedrijven met glastuinbouw

Figuur 3.4 Ontwikkeling van de gemiddelde omvang van glastuinbouwbedrijven met duurzame energie en de gemiddelde omvang van bedrijven met glastuinbouw (ha)a), v)

a) Exclusief bedrijven met enkel inkoop van duurzame energie uit openbare netten.

v) Cijfers 2020 voorlopig.

Inzet duurzame energie vooral bij grotere bedrijven in groente- en plantenteelt In elk van de vier subsectoren in de glastuinbouw wordt duurzame energie toegepast. De meeste toepassing vond ook in 2020 plaats bij de groenteteelt (72\%) en het minst bij uitgangsmateriaal (3\%). Deze subsectoren zijn qua areaal in Nederland ook de grootste en de kleinste. De arealen met duurzame energie bij bloemen (6\%) en bij planten (20\%) zaten hier tussen.

Bij de teelt van bloemen wordt gemiddeld minder warmte en meer groeilicht toegepast en in de vraag naar elektriciteit wordt voor een belangrijk deel voorzien met aardgas-wkk. Hierdoor is het complexer om bij bloemenbedrijven duurzame energie toe te passen. Bij groentebedrijven wordt meer $\mathrm{CO}_{2}-$ gedoseerd met wkk en ook dit concurreert met duurzame energie. Door de toename van groeilicht in deze subsector wordt enerzijds ook hier de inzet van duurzame warmte complexer. Anderzijds zijn groentebedrijven vaak relatief groot en die schaalgrootte is gunstig voor de bedrijfseconomische mogelijkheden van duurzame energieprojecten. Er zijn relatief veel potplantenbedrijven die een relatief hoge kastemperatuur hanteren, minder intensief belichten en minder $\mathrm{CO}_{2}$ doseren. Hierdoor ondervindt duurzame energie op deze plantenbedrijven minder concurrentie van aardgasgestookte ketels en wkk. Daarentegen zijn de bedrijven in deze subsector kleiner. Het areaal met duurzame energie over de subsectoren nam de laatste jaren vooral toe bij groente en planten.

Het grootste deel van de toepassing van duurzame energie door glastuinbouwbedrijven vindt plaats op grotere bedrijven. Ruim $83 \%$ van de duurzame energie wordt toegepast op bedrijven met meer dan 4 ha kassen (figuur 3.6). De hoeveelheid duurzame energie toegepast door kleine (1-2 ha) en zeer kleine ( $<1$ ha) bedrijven bedroeg in 2020 ruim $5 \%$. Het aandeel van grotere bedrijven neemt toe en het aandeel van de kleinere bedrijven neemt af. Dit hangt samen met de schaalvergroting in de sector en met de relatief hoge investeringen die gepaard gaan met duurzame energie, waardoor dit voor kleinere bedrijven moeilijker te realiseren is. Van de bedrijven die in 2020 duurzame energie toepasten, hadden er 60 een areaal groter dan 8 ha. Deze bedrijven pasten vooral aardwarmte toe en kochten duurzame warmte van derden. De toepassing door kleine en zeer kleine bedrijven was hoofdzakelijk warmte uit biobrandstof en zonne-energie. 


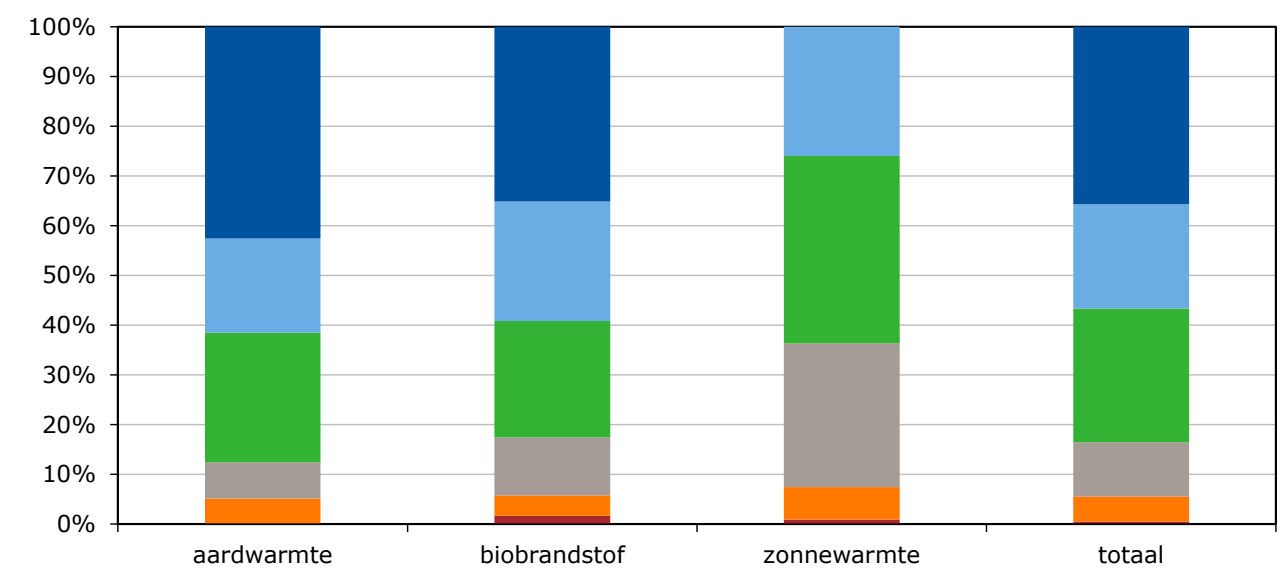

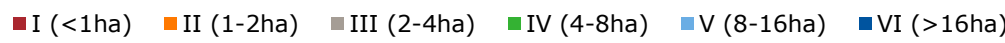

Figuur 3.5 Toegepaste warmte uit aardwarmte, biobrandstof en zon verdeeld over bedrijfsgrootteklassen van projecten in exploitatie door glastuinbouwondernemers in 2020 (\%) a), v) a) exclusief inkoop duurzame warmte

v) Cijfers voorlopig.

\section{3 $\mathrm{CO}_{2}$-emissiereductie door duurzame energie in 2020 verder gegroeid}

Productie, inkoop en verkoop van duurzame energie door de glastuinbouw reduceert zowel binnen als buiten de glastuinbouw de $\mathrm{CO}_{2}$-emissie. Verandering van de $\mathrm{CO}_{2}$-emissie kan zowel op sectorniveau (op basis van de IPCC-methode) als op nationaal niveau (op basis van het primair brandstofverbruik) worden uitgedrukt. De reductie van de $\mathrm{CO}_{2}$-emissie door duurzame energie op sectorniveau bedroeg in 2020 0,58 Mton en de nationale reductie 0,65 Mton (tabel 3.2). Zowel op sectorniveau als op nationaal niveau kwam de grootste bijdrage van aardwarmte en inkoop duurzame warmte. Op nationaal niveau was inkoop van duurzame elektriciteit ook belangrijk. Dit komt doordat inkoop en productie van duurzame elektriciteit inkoop van niet-duurzame elektriciteit vervangt en de inkoop van elektriciteit bij de IPCC-methode niet tot emissietoekenning aan de glastuinbouwsector leidt.

Tabel 3.2 Reductie $\mathrm{CO}_{2}$-emissie door duurzame energie per bron in $2020 \mathrm{v}$ )

\begin{tabular}{lrrr} 
Duurzame energiebron & Sectoraal $/$ IPPC methode & National / Primair Brandstof methode & Mton \\
\cline { 2 - 4 } Aardwarmte & Mton & $\%$ & $-0,23$ \\
\hline Biobrandstof (warmte en elektriciteit) & $-0,23$ & 40 & $-0,01$ \\
\hline Biobrandstof (warmte) & $-0,01$ & 2 & $-0,07$ \\
\hline Zonne-energie (elektriciteit) & $-0,07$ & 12 & 0,00 \\
\hline Zonne-energie (warmte) & 0,00 & 0 & $-0,02$ \\
\hline Inkoop duurzame warmte (centraal) & $-0,04$ & 7 & $-0,06$ \\
\hline Inkoop duurzame warmte (lokaal) & $-0,06$ & 10 & $-0,16$ \\
\hline Inkoop duurzame elektriciteit & $-0,17$ & 29 & $-0,10$ \\
\hline Inkoop duurzaam gas & 0,00 & 0 & $\mathbf{3}$ \\
\hline Totaal & 0,00 & 0 & $\mathbf{2 5}$ \\
\hline
\end{tabular}

v) Cijfers voorlopig. 
In 2020 was op sectorniveau de $\mathrm{CO}_{2}$-emissiereductie door de productie van duurzame energie anderhalf keer groter dan de reductie door inkoop van duurzame energie. Op nationaal niveau was de reductie door duurzame energieproductie door de sector zelf globaal gelijk aan de reductie door inkoop van buiten de sector. Over alle jaren is de reductie op nationaal niveau groter dan op sectorniveau. Dit komt doordat op nationaal niveau de inkoop en verkoop van duurzame elektriciteit wel meetelt. Duurzame energie had in 2020 een positieve bijdrage aan verbetering van de energie-efficiëntie van de glastuinbouw met 5 procentpunten.

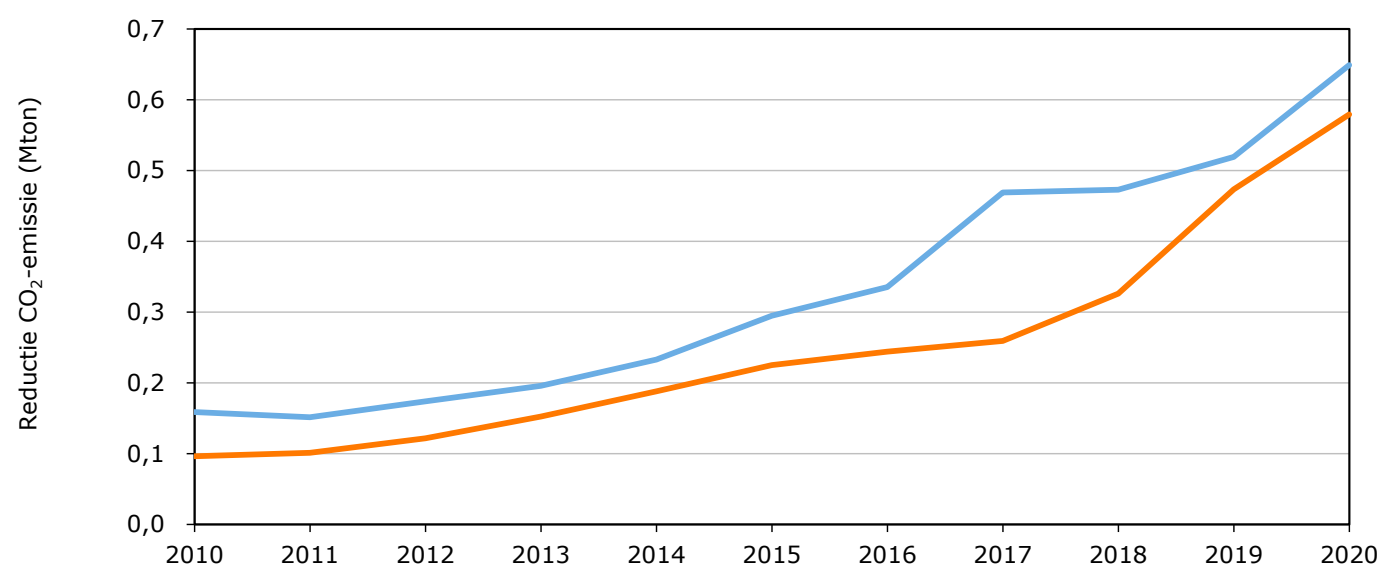

Figuur 3.6 Ontwikkeling $\mathrm{CO}_{2}$-emissiereductie door duurzame energie in de glastuinbouw volgens IPCC- en primair brandstofmethode $v$ )

v) Cijfers 2020 voorlopig.

\subsection{Warmtedekking vaak beperkt tot basislast}

Duurzame warmtebronnen voorzien in de glastuinbouw op het areaal waar de bronnen worden ingezet een deel van de warmtevraag. De mate waarin in de warmtevraag wordt voorzien wordt de warmtedekking genoemd en kan worden uitgedrukt in $\mathrm{m}^{3}$ aardgasequivalenten (a.e.) per $\mathrm{m}^{2}$ per jaar. De dekking bepaalt de reductie van de $\mathrm{CO}_{2}$-emissie in $\mathrm{kg} \mathrm{CO}_{2}$ per $\mathrm{m}^{2}$ kas door de duurzame warmtebron en wordt beïnvloed door: (1) de warmtevraag op het glastuinbouwbedrijf, (2) het absolute vermogen van de duurzame energiebron, (3) het areaal dat de bron van warmte voorziet, (4) de gebruiksduur van de bron en (5) de $\mathrm{CO}_{2}$-voorziening. In 2020 was de gemiddelde dekking met duurzame warmte op het areaal met deze bronnen $10 \mathrm{~m}^{3}$ a.e. per $\mathrm{m}^{2}$ Dit is bijna een kwart minder dan in 2019. Dit kwam omdat de groei van het areaal waarop het vermogen van duurzame warmtebronnen wordt ingezet sterker toenam dan de hoeveelheid toegepaste duurzame warmte.

\section{Verschillen warmtedekking tussen warmtebronnen}

Rondom de gemiddelde warmtedekking zit spreiding: Het verschilt per duurzame bron en per project. Bij projecten met zonnewarmte is de dekking gemiddeld laag en de spreiding tussen projecten klein. Dit komt door de functionele verbinding met de teelt (koeling is de primaire functie). Bij projecten met inkoop van centrale warmte bijgemengd met duurzame warmte is de dekking relatief hoog en de spreiding klein. Dit komt door hogere capaciteiten per $\mathrm{m}^{2}$, gelijksoortige contractvoorwaarden en afspraken tussen afnemer en leverancier. Bij projecten met aardwarmte, biobrandstof en lokale duurzame warmtelevering zit de dekking hier tussenin en is de spreiding groot. De lagere dekking heeft meerdere oorzaken. Ten eerste hebben deze bronnen geen functionele verbinding met de teelt, zoals bij zonnewarmte. Ten tweede is bij deze bronnen de projectoptimalisatie gericht op de bron. Er zijn projecten met aardwarmte en biobrandstof die ingericht zijn om een maximale invulling van de 
warmtevraag per $\mathrm{m}^{2}$ op het glastuinbouwbedrijf te realiseren en er zijn projecten die een maximale benutting van de warmtebron nastreven. Bij maximale invulling is de dekking hoger, maar is er -

vooral in de zomer - onbenut warmtevermogen van de bron. Bij maximale benutting van de bron is de capaciteit van de bron per $\mathrm{m}^{2}$ kleiner, de gebruiksduur langer en de dekking lager. Hierdoor is er in de winterperiode meer warmte nodig vanuit andere warmtebronnen. Uit de spreiding tussen de afzonderlijke projecten met aardwarmte en biobrandstof kan worden afgeleid dat een hogere warmte dekking technisch mogelijk is.

In de praktijk steeds vaker maximale benutting duurzame warmtebron

Deze variant is vooral de laatste jaren populair. Enerzijds is bij maximale benutting de gebruiksduur langer waardoor de kosteneffectiviteit en daardoor is ondersteuning vanuit de SDE+-regeling meer kansrijk is. Bij het maximeren van de gebruiksduur van een warmtebron hoort een kleinere warmtecapaciteit $\left(\mathrm{W} / \mathrm{m}^{2}\right)$ over relatief veel areaal en hierdoor is de bijbehorende warmtedekking laag. Anderzijds is het voor projectpartners en financiers belangrijk dat projectrisico's door meerdere deelnemers wordt gedragen. Voor aardwarmte komt hier nog bij dat de mate van regelbaarheid beperkt is, in vergelijking met bijvoorbeeld aardgas wkk. Ook is belangrijk dat op bedrijven met belichting gasgestookte wkk's elektriciteit en rookgas $\mathrm{CO}_{2}$ kunnen blijven produceren en de warmte die hierbij vrijkomt benut kan blijven worden. In 2020 werd naar schatting op ruim driekwart van het areaal met duurzame warmte ook warmte, elektriciteit en $\mathrm{CO}_{2}$ vanuit aardgas wkk of niet-duurzame warmte van derden toegepast. Hiernaast heeft het grootste deel van het areaal met duurzame warmte zonder wkk toegang tot externe $\mathrm{CO}_{2}$.

\section{Gerealiseerde warmtedekking dalende}

De warmtedekking van de afzonderlijke duurzame warmtebronnen verschilt per project. Ook is de mix van de afzonderlijke bronnen in de totale hoeveelheid duurzame warmte de afgelopen jaren veranderd. Hierdoor dient de ontwikkeling van de gemiddelde dekking in de tijd per bron te worden bezien. Uit de achterliggende data van de projecten met duurzame warmte (paragraaf 3.2) blijkt dat de gemiddelde dekking van de meeste duurzame warmtebronnen in de periode $2014 \mathrm{t} / \mathrm{m} 2020$ ten opzichte van de periode 2010 t/m 2013 is gedaald. Dit is vanaf 2018 nog duidelijker, vooral bij de voornaamste bronnen van duurzame warmte. Een illustratie hiervan is in figuur 3.8 weergegeven voor aardwarmte en inkoop duurzame warmte. De belangrijkste oorzaak hiervan is de opzet van de regeling van de SDE-subsidie. Hiernaast speelt parallelle inzet van wkk een rol.

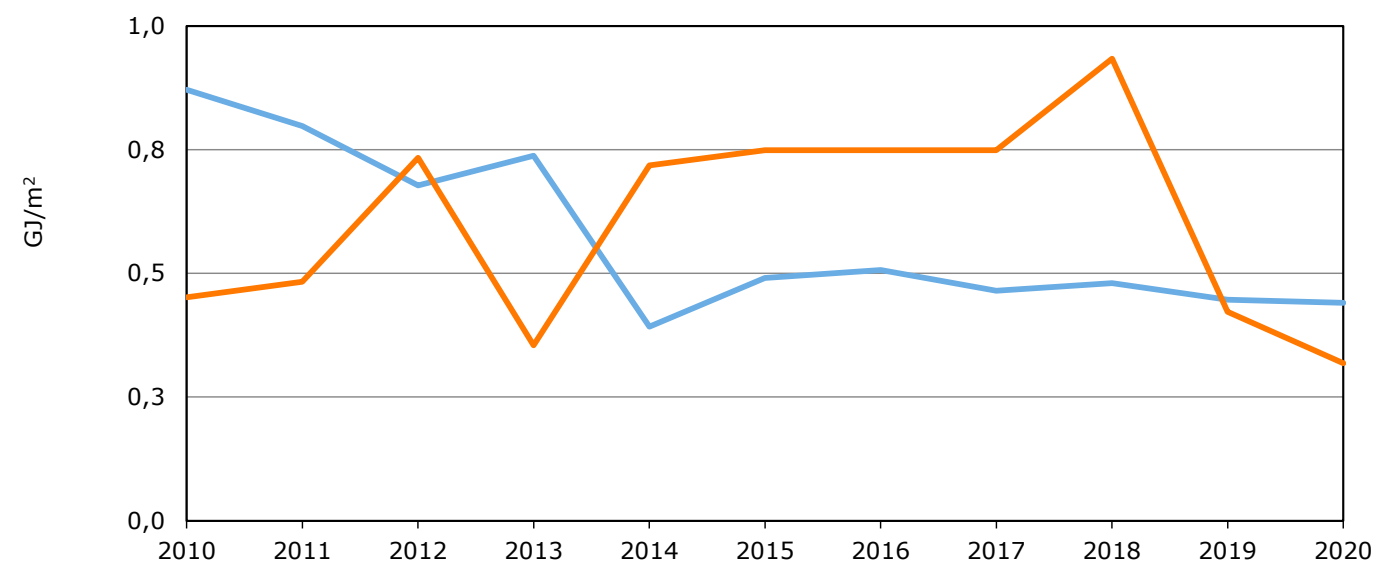

Aardwarmte Inkoop duurzame warmte

Figuur 3.7 Ontwikkeling van de gemiddelde warmtedekking van bij gebruik van aardwarmte en inkoop van lokale duurzame warmte in de glastuinbouw $\left(\mathrm{GJ} / \mathrm{m}^{2}\right) \mathrm{v}$ )

v) Cijfers 2020 voorlopig. 
Paradox energietransitie en rendabele inzet duurzame energiebronnen

Maximale benutting van duurzame bronnen heeft naast voordelen ook nadelen. Zo zal het potentieel areaal met duurzame warmte bij een beperkte warmtedekking eerder worden gerealiseerd. $\mathrm{Er}$ is dan veel areaal met gebruik van deze warmte, maar de mate waarin reductie van de $\mathrm{CO}_{2}$-emissie per $\mathrm{m}^{2}$ plaatsvindt is beperkt (figuur 3.8). De groei van het gebruik van duurzame warmte loopt dan tegen grenzen aan. Er zijn dan extra bronnen nodig om de dekking en de emissiereductie te verhogen. Als met extra bronnen de geleverde basislast vermogen verhoogd wordt naar middenlast is de gebruiksduur van deze extra bronnen korter. De bedrijfseconomische mogelijkheden voor deze extra bronnen zijn hierdoor meer beperkt. Ook kan de infrastructuur van bestaande installaties onvoldoende capaciteit hebben, waardoor bij nieuwe installaties ook nieuwe distributie-infrastructuur aangelegd moet worden. Dit is evenmin gunstig voor projectrendementen. Bekeken vanuit de totale energievoorziening op glastuinbouwbedrijven zal bij de introductie van extra warmtebronnen ook meer elektriciteit en $\mathrm{CO}_{2}$ ingekocht moeten worden, zodat verdere beperking van het gebruik van aardgaswkk mogelijk wordt. Hiernaast is het belangrijke stimuleringsinstrument vanuit de rijksoverheid, de SDE, gericht op kostenefficiëntie. Dit is gunstig voor het realiseren van individuele projecten met maximale benutting, oftewel een hoge bedrijfstijd, wat voor de glastuinbouw een lagere capaciteit en lagere dekking van de warmtevraag betekent. Het is ongunstig voor projecten met grotere vermogens per $\mathrm{m}^{2}$ kas, die een lagere bedrijfstijd en hogere warmtedekking hebben. Deze projecten zijn namelijk minder kosteneffectief. Stevige economische competitie met wkk-warmte en de insteek van stimuleringsmaatregelen (SDE) blijven hierom knelpunten bij het realiseren van $\mathrm{CO}_{2}$-emissiereductie zowel op sector- als bedrijfsniveau. 


\section{$4 \quad$ Warmtekrachtkoppeling, elektriciteitsbalans en inkoop van warmte}

\subsection{Inzet wkk heeft ook buiten de glastuinbouw effect}

Voor het invullen van de energievraag maakt de glastuinbouw gebruik van diverse energievoorzieningen. Hierbij is het gebruik van warmtekrachtkoppeling (wkk) een dominante factor. Hiernaast koopt de glastuinbouw elektriciteit en warmte in. Elektriciteit via het openbaar net, warmte van aanbieders van buiten de sector.

Door de inzet van wkk wordt op nationaal niveau primair brandstof bespaard en de $\mathrm{CO}_{2}$-emissie van Nederland verlaagd. Omdat de wkk's aardgas gebruiken verhoogt dit wel de $\mathrm{CO}_{2}$-emissie van de glastuinbouwsector (IPPC-methode). Door de inkoop van warmte wordt zowel de $\mathrm{CO}_{2}$-emissie van de glastuinbouw (IPCC-methode) als het primair brandstofverbruik - en dus de landelijke $\mathrm{CO}_{2}$-emissie verminderd. Dit komt doordat restwarmte van elektriciteitscentrales en industrie door de glastuinbouw wordt benut en hiervoor door de glastuinbouw zelf niet wordt gestookt.

De exploitatie van wkk door glastuinbouwbedrijven is al jaren van grote invloed op de elektriciteitsbalans van de glastuinbouw. Door inzet van wkk wordt minder elektriciteit ingekocht door de glastuinbouw en wordt elektriciteit op grote schaal verkocht aan derden.

In dit hoofdstuk komen de inzet van wkk in de glastuinbouw, de elektriciteitsbalans en de inkoop van warmte van derden aan bod. De duurzame varianten zijn behandeld in hoofdstuk 3 .

\subsection{Gelijke productie wkk, minder eigen toepassing en meer verkoop}

Wkk dominante bron voor warmte, licht en $\mathrm{CO}_{2}$

Warmtekrachtkoppeling (wkk) was ook in 2020 de dominante energievoorziening van de glastuinbouw. De inzet van wkk in de glastuinbouw betreft hoofdzakelijk aardgasmotoren in eigen beheer van de glastuinbouwbedrijven. De glastuinbouw produceert hiermee warmte en elektriciteit. De warmte die vrijkomt bij de elektriciteitsproductie met wkk wordt benut voor het verwarmen van de kassen (Smit en Van der Velden, 2008, Van der Velden en Smit, 2020). De elektriciteit wordt deels ingezet voor de eigen behoefte (vooral groeilicht) en voor een deel verkocht. De $\mathrm{CO}_{2}$ uit gereinigde rookgassen wordt op grote schaal benut voor de groei van het gewas. Naast de aardgas wkk's werd er in heel beperkte mate gebruik gemaakt van wkk's op biobrandstof.

\section{Vermogen en areaal stabiel}

Het totale elektrische vermogen van de wkk's van tuinders lag in 2019 en 2020 tussen de 2.500 en 2.600 MWe. In de periode 2011-2018 schommelde dit tussen de 2.200 en 2.500 MWe. De toename in 2019 en 2020 en de variatie in 2011-2018 hingen vooral samen met de ontwikkeling van het areaal glastuinbouw op basis van de LBT. Hiernaast zijn de energiemarkt en de beschikbare netwerkcapaciteit van invloed. Het areaal waar wkk in gebruik is, ligt al jaren op een niveau van ruim $60 \%$ van het totaal areaal glastuinbouw.

\section{Gebruik en verkoop elektriciteit verschoven}

Verkoop van elektriciteit vindt plaats bij vrijwel alle bedrijven met wkk. Door bedrijven met groeilicht wordt gemiddeld het merendeel zelf gebruikt, bij bedrijven zonder groeilicht wordt bijna alle elektriciteit verkocht. De hoeveelheid met wkk geproduceerde elektriciteit bedroeg in 202010,3 miljard kWh en was bijna gelijk aan 2019. In 2020 werd dit voor circa 40\% door de glastuinbouw zelf gebruikt. In 2019 was dit nog 44\%. De daling hangt grotendeels samen met keuzes van 
glastuinbouwbedrijven in het voorjaar bij het reageren op coronamaatregelen (incidenteel effect) en de toename van de kosten voor elektriciteitsinkoop door gestegen heffingen (ODE; structureel effect). Verkoop van elektriciteit nam, ondanks de grillen van de energiemarkt als gevolg van coronaomstandigheden, zowel in aandeel als totaal volume toe naar 60\% en 6,1 miljard kWh. Vanaf 2010 is geleidelijk een verschuiving opgetreden van verkoop naar eigen consumptie. Deze verschuiving is onlosmakelijk verbonden met de toename van het glastuinbouwareaal met belichting.

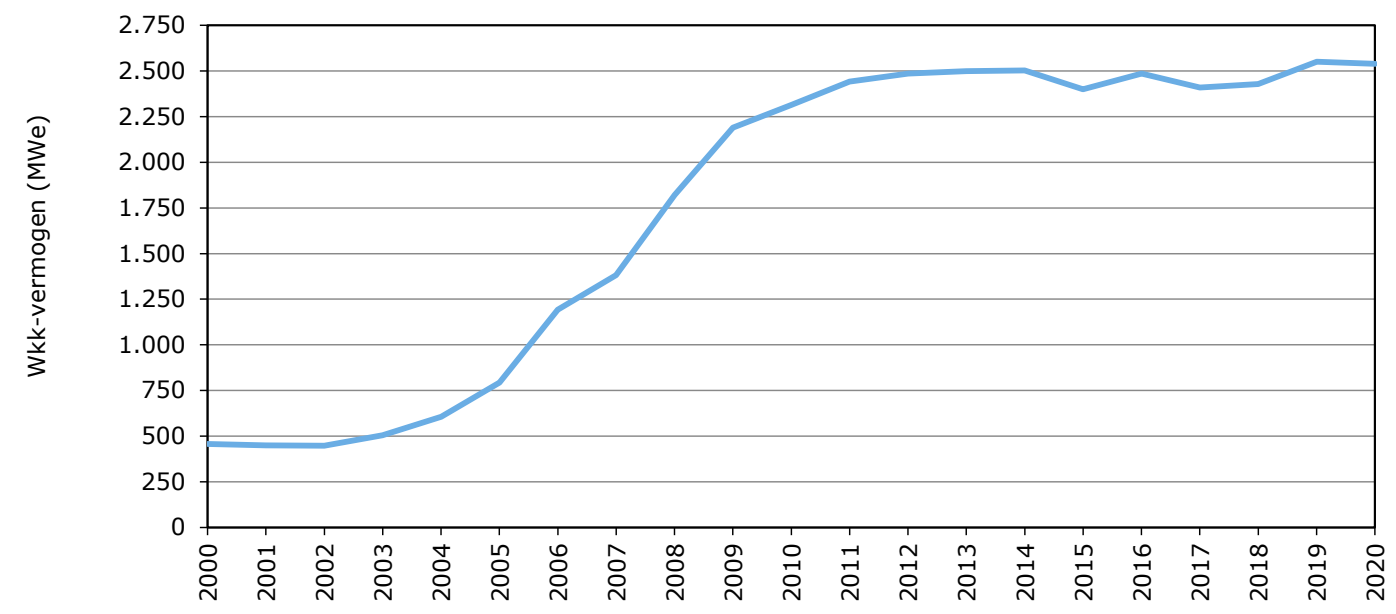

Figuur 4.1 Wkk-vermogen glastuinbouw $v$ )

Bron: CBS Landbouwtelling, bewerking Wageningen Economic Research.

v) Cijfer 2020 voorlopig.

Meer nieuwe wkk-installaties in 2020

Uit een inventarisatie door BlueTerra bij wkk-leveranciers is gebleken dat in 2019 circa 45 en in 2020 circa $70 \mathrm{MW}_{\text {el }}$ aan nieuw vermogen van aardgas wkk's op glastuinbouwbedrijven is geïnstalleerd (Hoek en Schlattman, 2020). Dit nieuwe wkk vermogen is grotendeels (circa 75\%) in bedrijf gesteld bij bedrijven met belichting. Voor de toekomst wordt in de verbinding van wkk met belichte teelt weinig verandering verwacht. Ten opzichte van het totaal vermogen was het vermogen van nieuwe installaties beperkt. Hiernaast worden bestaande installaties gereviseerd voor een verlengde levensduur.

\section{Wkk grootste bron van $\mathrm{CO}_{2}$}

De verkoop van elektriciteit vindt vooral overdag plaats. In deze uren is er minder inzet van groeilicht en de elektriciteitsprijs gemiddeld hoger. Bovendien past dit bij de behoefte aan $\mathrm{CO}_{2}$ die de gewassen juist bij daglicht hebben. De gereinigde rookgassen van de wkk's worden op grote schaal toegepast voor het doseren van $\mathrm{CO}_{2}$ (Van der Velden en Smit, 2019). Door het gebruik van wkk komt er per eenheid warmte meer $\mathrm{CO}_{2}$ beschikbaar in vergelijking met warmteproductie met de aardgasketel, omdat de wkk bijna de helft van het aardgas gebruikt voor de elektriciteitsproductie. Deze extra $\mathrm{CO}_{2}$ is gunstig voor de groei van het gewas en hiermee de ontwikkeling van de fysieke productie (paragraaf 2.2).

\section{Gebruiksduur wkk stabiel}

In 2020 lag de gemiddelde gebruiksduur (equivalente vollast-uren per jaar) van de wkk's tussen de 4.000 en 4.100 uur, vergelijkbaar met 2019. Vanaf 2016 heeft de gebruiksduur een toename laten zien, die samenhangt met toename van het areaal met belichting en gunstigere elektriciteitsprijzen voor verkoop. In 2020 werd in vergelijking met 2016 de wkk gemiddeld ruim 700 uur meer gebruikt. In de periode 2012-2016 was er juist een dalende trend (figuur 4.2), die vooral samenhing met onzekere prijzen voor tuinbouwproducten (minder belichting) en een ongunstigere spark spread (verschil in prijs tussen aardgas-input en elektriciteit-output). 


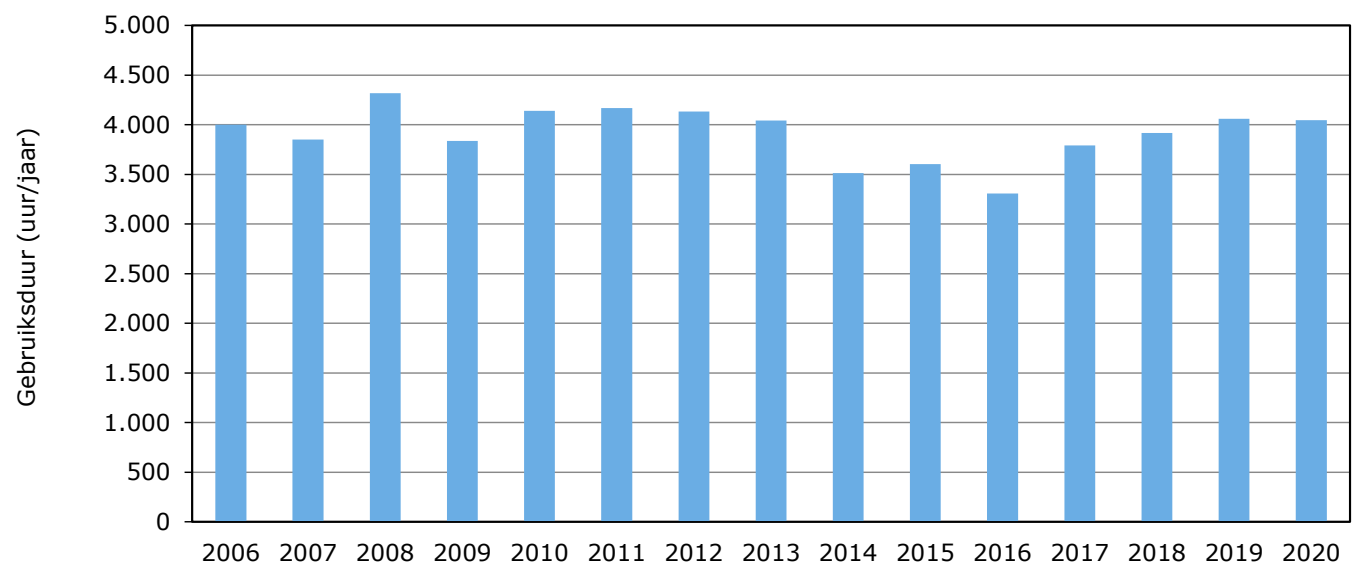

Figuur 4.2 Globale gemiddelde gebruiksduur wkk tuinders $v$ ) v) Cijfer 2020 voorlopig.

\subsection{Elektriciteitsbalans toont verschuiving van toepassing uit eigen productie naar verkoop}

De elektriciteitsbalans bestaat uit de vier elementen, namelijk productie, verkoop, inkoop en consumptie. In deze paragraaf worden deze elementen achtereenvolgens behandeld. De elektriciteitsbalans van 2020 is weergegeven in figuur 4.3 en de ontwikkeling over de jaren heen is opgenomen in figuur 4.4. De consumptie is niet gemeten, maar berekend als saldo van productie en inkoop vermindert met de verkoop en moet hierdoor als een globale indicatie worden gezien.

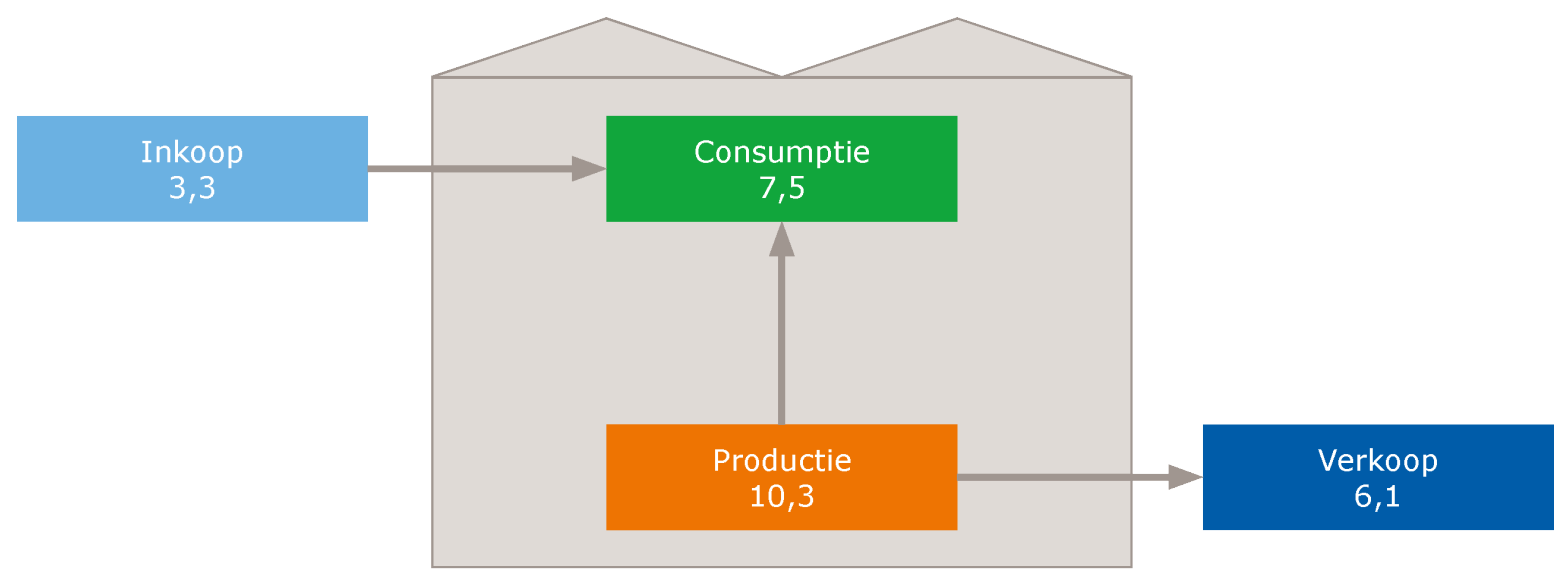

Figuur 4.3 Globale elektriciteitsbalans van de glastuinbouw in 2020 (TWh) v)

v) Cijfers voorlopig. 


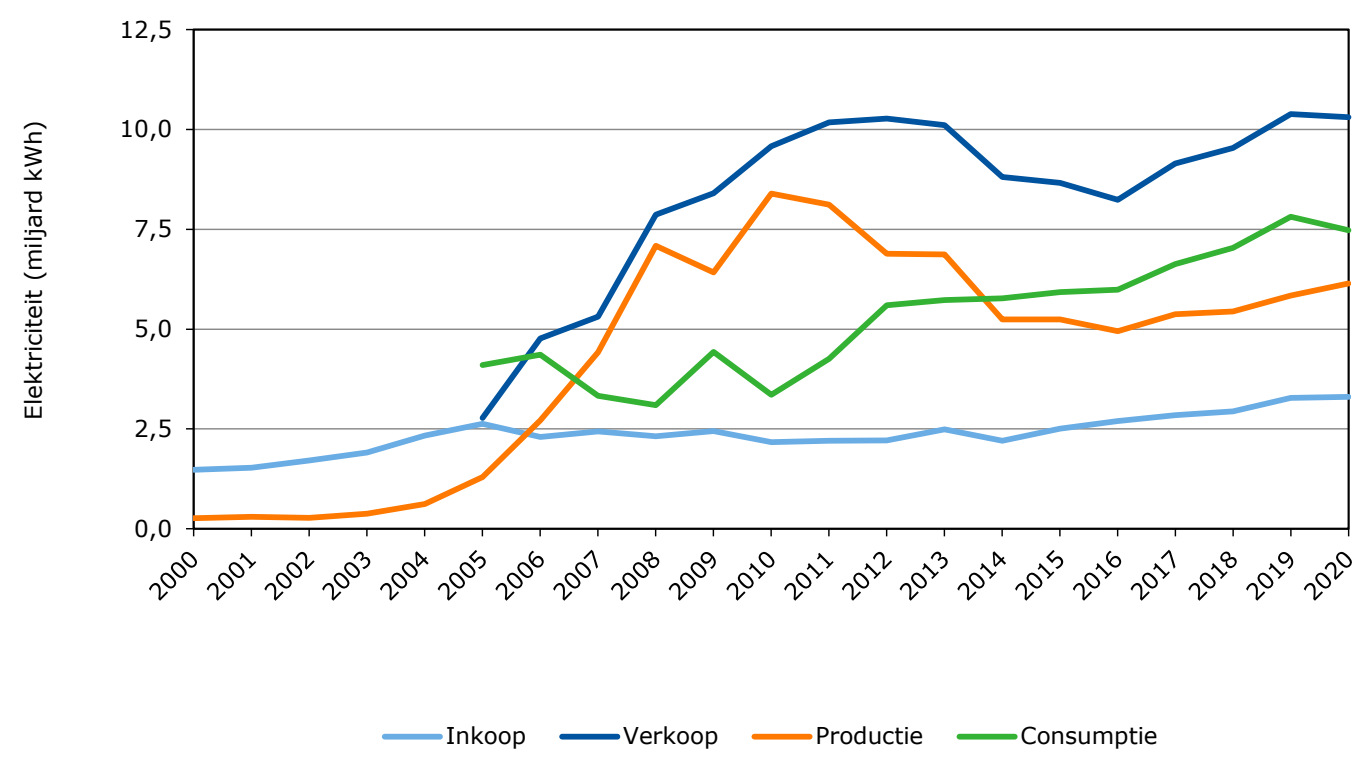

Figuur 4.4 Inkoop, verkoop, productie en consumptie van elektriciteit door de glastuinbouw v) v) De productie en de consumptie van voor 2005 zijn niet bekend; cijfers van 2020 zijn voorlopig.

\section{Elektriciteitsproductie stabiel}

De elektriciteitsproductie door de glastuinbouw groeide in de jaren 2011-2013 naar een niveau boven de 10 miljard kWh. Hierna trad een daling op van het totale wkk-vermogen in combinatie met een gemiddeld kortere gebruiksduur. Na 2016 groeide de productie weer. In 2019 en 2020 was de totale productie opnieuw meer dan 10 miljard kWh. Deze groei kwam door de toename van de gebruiksduur en het vermogen. De stijging van de gebruiksduur kwam door de toegenomen inzet van groeilicht en een gunstigere markt voor de verkoop van elektriciteit (verbeterde spark spread).

Naast de elektriciteitsproductie met aardgas-wkk produceerde de glastuinbouw ook duurzame elektriciteit. De hoeveelheid met bio-wkk en met zon-PV geproduceerde elektriciteit is minder dan 0,1 miljard kWh en dus relatief klein (hoofdstuk 3). De totale elektriciteitsproductie door de glastuinbouw voorzag in 2020 in ruim $9 \%$ van de totale Nederlandse elektriciteitsconsumptie van ruim 111 miljard kWh (CBS). De totale productie bedroeg in 2020 gemiddeld $102 \mathrm{kWh}$ per m² kas.

\section{Verkoop elektriciteit toegenomen}

Ook de verkoop liet vanaf 2016 een toename zien. Deze groei kwam door de verbeterde spark spread waardoor productie van elektriciteit voor de verkoop aantrekkelijker werd. De verkoop bedroeg in 2020 ruim 6,1 miljard $\mathrm{kWh}$, dit is gemiddeld $61 \mathrm{kWh}$ per $\mathrm{m}^{2}$ kas.

\section{Inkoop elektriciteit licht gegroeid}

De inkoop van elektriciteit liet in de periode 2014-2020 een stijgende lijn zien. In 2014 bedroeg de inkoop circa 2,2 en in 2020 is dit circa 3,3 miljard kWh. Deze ontwikkeling hangt samen met de toename van het areaal met groeilicht, de belichtingsintensiteit en de grenzen aan warmtebenutting bij gebruik van wkk. Per $\mathrm{m}^{2}$ kas werd in 2020 gemiddeld 33 kWh ingekocht. Door de reactie van glastuinbouwbedrijven in het voorjaar op coronamaatregelen (selectieve inzet van belichting) en de toegenomen kosten voor ingekochte elektriciteit door onder meer gestegen heffingen (ODE), nam de inkoop van elektriciteit in 2020 absoluut gezien beperkt toe en per $\mathrm{m}^{2}$ licht af. De eerste factor (reactie op corona) lijkt hierbij van incidentele aard, de tweede (ODE) van structurele aard.

\section{Netto-leverancier van elektriciteit}

Sinds 2006 is er jaarlijks meer elektriciteit verkocht dan ingekocht. Hierdoor is de glastuinbouw nettoleverancier van elektriciteit. Het saldo van verkoop minus inkoop steeg in 2020 naar circa 2,8 miljard kWh. Deze stijging van bijna 0,3 miljard kWh was het gevolg van de hiervoor beschreven daling van de inkoop en toename van de verkoop. 


\section{Elektriciteitsconsumptie licht gedaald}

De elektriciteitsconsumptie (som van productie en inkoop, vermindert met de verkoop) van de glastuinbouw sector daalde in 2020 voor het eerst sinds jaren. Vanaf 2012 groeide de elektriciteitsconsumptie, waarbij de groei vanaf 2016 sterker was. De daling in 2020 was vooral het gevolg van keuzes van glastuinbouwbedrijven in het voorjaar bij het anticiperen op coronamaatregelen (incidenteel) en de toegenomen kosten voor ingekochte elektriciteit (structureel). In 2020 bedroeg de totale elektriciteitsconsumptie van de glastuinbouw naar schatting 7,5 miljard $\mathrm{kWh}$; een daling van $4 \%$ ten opzichte van 2019 . Dit was bijna $7 \%$ van de nationale consumptie (CBS).

De toename van de elektriciteitsconsumptie komt vooral door de toename van de inzet van groeilicht en - in mindere mate - door de inzet van duurzame energievoorzieningen, verdere optimalisering van het kasklimaat, en toename van mechanisatie en automatisering. Naast deze intensivering van de elektriciteitsconsumptie wordt er ook elektriciteit bespaard. Er zijn efficiëntere installaties (LED) in gebruik genomen, selectieve belichtingsstrategieën worden toegepast, er worden slimme regelingen ingezet en er is schaalvergroting.

In de elektriciteitsconsumptie werd in 2020 voor circa $56 \%$ voorzien door eigen productie met wkk, de resterende $44 \%$ werd ingekocht. In de periode vanaf 2015 ligt de mate waarin de glastuinbouw in zijn eigen elektriciteitsvraag voorziet tussen de 55 en $60 \%$.

\section{Warmtebenutting wkk}

De vrijkomende warmte bij de elektriciteitsproductie met wkk wordt benut. Uit een eerdere studie (Smit en Van der Velden, 2008) is gebleken dat elektriciteitsproductie met een wkk bedrijfseconomisch niet uit kan zonder warmtebenutting. Ook bij de prijzen voor aardgas en elektriciteit van de laatste jaren is dat het geval.

Bedrijven met belichting plannen de draaiuren van de wkk in blokken voor belichting. Buiten deze blokken kan elektriciteit worden verkocht als de warmte kan worden benut en de opbrengst van de elektriciteit opweegt tegen de productiekosten. In de winter is er meer verkoop mogelijk omdat de warmtevraag dan groter is door de lagere buitentemperatuur. Tijdens elektriciteitsproductie met wkk kan $\mathrm{CO}_{2}$ uit de rookgassen worden gedoseerd voor de groei de gewassen (bij daglicht en tijdens belichting). Op het areaal met wkk werd in 2020 gemiddeld $24 \mathrm{~m}^{3}$ a.e. per $\mathrm{m}^{2}$ kas warmte benut uit de wkk's. De warmtedekking lag bij wkk daarmee iets hoger dan bij de inkoop van warmte.

\subsection{Inkoop van niet-duurzame warmte wederom gedaald}

De glastuinbouw kocht in 2020 warmte in van elektriciteitscentrales en industrie. Tot in 2018 werd er ook warmte ingekocht vanuit wkk's van energiebedrijven. In 2020 daalde de inkoop van nietduurzame warmte van leveranciers van buiten de glastuinbouw met meer dan $20 \%$ ten opzichte van 2019 naar 2,2 PJ (figuur 4.3). De daling kwam vooral door de hogere fractie duurzaam in de mix van de geleverde warmte; deze fractie telt mee bij duurzame energie (hoofdstuk 3 ). Hiernaast hebben de relatief hoge gemiddelde buitentemperatuur, afwegingen van glastuinbouwondernemers ingegeven door corona en het toegenomen wkk-gebruik door de glastuinbouwbedrijven een rol gespeeld.

De hoeveelheid ingekochte niet-duurzame warmte is $2,0 \%$ van het totale energiegebruik en $2,6 \%$ van de warmteconsumptie door de glastuinbouw. Het areaal waar deze warmte wordt toegepast was met circa 500 ha stabiel. Op het areaal waar warmte van elektriciteitscentrales en de industrie werd toegepast, werd in 2020 gemiddeld zo'n $22 \mathrm{~m}^{3}$ a.e. per $\mathrm{m}^{2}$ ingekochte warmte gebruikt.

De inkoop van niet-duurzame warmte neemt sinds het einde van de vorige eeuw af. Dit kwam vooral door het buiten gebruik stellen van meerdere regionale restwarmteprojecten. Vanaf 2014 liet de inkoop van warmte een lichte toename zien. Dit kwam door uitbreiding van het areaal kassen bij warmteprojecten. De laatste jaren neemt de inkoop af doordat een groeiend deel van de ingekochte warmte afkomstig is van biobrandstof en geothermie. 


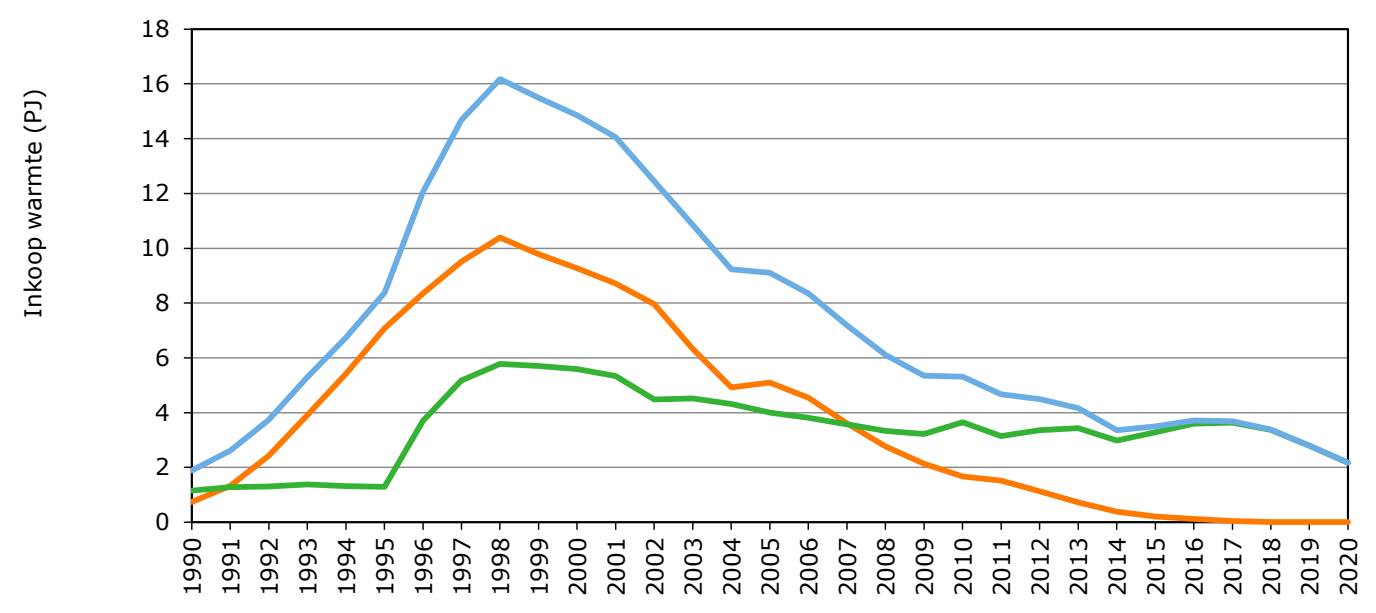

Wkk-warmte (derden) $\quad$ Restwarmte $\quad$ Totaal

Figuur 4.5 Inkoop van niet-duurzame warmte door de glastuinbouw $v$ )

v) Cijfers 2020 voorlopig.

\subsection{Effect inzet wkk en inkoop warmte op de $\mathrm{CO}_{2}$-emissie}

Effect inzet wkk op sector- en landelijk niveau verschillend

Het effect van wkk op de CO2-emissie kan op twee manieren worden bepaald. De ene insteek is de $\mathrm{CO}_{2}$-emissie c.q. het fossiele brandstofverbruik op sectorniveau (IPCC-methode). De andere insteek is de $\mathrm{CO}_{2}$-emissie op nationaal niveau c.q. het primair brandstofgebruik. Dit is relevant omdat de inzet van wkk door de glastuinbouw van invloed is op zowel $\mathrm{CO}_{2}$-emissie binnen als buiten de glastuinbouw. Door de glastuinbouw wordt aardgas ingekocht en elektriciteit verkocht. Hierdoor neemt de $\mathrm{CO}_{2}$ emissie van de glastuinbouw toe (IPCC-methode), terwijl dit bij elektriciteitscentrales afneemt. Het laatste effect is groter dan de toename van de $\mathrm{CO}_{2}$-emissie in de glastuinbouw, waardoor per saldo op nationaal niveau $\mathrm{CO}_{2}$-emissie (primair brandstof) wordt vermeden.

Op sectorniveau leidde de inzet van wkk in de glastuinbouw tot 2,8 Mton extra $\mathrm{CO}_{2}$-emissie. Buiten de glastuinbouw daalde de $\mathrm{CO}_{2}$-emissie door de inzet van wkk in de glastuinbouw met 4,4 Mton. Hierdoor is de netto $\mathrm{CO}_{2}$-emissiereductie op landelijk niveau 1,6 Mton. Dit komt overeen met een brandstofbesparing van 2,4 miljard $\mathrm{m}^{3}$ a.e.. Over de gehele periode 2014-2020 is er een beperkte toename van deze reductie. Ondanks dat in 2020 de elektriciteitsproductie met de wkk's in de glastuinbouw globaal gelijk was aan die in 2019, is de reductie van de $\mathrm{CO}_{2}$-emissie op nationaal niveau in 2020 lager. Dit komt door de verbeterde gemiddelde efficiëntie van de elektriciteitscentrales die gebruik maken van fossiele brandstof en zonder warmtelevering in geheel Nederland (de referentie, zie Protocol) waardoor er minder brandstof nodig is per eenheid geproduceerde elektriciteit. Hierdoor wordt de besparing aan primair brandstof door de wkk's in de glastuinbouw jaarlijks iets minder groot.

Emissiereductie door inkoop warmte gedaald

Door de hiervoor beschreven ontwikkelingen is de reductie van het primair brandstofverbruik door de inkoop van warmte van derden in 2020 opnieuw afgenomen. Deze bedroeg circa 66 miljoen $\mathrm{m}^{3}$ a.e. De inkoop van warmte droeg in 2020 voor bijna 1 procentpunt bij aan de verbetering van de energieefficiëntie. De reductie van de $\mathrm{CO}_{2}$-emissie van de glastuinbouw door inkoop van warmte was in 2020 met 0,12 Mton hoger dan de reductie op nationaal niveau 0,09 Mton (tabel 4.1). Dit komt door de extra uitstoot bij de centrales en de industrie die samenhangt met de productie van de geleverde warmte. Dit laatste telt mee op nationaal niveau (primair brandstof) en niet bij de glastuinbouw (IPCC-methode). 
Tabel 4.1 Effect inzet wkk en inkoop warmte op de $\mathrm{CO}_{2}$-emissie in $2020 \mathrm{v}$ )

\begin{tabular}{lcc} 
Bron & Sectoraal / IPPC methode & National / Primair Brandstof methode \\
\hline Wkk-tuinders & Mton & $-1,57$ \\
\hline Inkoop warmte & $+2,78$ & $-0,09$ \\
\hline Totaal & $-0,12$ & $\mathbf{- 1 , 6 6}$
\end{tabular}

v) Cijfers 2020 voorlopig. 


\section{$5 \quad$ Energievoorzieningen zonder $\mathrm{CO}_{2}-$ emissie voor de glastuinbouw}

\subsection{Emissiereductie en energietransitie langs twee hoofdlijnen}

Het verlagen van de $\mathrm{CO}_{2}$-emissie en de energietransitie verlopen via twee hoofdlijnen. De ene hoofdlijn is het verlagen van de energievraag door energiebesparing. De andere hoofdlijn is het invullen van de energievraag met energievoorzieningen zonder $\mathrm{CO}_{2}$-emissie.

In de Energiemonitor wordt de energiebesparing niet gekwantificeerd. Energiebesparing is het resultaat van bedrijfsprocessen achter de energiemeters (paragraaf 2.4 ).

Voor de energievoorziening zonder $\mathrm{CO}_{2}$-emissie wordt gewerkt aan het vergroten van de inzet van duurzame energiebronnen door de glastuinbouw en het aankopen van niet-duurzame warmte en elektriciteit van partijen van buiten de sector.

Het effect van energievoorzieningen zonder $\mathrm{CO}_{2}$-emissie is behandeld in hoofdstuk 2 en het gebruik van duurzame energie en de inkoop van niet-duurzame energie in de hoofdstukken 3 en 4 . In dit hoofdstuk wordt een overzicht gegeven van de ontwikkeling van energievoorzieningen zonder $\mathrm{CO}_{2}-$ emissie.

\subsection{Aandeel energievoorzieningen zonder $\mathrm{CO}_{2}$-emissie gegroeid en beheer aan het verschuiven}

Energievoorzieningen zonder $\mathrm{CO}_{2}$-emissie voor de glastuinbouwsector bestaan uit de inzet van duurzame energie en de inkoop van niet-duurzame warmte en elektriciteit van partijen van buiten de sector. Bij inkoop van warmte en elektriciteit is de bron per definitie in exploitatie bij partijen buiten de glastuinbouw en is er een leverings-/afnameovereenkomst tussen afnemer en leverancier.

Bij de inzet van duurzame energie is de exploitatie anders. Veel van de duurzame energiebronnen ingezet in de glastuinbouw zijn in beheer bij de glastuinbouwbedrijven zelf. De laatste jaren is een trend gaande waarbij projecten voor de inzet van duurzame energie steeds vaker met partners van buiten de sector gerealiseerd worden en waarbij deze partners ook de exploitatie in handen hebben. Dit komt doordat duurzame energieprojecten groter worden van omvang en complex en risicovol zijn. Partners en tuinders gaan hierbij langjarige leverings- en afnameovereenkomsten aan.

De duurzame energiebronnen aardwarmte en installaties op biobrandstof komen zowel voor in exploitatie bij de tuinders als bij derden. Het totaal aan toegepaste duurzame warmte met als oorsprong aardwarmte bedroeg in 2020 6,1 PJ. Voor biobrandstof was dit 3,7 PJ. De herkomst van de duurzame elektriciteit is voor de Energiemonitor niet herleidbaar.

Over de periode 2010-2020 is het aandeel van energievoorzieningen zonder $\mathrm{CO}_{2}$-emissie voor de glastuinbouw bijna verdubbeld, van 11,7\% in 2010 naar 22,5\% in 2020. Deze groei kwam vooral door de groei van de inzet van duurzame energie en de groei van de inkoop elektriciteit. Afname van de inkoop niet-duurzame warmte dempte de groei (tabel 5.1). 
Tabel 5.1 Energievoorzieningen zonder $\mathrm{CO}_{2}$-emissie voor de glastuinbouwsector naar typering en bron in $2020 \mathrm{v}$ )

\begin{tabular}{|c|c|c|c|c|c|}
\hline \multirow[t]{2}{*}{ Typering } & \multicolumn{2}{|c|}{ Totaal } & Bron & \multicolumn{2}{|c|}{ subtotaal } \\
\hline & PJ & TWh & - & PJ & TWh \\
\hline \multirow[t]{5}{*}{ Duurzame energie } & 10,6 & 0,2 & Aardwarmte & 4,2 & \\
\hline & & & Zonne-energie & 0,8 & $<0,1$ \\
\hline & & & Inkoop warmte & 4,1 & \\
\hline & & & waarvan biobrandstof & 2,2 & \\
\hline & & & Inkoop elektriciteit & & 0,2 \\
\hline Inkoop niet-duurzame warmte & 2,2 & & Inkoop warmte & 2,2 & \\
\hline Inkoop niet-duurzame elektriciteit & & 3,1 & Inkoop elektriciteit & & 3,1 \\
\hline
\end{tabular}

v) Cijfers voorlopig.

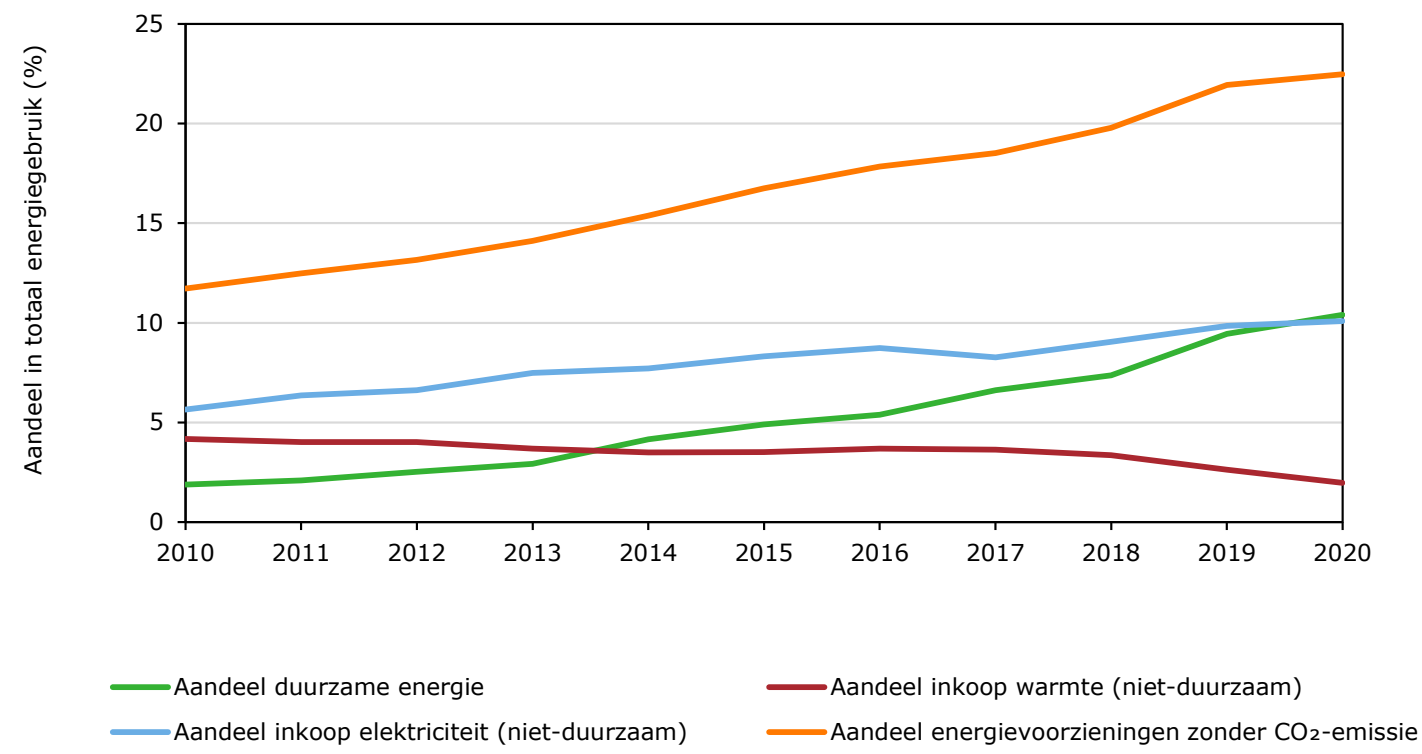

Figuur 5.1 Ontwikkeling van het aandeel van energievoorzieningen zonder $\mathrm{CO}_{2}$-emissie voor de glastuinbouwsector 2010-2020 v)

v) Cijfers 2020 voorlopig.

\subsection{Inkoop $\mathrm{CO}_{2}$ licht gedaald door leveringsonderbreking}

Naast dat de glastuinbouw met het gebruik van fossiele brandstoffen $\mathrm{CO}_{2}$ uitstoot, wordt $\mathrm{CO}_{2}$ ook gebruikt als meststof voor een optimale productie van de gewassen. Deze $\mathrm{CO}_{2}$ is in de huidige situatie vooral afkomstig van de rookgassen van aardgasgestookte wkk's en ketels. Bij het vervangen van fossiele brandstof door energiebronnen zonder $\mathrm{CO}_{2}$-emissie, valt de $\mathrm{CO}_{2}$-voorziening en daarmee een essentiële productiefactor weg. De overgang naar duurzame energie en inkoop van warmte en elektriciteit kan daardoor niet zonder het gebruik van externe $\mathrm{CO}_{2}$ (Van der Velden en Smit, 2019). Hiernaast kan de inzet van externe $\mathrm{CO}_{2}$ de zomerstook verminderen en wordt externe $\mathrm{CO}_{2}$ gebruikt door glastuinbouwbedrijven die het mogelijke risico van schadelijke elementen in rookgassen te groot achten. Met zomerstook wordt de $\mathrm{CO}_{2}$-productie uit aardgas zonder warmtebenutting bedoeld en het vermijden hiervan is energiebesparing.

In 2020 werd zo'n 0,67 Mton $\mathrm{CO}_{2}$ extern ingekocht; ruim 5\% minder dan in 2019. Deze daling kan voor het grootste deel worden toegeschreven aan een tijdelijke leveringsonderbreking bij de grootste 
bron van externe $\mathrm{CO}_{2}$. De inkoop per as liet wel groei zien mede door groei van de behoefte bij de inzet van duurzame warmte in gebieden buiten het leveringsgebied van centrale $\mathrm{CO}_{2}$. Hiernaast kan terughoudendheid ten aanzien van aankoop van externe $\mathrm{CO}_{2}$ door onzekere inkomsten door coronamaatregelen in het tweede kwartaal van 2020 een rol hebben gespeeld.

De gemiddelde toepassing van externe $\mathrm{CO}_{2}$ op het totale areaal in de sector bedroeg in $20206,3 \mathrm{~kg}$ per $\mathrm{m}^{2}$. Bezien over een langere periode is er sprake van toenemende vraag naar externe $\mathrm{CO}_{2}$.

Bedrijven kopen meer $\mathrm{CO}_{2}$ in voor productie-optimalisatie en externe $\mathrm{CO}_{2}$ is nodig in combinatie met de inzet van energievoorzieningen zonder $\mathrm{CO}_{2}$-emissie.

Circa een derde van het areaal met duurzame energie was te vinden in de gebieden met centrale levering van externe $\mathrm{CO}_{2}$. Voor de verdere ontwikkeling van het gebruik van duurzame energie en de inkoop van warmte en elektriciteit is toename van de hoeveelheid beschikbare externe $\mathrm{CO}_{2}$ en verhoging van de leveringszekerheid van groot belang. Externe $\mathrm{CO}_{2}$ komt beschikbaar als bijproduct van industriële processen. Onderscheid is te maken tussen $\mathrm{CO}_{2}$ van fossiele en van biogene oorsprong. $\mathrm{Er}$ is verder onderscheid te maken tussen centrale en lokale levering (figuur 5.2). Het gebruik van externe $\mathrm{CO}_{2}$ in de glastuinbouw betreft grotendeels centrale levering van zuivere $\mathrm{CO}_{2}$ dat wordt gedistribueerd via een leidingnetwerk. Lokale levering betreft hoofdzakelijk levering van zuivere $\mathrm{CO}_{2}$ per as en is de laatste jaren vooral in gebieden zonder leidingnetwerk groeiende.

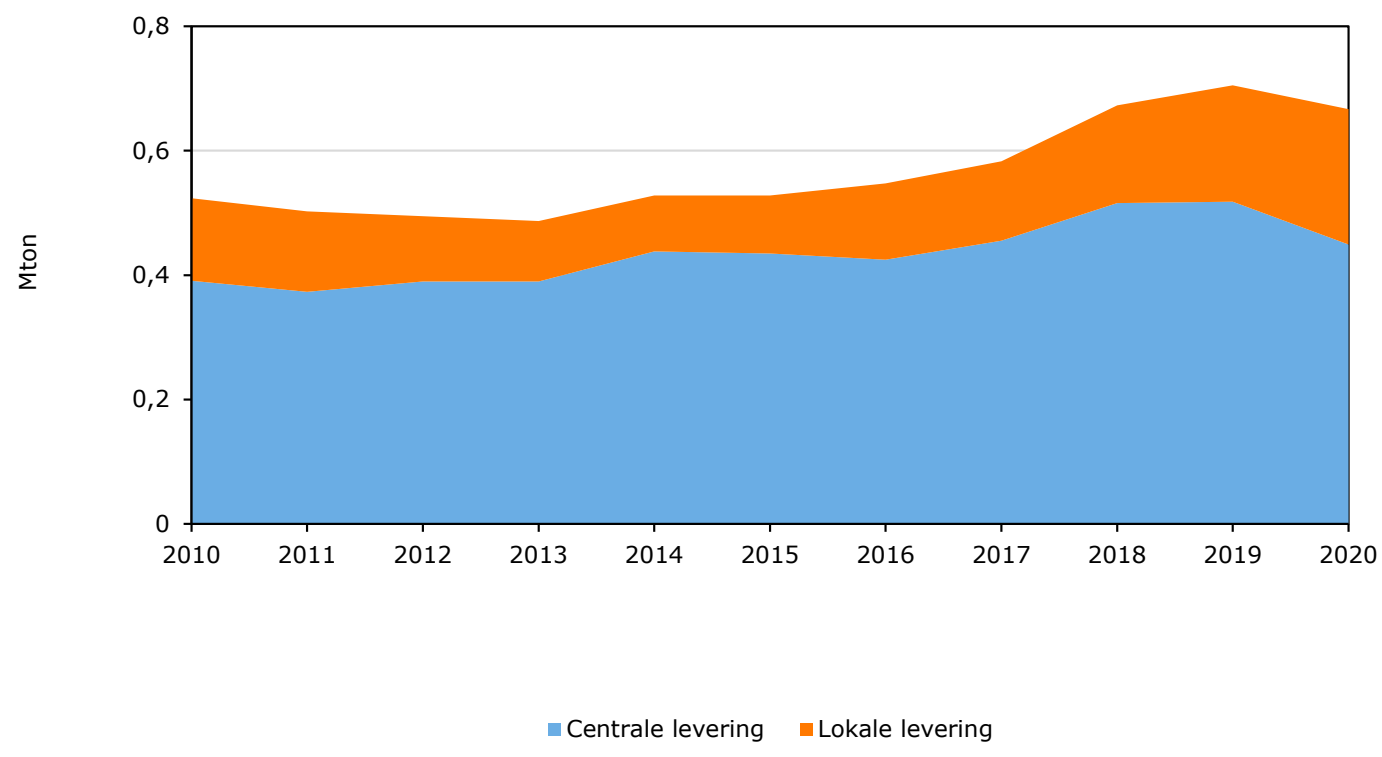

Figuur 5.2 Ontwikkeling inkoop externe $\mathrm{CO}_{2}$ (centraal en lokaal) door de Nederlandse glastuinbouw (Mton) $v$ )

v) Cijfers 2020 voorlopig. 


\section{Conclusies}

Stijging $\mathrm{CO}_{2}$-emissie in 2020 voortgezet

In 2020 steeg de totale $\mathrm{CO}_{2}$-emissie van de glastuinbouw met 0,2 Mton naar 6,1 Mton. De toename van 0,2 Mton was gelijk aan de stijging in 2019. De totale $\mathrm{CO}_{2}$-emissie lag in $202011 \%$ onder de emissie van 1990. De $\mathrm{CO}_{2}$-emissie van de teelt (exclusief verkoop elektriciteit) bedroeg in 2020 4,4 Mton en lag 35\% onder het niveau van 1990.

De stijging van de totale $\mathrm{CO}_{2}$-emissie in de periode $2019 \mathrm{t} / \mathrm{m} 2020$ volgde op een daling in de periode 2010 t/m 2014 en stabilisatie in de periode 2015 t/m 2018. De stijging 2019 en 2020 kwam door aanpassing van het areaal in de Landbouwtelling, stijging van de elektriciteitsverkoop, daling van de inkoop van niet-duurzame warmte en toename van het energiegebruik per $\mathrm{m}^{2}$. Dit werd deels gecompenseerd door de groei van duurzame energie en de stijging van de elektriciteitsinkoop. Uit de toename van het energiegebruik per $\mathrm{m}^{2}$ blijkt dat het effect van intensivering in $2019 \mathrm{t} / \mathrm{m} 2020$ op de $\mathrm{CO}_{2}$-emissie groter was dan het gezamenlijke effect van extensivering en energiebesparing.

$\mathrm{CO}_{2}$-emissie teelt per $\mathrm{m}^{2}$ na temperatuurcorrectie in 2020 minder gestegen dan totale $\mathrm{CO}_{2}$-emissie De $\mathrm{CO}_{2}$-emissie van de teelt per $\mathrm{m}^{2}$ na correctie voor de buitentemperatuur nam in 2020 met 0,3 kg toe naar $45,7 \mathrm{~kg} \mathrm{CO}_{2}$ per $\mathrm{m}^{2}$. Het is hiermee $40 \%$ lager dan in 1990 . Ook is de stijging $(+0,7 \%)$ lager dan de toename van de totale $\mathrm{CO}_{2}$-emissie $(+3,3 \%)$. Deze indicator is onafhankelijk van de externe factoren buitentemperatuur, het areaal en de verkoop van elektriciteit en geeft inzicht in wat de glastuinbouwsector $\mathrm{CO}_{2}$-emissiereductie realiseert.

\section{Energie-efficiëntie verslechterd}

De energie-efficiëntie index van de productieglastuinbouw verslechterde in 2020 met 2 procentpunten naar $49 \%$ ten opzichte van 1990 . Het primair brandstofverbruik per $\mathrm{m}^{2}$ bleef gelijk en de fysieke productie per $\mathrm{m}^{2}$ daalde. De fysieke productie daalde vooral door de aanpassing van het areaal in de Landbouwtelling. De trend van het nastreven van een hogere waarde per eenheid product en anticipatie op effecten van corona speelden ook een rol.

Inzet en aandeel duurzame energie groeit door

Het aandeel duurzame energie in de glastuinbouw nam in 2020 toe met bijna 1 procentpunt naar 10,4\%. De totale hoeveelheid toegepaste duurzame energie groeide van 10,0 naar 11,5 PJ.

Toepassing van aardwarmte (37\%) en inkoop van duurzame warmte van partijen van buiten de sector (36\%) zijn met bijna driekwart van de totale hoeveelheid duurzame energie de belangrijkste bronnen. In 2020 namen inkoop van duurzame warmte, inzet van biobrandstof en zonne-elektriciteit het sterkst toe. De inkoop van duurzame elektriciteit nam net als in 2018 en 2019 af.

De toegepaste duurzame energie bestond voor 93\% uit warmte en voor $7 \%$ uit elektriciteit.

Steeds vaker worden duurzame energieprojecten door glastuinbouwbedrijven samen ontwikkeld en worden partners van buiten de sector steeds belangrijker. Met de inzet van duurzame energie werd in de glastuinbouw in 2020 0,6 Mton $\mathrm{CO}_{2}$-emissie vermeden. Het positieve effect op de energieefficiëntie index was 5 procentpunten.

Totaal energiegebruik gestegen, energiegebruik per $\mathrm{m}^{2}$ stabiel en energiekosten gedaald Het totaal energiegebruik steeg in 2020 naar 110 PJ. Deze stijging kwam vooral door toename van het areaal in de Landbouwtelling. Het energiegebruik per $\mathrm{m}^{2}$ was in 2020 met $1,1 \mathrm{GJ} / \mathrm{m}^{2}$ ten opzichte 2019 stabiel. Het aandeel warmte bedroeg 76\% en het aandeel elektriciteit $24 \%$.

De netto-energiekosten per $\mathrm{m}^{2}$ zijn in 2020 gedaald naar gemiddeld $€ 6,50$ per $\mathrm{m}^{2}$. Zowel de kosten voor inkoop als de opbrengsten van verkoop waren lager. De daling bij de inkoop was sterker dan de daling bij de verkoop, waardoor de netto-energiekosten daalden. Door de effecten van coronamaatregelen op de productie en afzet van glastuinbouwproducten en de energiemarkt is 2020 
ook een grillig jaar gebleken in energievraag en energieprijzen (incidenteel effect). Ook kregen vooral bedrijven met belichting te maken met een hogere ODE-heffing, wat vooral glastuinbouwbedrijven met belichting raakte (structureel effect).

Elektriciteitsbalans en inzet wkk verschoven

De productie van elektriciteit was in 2020 met ruim 10 TWh (miljard kWh) globaal gelijk aan 2019. De inkoop (3,3 TWh) en verkoop (6,1 TWh) stegen. Waar de stijging van de inkoop met 0,1 TWh beperkt was, steeg de verkoop sterker met 0,3 TWh. De elektriciteitsconsumptie daalde naar 7,5 TWh. Deze ontwikkelingen kwamen hoofdzakelijk voort uit een gunstigere sparkspread. Hiernaast speelden de stijging van de ODE-heffing op inkoop van elektriciteit (structureel) en keuzes van ondernemers in het voorjaar van 2020 bij het anticiperen op coronamaatregelen (incidenteel) een rol.

Door de inzet van wkk's in de glastuinbouw lag in 2020 de $\mathrm{CO}_{2}$-emissie van de glastuinbouw 2,8 Mton hoger, maar werd er landelijk 4,4 Mton $\mathrm{CO}_{2}$-emissie voorkomen; een netto-reductie van 1,6 Mton. De inkoop van niet-duurzame warmte van partijen van buiten de sector nam wederom af; van 88 miljoen $\mathrm{m}^{3}$ a.e. in 2019 naar 69 miljoen $\mathrm{m}^{3}$ a.e. in 2020. Het reducerend effect van de inkoop van niet-duurzame warmte was op de $\mathrm{CO}_{2}$-emissie was in 2020 ruim 0,1 Mton.

Aandeel energievoorzieningen zonder $\mathrm{CO}_{2}$-emissie in tien jaar verdubbeld

Aardgas is nog steeds de dominante energiebron voor de glastuinbouw. Echter, het aandeel van energievoorzieningen zonder $\mathrm{CO}_{2}$-emissie groeit gestaag. Sinds 2010 is dit aandeel bijna verdubbeld naar $22,5 \%$. Iets meer dan helft van de hoeveelheid energie uit bronnen zonder $\mathrm{CO}_{2}$-emissie betrof warmte, de rest elektriciteit. Bij het deel warmte wordt circa de helft door de glastuinbouw zelf opgewekt en de andere helft ingekocht bij partijen van buiten de sector. Het deel elektriciteit wordt hoofdzakelijk ingekocht.

Inkoop externe $\mathrm{CO}_{2}$ gedaald

In 2020 werd 0,67 Mton externe $\mathrm{CO}_{2}$ aangekocht, een daling van 0,04 Mton ten opzichte van 2019 en de eerste daling sinds 2013. Deze daling kwam hoofdzakelijk door verminderde beschikbaarheid door een leveringsonderbreking bij de grootste bron. 


\section{Bronnen en literatuur}

Meerjarenafspraak Energietransitie Glastuinbouw 2014-2020, Den Haag, 2014.

Convenant $\mathrm{CO}_{2}$ emissieruimte binnen het $\mathrm{CO}_{2}$ sectorsysteem glastuinbouw voor de periode 20132020. 2011.

Klimaatakkoord, Den Haag 28 juni 2019; paragraaf 4.6 Glastuinbouw.

Brief van de Staatssecretaris van Economische Zaken, aan de voorzitter van de Tweede Kamer betreffende Evaluatie $\mathrm{CO}_{2}$-sturing in de glastuinbouw, dd. 6 juli 2017.

Brief van de Minister van Landbouw, Natuur en Voedselkwaliteit, aan de voorzitter van de Tweede Kamer betreffende Glastuinbouw en rapport Effecten van actuele ontwikkelingen op prognoses $\mathrm{CO}_{2}$-emissie glastuinbouw, dd. 15 juli 2021.

Hoek, T. en S. Schlatmann, Inventarisatie nieuwe gasmotoren. Notitie. BlueTerra, 2021.

Smit, P.X. en N.J.A. van der Velden, Energiebenutting warmtekrachtkoppeling in de Nederlandse glastuinbouw. Rapport 2008-019. LEI Wageningen UR, Den Haag, 2008.

Smit, P.X. en N.J.A. van der Velden, Protocol Energiemonitor Glastuinbouw; Versie tot en met 2020. Nota 2021-127a Wageningen Economic Research, 2021 (in voorbereiding).

Velden, N.J.A. van der en P.X. Smit, Groei elektriciteitsconsumptie glastuinbouw; Hoe verder?. Rapport 2013-022. LEI Wageningen UR, 2013.

Velden, N.J.A. van der en P.X. Smit, Effect intensivering, extensivering en energiebesparing op $\mathrm{CO}_{2}-$ emissie Nederlandse glastuinbouw. Rapport 2017-060. Wageningen Economic Research, 2017

Velden, N.J.A. van der, P.X. Smit en R.W van der Meer, Tariefstijging ODE inkoop elektriciteit: effecten kosten en $\mathrm{CO}_{2}$-emissie glastuinbouw. Rapport 2020-044. Wageningen Economic Research, 2020.

Velden, N.J.A. van der en P.X. Smit, Raming $\mathrm{CO}_{2}$-emissie glastuinbouw 2020. Rapport 2020-110. Wageningen Economic Research, 2020.

Velden, N.J.A. van der en P.X. Smit, Effecten van actuele ontwikkelingen op prognoses $\mathrm{CO}_{2}$-emissie glastuinbouw 2030. Rapport 2021-071. Wageningen Economic Research, 2021.

WKK Barometer, Marktpositie wkk voorjaar 2021, BlueTerra, 2021.

www.cbs.nl

www.kasalsenergiebron.nl 


\section{Bijlage 1 Definities, methode en bronnen}

\section{B1.1 Definities}

Protocol

De definities, methodiek en bronnen zijn vastgelegd in het Protocol Energiemonitor Glastuinbouw (Van der Velden en Smit, 2019) en worden in deze bijlage op hoofdlijnen toegelicht.

\section{Definities van indicatoren}

De energie-efficiëntie is het primair brandstofverbruik per eenheid product van de productieglastuinbouw, uitgedrukt in procenten van het niveau in het basisjaar.

De $\mathrm{CO}_{2}$-emissie wordt uitgedrukt in Mton per jaar en wordt bepaald volgens de IPCC-methode en heeft betrekking op de gehele glastuinbouwsector. Onderscheid wordt gemaakt naar de totale $\mathrm{CO}_{2}$-emissie van de sector en de $\mathrm{CO}_{2}$-emissie van de teelt (exclusief verkoop elektriciteit uit aardgasgestookte wkk).

Het aandeel duurzame energie is het quotiënt van de gebruikte hoeveelheid duurzame energie en het totale netto-energiegebruik (inkoop minus verkoop) in de gehele glastuinbouw, uitgedrukt in procenten.

De definities van de indicatoren verschillen ten aanzien van het areaal glas en het begrip energie.

\section{Areaal}

De glastuinbouw omvat het areaal productieglastuinbouw en het areaal uitgangsmateriaal (figuur B1.1). De productieglastuinbouw bestaat uit de subsectoren groente, bloemen en potplanten. Het uitgangsmateriaal betreft de teelt van zaden en stek en de opkweek van jonge planten.

Uitgangsmateriaal wordt gezien als toelevering (binnen en buiten de glastuinbouw) en niet als primaire productie. Daarom blijft het areaal met uitgangsmateriaal buiten beschouwing bij de energieefficiëntie. De $\mathrm{CO}_{2}$-emissie heeft betrekking op de gehele glastuinbouw, inclusief het areaal uitgangsmateriaal.

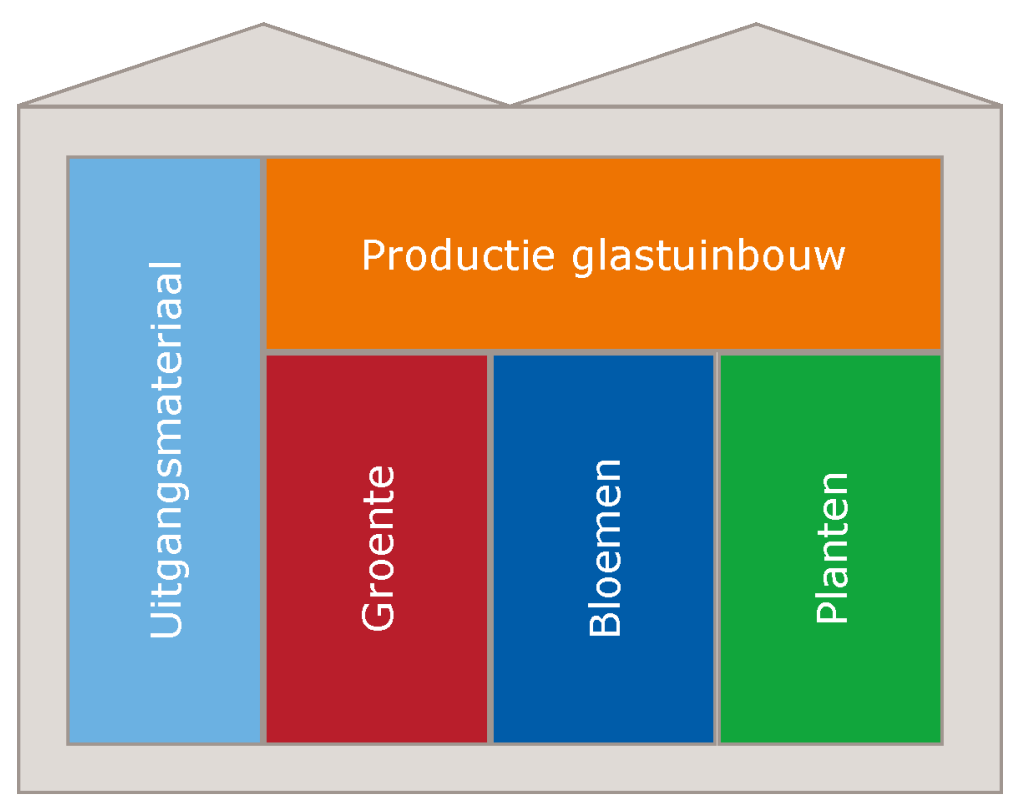

Figuur B1.1 Schematische weergave areaal glastuinbouw en productieglastuinbouw 


\section{Energie}

Het energiegebruik in de glastuinbouw omvat meerdere soorten (figuur B1.2). Aardgas, overig fossiel, warmte en elektriciteit worden ingekocht en elektriciteit en warmte verkocht. Duurzame energie wordt ingekocht, geproduceerd en verkocht. Dit alles is op verschillende wijzen te sommeren.

Sommatie van de afzonderlijke energiesoorten op basis van energie-inhoud resulteert in het kengetal totaal energiegebruik. De verkoop van energie wordt hierbij in mindering gebracht.

Voor het primair brandstofverbruik wordt de hoeveelheid fossiele brandstof bepaald die nodig is voor de productie van de afzonderlijke energiesoorten. Aardgas en overige fossiele brandstoffen zijn primaire brandstoffen. De inkoop van elektriciteit wordt herleid tot de hoeveelheid brandstof die daarvoor nodig is in een gemiddelde Nederlandse elektriciteitscentrale zonder warmtelevering. Voor de verkoop van elektriciteit geldt hetzelfde, maar dit wordt in mindering gebracht. De ingekochte warmte komt van elektriciteitscentrales (restwarmte), industrie en van energiebedrijven. Door de gecombineerde productie van elektriciteit en warmte ligt de elektriciteitsproductie lager. Voor de geleverde warmte wordt de extra hoeveelheid brandstof berekend die nodig is om de derving van de elektriciteitsproductie te compenseren.

De $\mathrm{CO}_{2}$-emissie wordt bepaald op basis van de IPCC-methode. Hierbij wordt alleen de werkelijk verstookte fossiele brandstof op glastuinbouwbedrijven in beschouwing genomen. Onderscheid wordt gemaakt naar de totale $\mathrm{CO}_{2}$-emissie en de $\mathrm{CO}_{2}$-emissie van de teelt. De totale $\mathrm{CO}_{2}$-emissie heeft betrekking op alle fossiele brandstoffen, inclusief de productie van elektriciteit op de glastuinbouwbedrijven. De $\mathrm{CO}_{2}$-emissie van de teelt is de totale $\mathrm{CO}_{2}$-emissie, verminderd met de emissie die gerelateerd is aan door de glastuinbouw verkochte elektriciteit, geproduceerd met aardgasgestookte wkk.

Het primair brandstofverbruik is de grondslag voor de energie-efficiëntie. De $\mathrm{CO}_{2}$-emissie wordt bepaald op basis van het werkelijke gebruik van fossiele brandstoffen (IPCC-methode).

Het totale energiegebruik wordt gebruikt voor het bepalen van het aandeel duurzame energie. Netto wil zeggen inkoop minus verkoop.

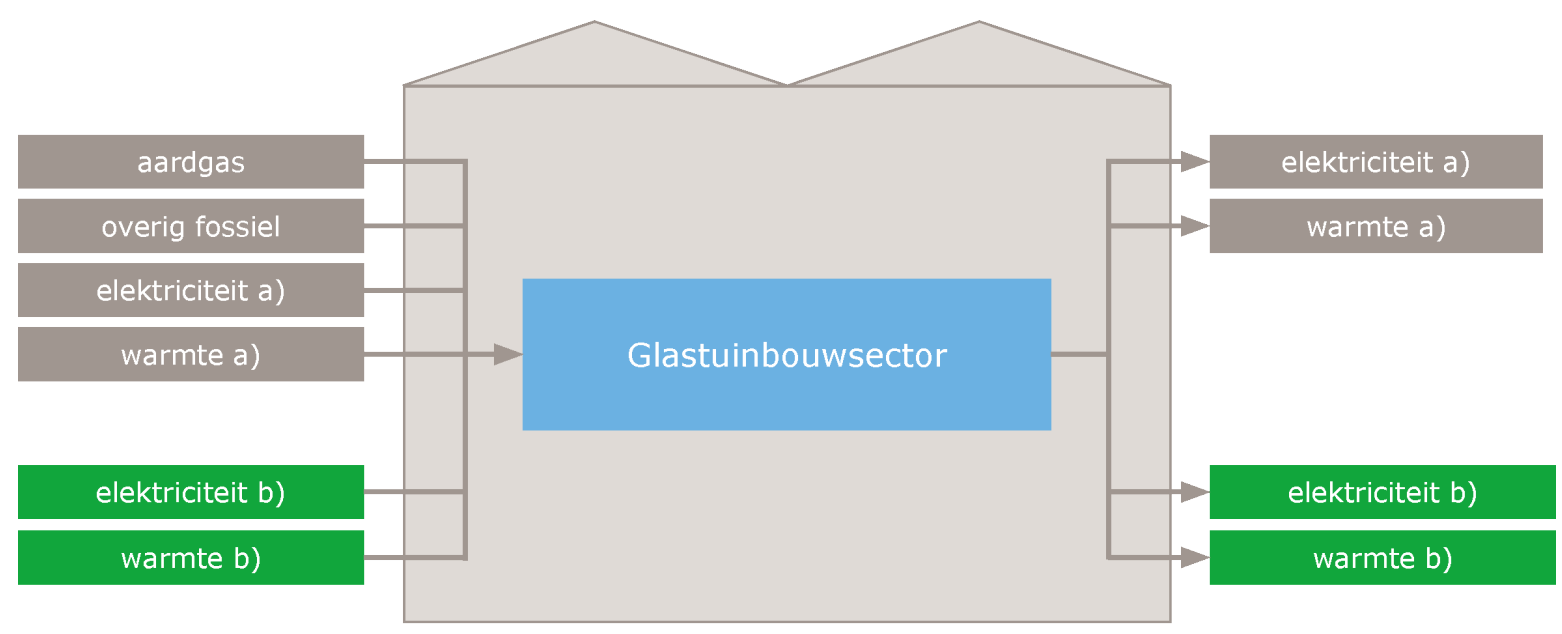

Figuur B1.2 Energie-input en -output van de glastuinbouwsector

a) Van fossiele oorsprong.

b) Uit hernieuwbare of duurzame bronnen.

\section{Duurzame energie}

Duurzame energie omvat energie uit zon, wind, waterkracht, aardwarmte en biobrandstof via een hernieuwbaar proces. Hernieuwbaar betekent dat er geen fossiele brandstof wordt gebruikt en er netto geen $\mathrm{CO}_{2}$-emissie ontstaat. Het aandeel duurzame energie heeft betrekking op het gebruik in de glastuinbouw. Duurzaam geproduceerde energie voor gebruik buiten de sector telt niet mee. 
Voorbeelden hiervan zijn op biobrandstof gestookte wkk's, waarvan de geproduceerde elektriciteit (deels) wordt verkocht buiten de sector of aardwarmte dat wordt verkocht buiten de sector. Verkoop van duurzame energie binnen de sector telt wel mee, evenals ingekochte duurzame elektriciteit en duurzame warmte van buiten de sector.

Bij het bepalen van het totale energiegebruik in de glastuinbouw op basis van energie-inhoud telt de duurzame energie wel mee. Dit is niet het geval bij het bepalen van het primair brandstofverbruik en de $\mathrm{CO}_{2}$-emissie.

\section{Temperatuurcorrectie}

Het energiegebruik verschilt van jaar tot jaar, mede door verschillen in buitentemperatuur. Het primair brandstofverbruik, en dus ook de energie-efficiëntie, wordt hiervoor gecorrigeerd. Bij het totale energiegebruik, het aandeel duurzame energie en de $\mathrm{CO}_{2}$-emissie vindt geen temperatuurcorrectie plaats.

\section{B1.2 Methode en bronnen}

Voor het kwantificeren van de indicatoren moeten de totale energie-input en -output van de glastuinbouw en de productieglastuinbouw opgesplitst naar afzonderlijke energiesoorten worden vastgesteld (figuur B1.2). Voor de energie-efficiëntie betreft dit ook de fysieke productie. Daarnaast is informatie nodig voor het opstellen van de elektriciteitsbalans.

De belangrijkste informatiebronnen zijn:

- energieregistraties van het Milieu Project Sierteelt (MPS)

- energieregistraties van Greelinqdata

- energieregistraties van groepen tuinders en adviseurs

- energieregistraties van groentebedrijven van het Bedrijveninformatienet van het Wageningen Economic Research

- inkoop van warmte van de leveranciers

- elektrisch vermogen van en elektriciteitsproductie door wkk's van energiebedrijven en tuinders vanuit de inventarisatie door BlueTerra

- gebruiksduur van wkk van tuinders op basis van informatie van energiebedrijven, groepen tuinders en het Bedrijveninformatienet van Wageningen Economic Research

- veilingomzetten bloemen en planten van de FloraHolland en Plantion

- prijsinformatie bloemen en planten van FloraHolland

- fysieke productie vruchtgroenten van het Bedrijveninformatienet van Wageningen Economic Research, accountants, telersverenigingen, groepen tuinders en adviseurs

- areaalgegevens en informatie over het gebruik van wkk door tuinders uit de Landbouwtelling, gepubliceerd door het Centraal Bureau voor de Statistiek (CBS)

- areaalgegevens belichting vruchtgroenten van adviseurs en telersverenigingen

- verkoopinformatie duurzame elektriciteit van energiebedrijven

- informatie over aardwarmteproductie van Dutch Association Geothermal Operators (DAGO);

- leveranciers van installaties en adviseurs.

\section{Energie-input en -output}

Figuur B1.2 geeft de energie-input en -output van de glastuinbouw schematisch weer. MPS, Greelinqdata en andere bronnen bieden informatie over het energiegebruik per energiesoort in de subsectoren groente, bloemen, potplanten en uitgangsmateriaal. De bedrijfsgegevens van deze bronnen zijn ingedeeld naar gewas(groep) conform de Landbouwtelling van het CBS. Met behulp van de areaalgegevens per gewas(groep) van de Landbouwtelling is de energie-informatie per gewas(groep) geaggregeerd naar sectorniveau. Daarnaast is informatie beschikbaar over de warmteinkoop door de glastuinbouw. 


\section{Wkk en elektriciteitsbalans}

De glastuinbouw produceert op grote schaal elektriciteit met wkk. De elektriciteitsproductie van deze installaties is het product van het totaal elektrisch vermogen in de glastuinbouw en de gemiddelde gebruiksduur.

Voor het in kaart brengen van een elektriciteitsbalans zijn de inkoop, verkoop en productie gekwantificeerd, waarna de elektriciteitsconsumptie is berekend. Bij dit laatste dient opgemerkt te worden dat de consumptie de sluitpost is waarin alle eventuele fouten bij het bepalen van de inkoop, verkoop en productie doorwerken. De informatie over de consumptie moet daardoor gezien worden als een globale indicatie.

\section{Inventarisatie duurzame energie}

Statistieken over het gebruik van duurzame energiebronnen zijn nog nauwelijks beschikbaar. Duurzame energie is in kaart gebracht middels een inventarisatie van de projecten. Voor inkoop duurzame elektriciteit is informatie verzameld over de verkoop aan de glastuinbouw bij energiebedrijven. Voor aardwarmte is gebruik gemaakt van informatie van DAGO.

\section{Fysieke productie}

De glastuinbouw brengt vele producten voort. De fysieke productie wordt uitgedrukt in verschillende eenheden: tomaten en paprika per kg, komkommers per stuk, bloemen per stuk of per bos en potplanten per stuk. Sommatie van deze eenheden vindt indirect plaats. Hierbij wordt uitgegaan van de totale omzet aan glastuinbouwproducten per jaar. Omzetverschillen tussen jaren hangen samen met mutaties in prijs en in fysieke productie. De fysieke productie wordt bepaald door de jaaromzet te corrigeren voor de gemiddelde prijsmutatie van de glastuinbouwproducten.

Bij de groente is beperkte informatie beschikbaar over jaaromzet en prijsmutaties. Daarom is voor deze subsector informatie over de ontwikkeling van de fysieke productie verzameld van de belangrijkste gewassen (tomaat, paprika en komkommer). Deze gewassen omvatten het overgrote deel van het areaal groente. 


\section{Bijlage 2 Kenmerken en energie-indicatoren glastuinbouw}

\begin{tabular}{|c|c|c|c|c|c|c|c|c|c|c|c|c|}
\hline Grootheid & Eenheid & 1980 & 1990 & 2000 & 2005 & 2010 & 2015 & 2016 & 2017 & 2018 & 2019 & $2020 \mathrm{v})$ \\
\hline areaal a) & $\mathrm{Ha}$ & 8.755 & 9.768 & 10.528 & 10.537 & 10.307 & 9.209 & 9.281 & 9.080 & 8.990 & 9.688 & 10.078 \\
\hline areaal b) & $\mathrm{Ha}$ & 8.527 & 9.368 & 10.036 & 10.028 & 9.757 & 8.612 & 8.638 & 8.430 & 8.380 & 8.928 & 9.349 \\
\hline buitentemperatuur c) & graaddagen (ongewogen) & 3.246 & 2.680 & 2.659 & 2.765 & 3.321 & 2.686 & 2.785 & 2.647 & 2.604 & 2.618 & 2.456 \\
\hline lichtsom d) & $\%$ & 95 & 105 & 97 & 107 & 108 & 111 & 108 & 106 & 118 & 114 & 117 \\
\hline \multirow[t]{2}{*}{ totaal energie a) e) } & PJ & - & - & 136,7 & 128,1 & 127,1 & 99,4 & 100,4 & 101,1 & 100,8 & 106,1 & 110,1 \\
\hline & GJ per $\mathrm{m}^{2}$ & - & - & 1,30 & 1,22 & 1,23 & 1,08 & 1,08 & 1,11 & 1,12 & 1,09 & 1,09 \\
\hline \multirow[t]{2}{*}{ primair brandstof $b$ ) f) } & miljard $\mathrm{m}^{3}$ a.e. & 3,49 & 4,20 & 4,28 & 3,86 & 2,56 & 2,39 & 2,44 & 2,42 & 2,47 & 2,68 & 2,82 \\
\hline & $\mathrm{m}^{3}$ a.e. per $\mathrm{m}^{2}$ & 40,9 & 44,8 & 42,6 & 38,5 & 26,3 & 27,8 & 28,3 & 28,7 & 29,5 & 30,0 & 30,2 \\
\hline fysieke productie b) & $\% 1990$ & - & 100 & 114 & 128 & 137 & 147 & 148 & 153 & 151 & 141 & 136 \\
\hline energie-efficiëntie b) f) & $\% 1990$ & - & 100 & 84 & 67 & 43 & 42 & 43 & 42 & 44 & 48 & 50 \\
\hline \multirow[t]{2}{*}{ fossiel brandstof totaal a) e) } & miljard $\mathrm{m}^{3}$ a.e. & - & 3,81 & 3,71 & 3,60 & 4,50 & 3,21 & 3,17 & 3,21 & 3,18 & 3,28 & 3,40 \\
\hline & $\mathrm{m}^{3}$ a.e. per $\mathrm{m}^{2}$ & - & 39,0 & 35,2 & 34,1 & 43,7 & 34,9 & 34,2 & 35,4 & 35,3 & 33,9 & 33,8 \\
\hline \multirow[t]{2}{*}{ fossiel brandstof teelt a) e) } & miljard $\mathrm{m}^{3}$ a.e. & - & 3,81 & 3,67 & 3,40 & 3,23 & 2,42 & 2,42 & 2,40 & 2,35 & 2,40 & 2,47 \\
\hline & $\mathrm{m}^{3}$ a.e. per $\mathrm{m}^{2}$ & - & 39,0 & 34,9 & 32,3 & 31,3 & 26,3 & 26,1 & 26,4 & 26,2 & 24,8 & 24,6 \\
\hline \multirow[t]{3}{*}{$\mathrm{CO}_{2}$-emissie totaal a) e) } & Mton & - & 6,8 & 6,7 & 6,5 & 8,1 & 5,7 & 5,7 & 5,7 & 5,7 & 5,9 & 6,1 \\
\hline & $\% 1990$ & - & 100 & 97 & 94 & 118 & 84 & 83 & 84 & 83 & 86 & 89 \\
\hline & $\mathrm{kg}$ per $\mathrm{m}^{2}$ & - & 70,0 & 63,2 & 61,2 & 78,1 & 62,3 & 61,0 & 63,3 & 63,2 & 60,6 & 60,2 \\
\hline $\mathrm{CO}_{2}$-emissie totaal a) f) & Mton & - & 7,4 & 7,3 & 6,6 & 7,8 & 5,8 & 5,7 & 5,9 & 5,8 & 6,0 & 6,3 \\
\hline $\mathrm{CO}_{2}$-emissie teelt a) e) & Mton & - & 6,8 & 6,6 & 6,1 & 5,8 & 4,3 & 4,3 & 4,3 & 4,2 & 4,3 & 4,4 \\
\hline \multirow[t]{3}{*}{$\mathrm{CO}_{2}$-emissie teelt a) f) } & Mton & - & 7,4 & 7,2 & 6,3 & 5,5 & 4,4 & 4,4 & 4,4 & 4,3 & 4,4 & 4,6 \\
\hline & $\% 1990$ & - & 100 & 97 & 85 & 74 & 60 & 59 & 59 & 58 & 59 & 62 \\
\hline & $\mathrm{kg}$ per $\mathrm{m}^{2}$ & - & 75,8 & 68,2 & 59,7 & 53,4 & 48,1 & 47,1 & 48,4 & 48,0 & 45,4 & 45,7 \\
\hline \multirow[t]{2}{*}{$\mathrm{CO}_{2}$-emissie Nederland g) } & Mton & - & 162,7 & 171,6 & 177,4 & 182,0 & 164,7 & 165,4 & 163,1 & 159,5 & 153,6 & 138,1 \\
\hline & $\% 1990$ & - & 100 & 105 & 103 & 103 & 90 & 100 & 99 & 98 & 96 & 90 \\
\hline Aandeel duurzame energie a) e) & $\%$ & - & 0,0 & 0,1 & 0,5 & 1,9 & 4,9 & 5,4 & 6,6 & 7,4 & 9,5 & 10,4 \\
\hline Aandeel duurzame energie Nederland g) & $\%$ & - & 1,2 & 1,6 & 2,5 & 3,9 & 5,8 & 6,0 & 6,6 & 7,3 & 8,8 & 11,1 \\
\hline
\end{tabular}


Bijlage 3 Energiegebruik glastuinbouw (totaal glastuinbouwareaal en niet gecorrigeerd voor temperatuur) a)

\begin{tabular}{|c|c|c|c|c|c|c|c|c|c|c|c|c|}
\hline energiesoort & eenheid & 1980 & 1990 & 2000 & 2005 & 2010 & 2015 & 2016 & 2017 & 2018 & 2019 & $2020 \mathrm{v}$ ) \\
\hline totaal fossiel & miljard $\mathrm{m}^{3}$ a.e. & - & 3,808 & 3,710 & 3,596 & 4,502 & 3,213 & 3,172 & 3,214 & 3,175 & 3,282 & 3,403 \\
\hline . waarvan aardgas & miljard $\mathrm{m}^{3}$ & 3,352 & 3,778 & 3,709 & 3,593 & 4,500 & 3,212 & 3,171 & 3,213 & 3,174 & 3,281 & 3,402 \\
\hline . waarvan overig fossiel b) & miljard $\mathrm{m}^{3}$ a.e. & - & 0,030 & 0,001 & 0,003 & 0,002 & 0,001 & 0,001 & 0,001 & 0,001 & 0,001 & 0,001 \\
\hline inkoop niet-duurzame warmte & PJ & - & 1,9 & 14,9 & 9,1 & 5,3 & 3,5 & 3,7 & 3,7 & 3,4 & 2,8 & 2,2 \\
\hline inkoop elektriciteit & TWh & - & - & 1,479 & 2,626 & 2,169 & 2,507 & 2,699 & 2,849 & 2,937 & 3,274 & 3,308 \\
\hline waarvan groen & TWh & - & - & 0,000 & 0,052 & 0,166 & 0,196 & 0,242 & 0,492 & 0,373 & 0,341 & 0,204 \\
\hline verkoop elektriciteit & TWh & - & - & 0,221 & 1,241 & 8,189 & 5,085 & 4,771 & 5,145 & 5,244 & 5,844 & 6,142 \\
\hline waarvan groen & TWh & - & - & 0,000 & 0,000 & 0,021 & 0,028 & 0,028 & 0,027 & 0,033 & 0,037 & 0,043 \\
\hline netto elektriciteit & TWh & - & - & 1,031 & 1,062 & $-6,346$ & $-2,794$ & $-2,258$ & $-2,467$ & $-2,439$ & $-2,784$ & $-3,055$ \\
\hline duurzame energie & PJ & - & - & 0,1 & 0,6 & 2,4 & 4,9 & 5,4 & 6,7 & 7,4 & 10,0 & 11,5 \\
\hline totaal energie & PJ & - & - & 136,7 & 128,1 & 127,1 & 99,4 & 100,4 & 101,1 & 100,8 & 106,1 & 110,1 \\
\hline
\end{tabular}

a) vanwege beperkte hoeveelheid en mogelijke herleidbaarheid exclusief verkoop van warmte aan afnemers buiten de sector, b) olie, diesel en propaan, - cijfers niet beschikbaar, v) cijfers 2020 voorlopig. 


\section{Bijlage 4 Gebruik en $\mathrm{CO}_{2}$-emissiereductie per duurzame energiebron}

\begin{tabular}{|c|c|c|c|c|c|c|c|c|c|c|c|c|c|c|}
\hline \multirow[t]{3}{*}{ duurzame energievorm } & \multirow{2}{*}{\multicolumn{6}{|c|}{ aantal bedrijven, areaal of hoeveelheid b) }} & \multicolumn{8}{|c|}{$\mathrm{CO}_{2}$-emissiereductie (Mton) } \\
\hline & & & & & & & \multicolumn{4}{|c|}{ sector / IPCC } & \multicolumn{4}{|c|}{ nationaal / primair brandstof } \\
\hline & Eenheid & 2010 & 2015 & 2018 & 2019 & 2020v) & 2010 & 2018 & 2019 & 2020v) & 2010 & 2018 & 2019 & $2020 v)$ \\
\hline \multirow[t]{2}{*}{ aardwarmte } & Bedrijven & 1 & 34 & 81 & 85 & 85 & \multirow[t]{2}{*}{0,02} & \multirow[t]{2}{*}{0,19} & \multirow[t]{2}{*}{0,23} & \multirow[t]{2}{*}{0,23} & \multirow[t]{2}{*}{0,01} & \multirow[t]{2}{*}{0,18} & \multirow[t]{2}{*}{0,20} & \multirow[t]{2}{*}{0,23} \\
\hline & $\mathrm{Ha}$ & 21 & 459 & 741 & 943 & 964 & & & & & & & & \\
\hline \multirow[t]{2}{*}{ biobrandstof warmte } & Bedrijven & 22 & 28 & 35 & 37 & 45 & \multirow[t]{2}{*}{0,01} & \multirow[t]{2}{*}{0,03} & \multirow[t]{2}{*}{0,05} & \multirow[t]{2}{*}{0,07} & \multirow[t]{2}{*}{0,01} & \multirow[t]{2}{*}{0,03} & \multirow[t]{2}{*}{0,05} & \multirow[t]{2}{*}{0,07} \\
\hline & $\mathrm{Ha}$ & 80 & 117 & 150 & 163 & 371 & & & & & & & & \\
\hline \multirow[t]{2}{*}{ biobrandstof warmte en elektriciteit } & Bedrijven & 4 & 4 & 6 & 6 & 6 & \multirow[t]{2}{*}{0,01} & \multirow[t]{2}{*}{0,01} & \multirow[t]{2}{*}{0,01} & \multirow[t]{2}{*}{0,01} & \multirow[t]{2}{*}{0,02} & \multirow[t]{2}{*}{0,03} & \multirow[t]{2}{*}{0,02} & \multirow[t]{2}{*}{0,01} \\
\hline & ha] & 45 & 19 & 45 & 45 & 45 & & & & & & & & \\
\hline zonnewarmte & Bedrijven & 55 & 64 & 62 & 62 & 61 & 0,04 & 0,04 & 0,04 & 0,04 & 0,01 & 0,02 & 0,02 & 0,02 \\
\hline & ha a) & 216 & 211 & 214 & 214 & 212 & & & & & & & & \\
\hline zonne-elektriciteit & Bedrijven & 1 & 3 & 62 & 101 & 147 & 0,00 & 0,00 & 0,00 & 0,00 & 0,00 & 0,01 & 0,01 & 0,01 \\
\hline & $\mathrm{Ha}$ & 8 & 65 & 257 & 358 & 459 & & & & & & & & \\
\hline inkoop duurzame elektriciteit & TWh & 0,18 & 0,20 & 0,40 & 0,37 & 0,22 & 0,00 & 0,00 & 0,00 & 0,00 & 0,08 & 0,17 & 0,16 & 0,09 \\
\hline inkoop duurzame warmte (centraal) & - & - & - & - & - & - & 0,01 & 0,01 & 0,04 & 0,06 & 0,01 & 0,01 & 0,04 & 0,06 \\
\hline inkoop duurzame warmte (lokaal) & Bedrijven & 6 & 7 & 9 & 64 & 87 & 0,01 & 0,03 & 0,10 & 0,17 & 0,01 & 0,03 & 0,10 & 0,16 \\
\hline & $\mathrm{Ha}$ & 30 & 33 & 68 & 421 & 950 & & & & & & & & \\
\hline inkoop duurzaam gas & miljoen $\mathrm{m}^{3}$ a.e. & 1 & 1 & 1 & 1 & 1 & 0,00 & 0,00 & 0,00 & 0,00 & 0,00 & 0,00 & 0,00 & 0,00 \\
\hline Totaal & & & & & & & 0,10 & 0,33 & 0,47 & 0,58 & 0,16 & 0,47 & 0,59 & 0,65 \\
\hline
\end{tabular}

a) het vermelde areaal is het areaal waarop de toepassing van herwonnen zonnewarmte plaatsvindt, b) peildatum eind 2020, - cijfers niet beschikbaar, v) cijfers 2020 voorlopig. 
Bijlage 5 Inkoop externe $\mathrm{CO}_{2}$, gebruik en $\mathrm{CO}_{2}$-emissiereductie wkk en inkoop van warmte

\begin{tabular}{|c|c|c|c|c|c|c|c|c|c|c|c|c|c|c|}
\hline \multirow[t]{3}{*}{ duurzame energievorm } & \multirow{2}{*}{\multicolumn{6}{|c|}{ areaal of vermogen }} & \multicolumn{8}{|c|}{$\mathrm{CO}_{2}$-emissiereductie (Mton) } \\
\hline & & & & & & & \multicolumn{4}{|c|}{ sector / IPCC } & \multicolumn{4}{|c|}{ nationaal / primair brandstof } \\
\hline & Eenheid & 2010 & 2015 & 2018 & 2019 & 2020 & 2010 & 2018 & 2019 & 2020 & 2010 & 2018 & 2019 & 2020 \\
\hline inkoop externe $\mathrm{CO}_{2}$ & Mton & $0,51-0,54$ & $0,51-0,55$ & $0,65-0,69$ & $0,69-0,73$ & $0,65-0,69$ & $\#$ & $\#$ & $\#$ & $\#$ & $\#$ & $\#$ & $\#$ & $\#$ \\
\hline wkk glastuinbouw & $M W_{\text {el }}$ & 2.308 & 2.396 & 2.424 & 2.546 & 2.534 & $-2,60$ & $-2,58$ & $-2,81$ & $-2,78$ & 1,88 & 1,54 & 1,59 & 1,57 \\
\hline wkk energiebedrijven & $M W_{\text {el }}$ & 114 & 23 & 10 & 0 & 0 & 0,09 & 0,00 & 0,00 & 0,00 & 0,06 & 0,00 & 0,00 & 0,00 \\
\hline inkoop niet-duurzame warmte (centraal) & $\mathrm{Ha}$ & $430-450$ & $470-489$ & $470-490$ & $480-500$ & $480-500$ & 0,20 & 0,18 & 0,15 & 0,12 & 0,14 & 0,14 & 0,12 & 0,09 \\
\hline Totaal & & & & & & & $-2,31$ & $-2,40$ & $-2,66$ & $-2,66$ & 2,08 & 1,69 & 1,70 & 1,66 \\
\hline
\end{tabular}

\# niet gekwantificeerd, v) cijfers 2020 voorlopig. 


\section{Bijlage 6 Effecten aanpassingen areaal CBS Landbouwtelling op de Energiemonitor}

\section{Definitie areaal glastuinbouw}

- In de Meerjarenafspraak Energietransitie Glastuinbouw en in het Protocol van de Energiemonitor van de Nederlandse glastuinbouw is de sector glastuinbouw gedefinieerd als het areaal glastuinbouw in de Landbouwtelling (LBT) van het Centraal Bureau voor de Statistiek (CBS). Voor de Energiemonitor wordt daardoor uitgegaan van het areaal in de LBT, zowel totaal in Nederland als per gewas(groep).

\section{Landbouwtellingen 2019 en 2020}

- In 2019 is het areaal glastuinbouw in de LBT met zo'n 8\% toegenomen, in 2020 was de toename circa 4\% (figuur B2.1). De totale areaalmutatie was niet proportioneel verdeeld over de afzonderlijke gewassen.

- Vanuit de beschikbare inzichten zijn deze areaalmutaties maar voor een deel het gevolg van de werkelijke fysieke wijzigingen (het saldo van nieuwbouw, sloop en bestemmingswijziging).

- De LBT omvat bedrijven/vestigingen die de LBT in de 'Gecombineerde Opgave' hebben ingevuld en bedrijven/vestigingen die door het CBS zijn bijgeschat. Uit nadere analyse van de data blijkt dat in 2019 en 2020 meer bedrijven/vestigingen de LBT hebben ingevuld en minder bedrijven/vestigingen zijn bijgeschat. Per saldo blijkt dat in 2019 en 2020 meer bedrijven/vestigingen deel uit maken van de LBT en het areaal groter is dan in de jaren hiervoor.

- Door het voorgaande is het aannemelijk dat de LBT in eerdere jaren een te laag areaal gaf en in 2019 en 2020 dichter bij de werkelijkheid zit.

- Op de vraag of de LBT in 2020 het complete areaal glastuinbouw in Nederland omvat, bestaat geen antwoord.

\section{Effecten op de Energiemonitor Glastuinbouw}

- In combinatie met de bottom-up benadering voor het bepalen van het energiegebruik op sectorniveau in de methodiek van de Energiemonitor glastuinbouw (zie Protocol) brengt het grotere areaal in 2019 en 2020 met zich mee dat het totaal energiegebruik, het aardgasverbruik, de verkoop en inkoop elektriciteit, het wkk-vermogen en daarmee de elektriciteitsproductie op sectorniveau toeneemt. Naast het totaal areaal is ook het areaal per gewas(-groep) van invloed.

- De energie-efficiëntie wordt berekend door het primair brandstofverbruik per $\mathrm{m}^{2}$ te delen door de fysieke productie per $\mathrm{m}^{2}$ (zie Protocol).

- Door de bottom-up benadering bij het bepalen van het energiegebruik wordt het primair brandstofverbruik per $\mathrm{m}^{2}$ niet beïnvloed door de toename van het areaal.

- De fysieke productie per $\mathrm{m}^{2}$ wordt voor de sierteelt (bloemen en planten) top-down berekend (zie Protocol). De totale fysieke productie wordt hierbij gedeeld door het areaal. Hierdoor wordt de fysieke productie per $\mathrm{m}^{2}$ wel beïnvloed door de toename van het areaal. Bij voedingstuinbouw (groente en fruit) wordt de fysieke productie bottom-up bepaald (zie Protocol) waardoor dit niet beïnvloed wordt door het totaal areaal; eventueel wel door het areaal per gewas(groep). Hierdoor daalt per saldo de fysieke productie per $\mathrm{m}^{2}$ en verslechterd de energie-efficiëntie.

- De toename van het areaal heeft geen invloed op het gebruik van duurzame energie en inkoop van warmte van buiten de sector. Deze worden beiden bepaald met een inventarisatie op projectniveau en daarop heeft het areaal geen invloed.

\section{Effecten op $\mathrm{CO}_{2}$-emissie van de glastuinbouw}

- Door de toename van het areaal neemt het totaal aardgasverbruik en dus de $\mathrm{CO}_{2}$-emissie toe.

- Door mutaties van het areaal per gewas (structuur effect) ontstaat er op sectorniveau intensivering en extensivering. Hierdoor wijzigt het gemiddeld energiegebruik per $\mathrm{m}^{2}$. Ook dit is van invloed op de $\mathrm{CO}_{2}$-emissie. De verhouding van de areaalmutatie per gewas(-groep) verschilt tussen 2018 en 2019 en tussen 2019 en 2020. 
- Naast het directe effect van het areaal zijn er ook indirecte effecten. Door de toename van het areaal neemt ook de in- en verkoop van elektriciteit toe. Door het eerste neemt de $\mathrm{CO}_{2}$-emissie af en door het tweede neemt de $\mathrm{CO}_{2}$-emissie toe.

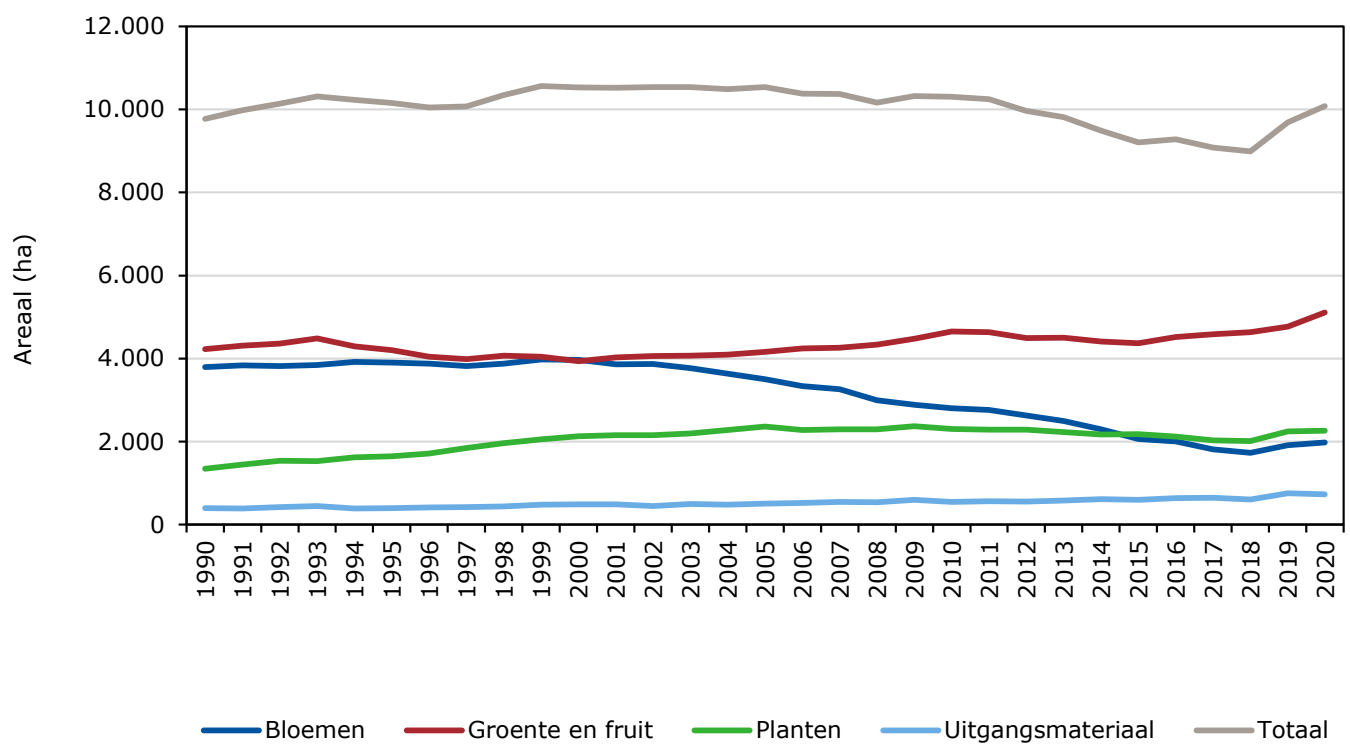

Figuur B6.1 Ontwikkeling areaal glastuinbouw in de Landbouwtelling, totaal en per subsector a) a) bron: $C B S$. 
Wageningen Economic Research Postbus 29703

2502 LS Den Haag

T 0703358330

Ecommunications.ssg@wur.nl

www.wur.nl/economic-research

Wageningen Economic Research RAPPORT

2021-127
De missie van Wageningen University \& Research is 'To explore the potential of nature to improve the quality of life'. Binnen Wageningen University \& Research bundelen Wageningen University en gespecialiseerde onderzoeksinstituten van Stichting Wageningen Research hun krachten om bij te dragen aan de oplossing van belangrijke vragen in het domein van gezonde voeding en leefomgeving. Met ongeveer 30 vestigingen, 6.800 medewerkers $(6.000 \mathrm{fte})$ en 12.900 studenten behoort Wageningen University \& Research wereldwijd tot de aansprekende kennisinstellingen binnen haar domein. De integrale benadering van de vraagstukken en de samenwerking tussen verschillende disciplines vormen het hart van de unieke Wageningen aanpak. 



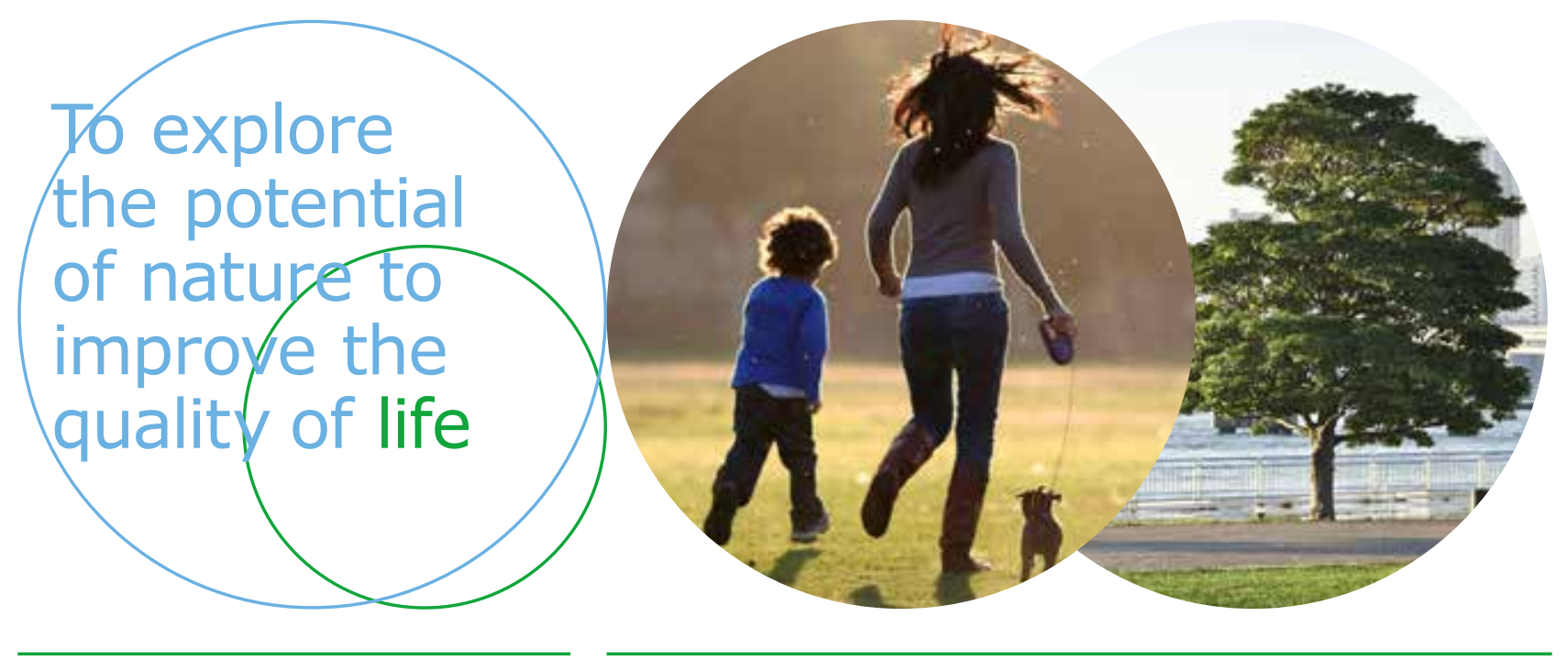

Wageningen Economic Research Postbus 29703

2502 LS Den Haag

T 0703358330

E communications.ssg@wur.nl www.wur.nl/economic-research

Rapport 2021-127

ISBN 978-94-6447-000-0
De missie van Wageningen University \& Research is 'To explore the potential of nature to improve the quality of life'. Binnen Wageningen University \& Research bundelen Wageningen University en gespecialiseerde onderzoeksinstituten van Stichting Wageningen Research hun krachten om bij te dragen aan de oplossing van belangrijke vragen in het domein van gezonde voeding en leefomgeving. Met ongeveer 30 vestigingen, 6.800 medewerkers ( $6.000 \mathrm{fte}$ ) en 12.900 studenten behoort Wageningen University \& Research wereldwijd tot de aansprekende kennisinstellingen binnen haar domein. De integrale benadering van de vraagstukken en de samenwerking tussen verschillende disciplines vormen het hart van de unieke Wageningen aanpak. 